\title{
The Geothermal Hydrology of Warner Valley, Oregon: A Reconnaissance Study
}

By EDWARD A. SAMMEL and ROBERT W. CRA.IG

GEOHYDROLOGY OF GEOTHERMAL SYSTEMS

GEOLOGICAL SURVEY PROFESIONAL PAPER 1044-I

A description and evaluation of a

moderate-temperature hydrothermal convection system

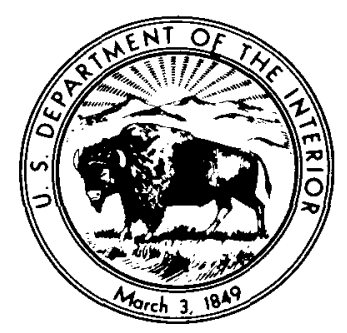

MOTICE

PORTIONS OF THIS REPORT ARE HLEEIBLE.

It has been reproduces ${ }^{2}$ oth the best available copy to permit the broadest possible availability.

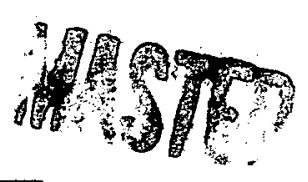

UNITED STATES GOVERNMENT PRINTING OFFICE, WASHINGTON: 1981

DISTRBDUTION OF THIS BOCUMENT IS UNLMMIED

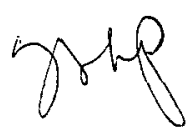




\section{DISCLAIMER}

This report was prepared as an account of work sponsored by an agency of the United States Government. Neither the United States Government nor any agency Thereof, nor any of their employees, makes any warranty, express or implied, or assumes any legal liability or responsibility for the accuracy, completeness, or usefulness of any information, apparatus, product, or process disclosed, or represents that its use would not infringe privately owned rights. Reference herein to any specific commercial product, process, or service by trade name, trademark, manufacturer, or otherwise does not necessarily constitute or imply its endorsement, recommendation, or favoring by the United States Government or any agency thereof. The views and opinions of authors expressed herein do not necessarily state or reflect those of the United States Government or any agency thereof. 


\section{DISCLAIMER}

Portions of this document may be illegible in electronic image products. Images are produced from the best available original document. 


\section{UNITED STATES DEPARTMENT OF THE INTERIOR JAMES G. WATT, Secretary}

\section{GEOLOGICAL SURVEY}

Dallas L. Peck, Director

Library of Congress Cataloging in Publication Data

Samme 1, Edward A.

The geothermal hydrology of Warner Valley, Oregon.

(Geohydrology of geothermal systems) (Geological

Survey Professional Paper 1044-I)

Bibliography: p. I45-147.

Supt. of Docs. no.: I 19.2:0r3/5

1. Geothermal resources--Oregon--Warner Valley. 2. Water, Underground--Oregon--Warner Valley. I. Craig, Robert W. II. Title. III. Series. IV. Series: Geological Survey Professional Paper 1044-I. GB1199.7.07S24 553.7 


\section{CONTENTS}

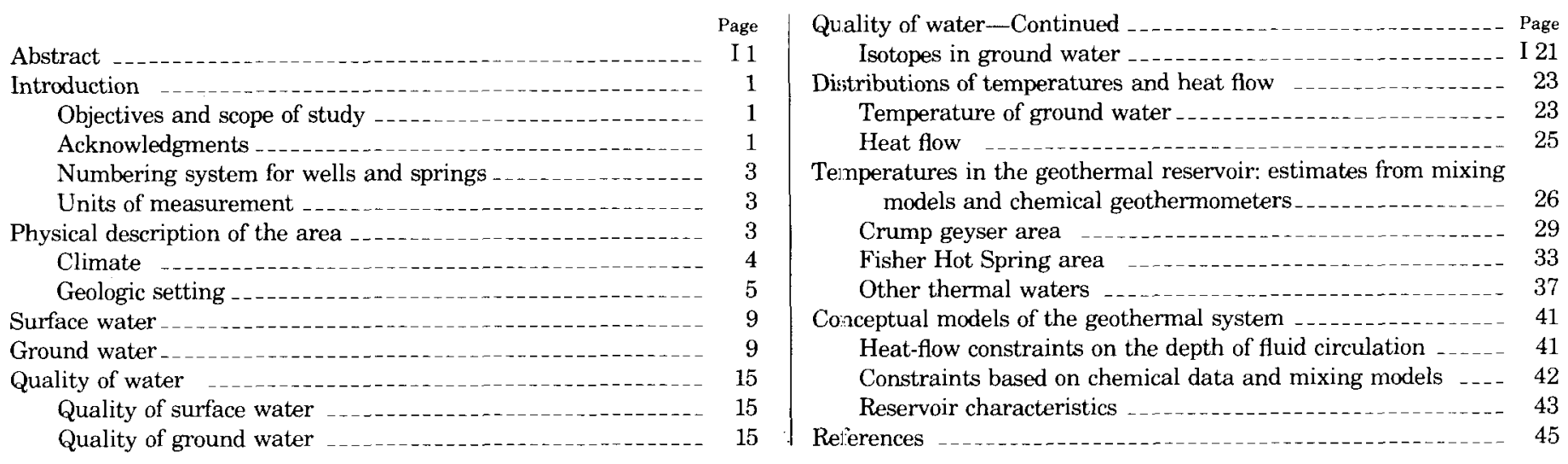

\section{ILLUSTRATIONS}

PLATE 1. Map showing locations of springs, wells, and heat-flow holes, and. Stiff diagrams for water sampled for chemical analysis--- In pocket

Figure 1. Index map of the Warner Valley area, Oregon

2. Subdivision of township and range sections for well-numbering siystem

3. Geologic map of the Warner Valley area

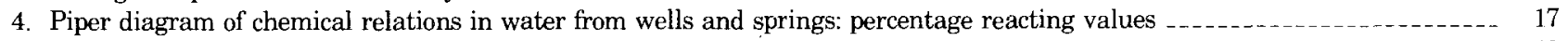

5. Graph of chloride concentration versus fluoride concentration in ground water

6. Graph of chloride concentration versus temperature in ground water

7. Graph of chloride concentration versus silica concentration in ground water and hypothetical reservoir water $\ldots$

8. Graph of the weight ratio $\left(\mathrm{Cl} / \mathrm{SiO}_{2}\right)$ versus chloride concentration in ground water

9. Graph of the weight ratio $\left(\mathrm{Cl} / \mathrm{HCO}_{3}\right)$ versus chloride concentration in ground water

10. Graph of $\delta^{18} \mathrm{O}$ versus $\delta \mathrm{D}$ in ground water as departures, in part; per thousand, from standard mean ocean water

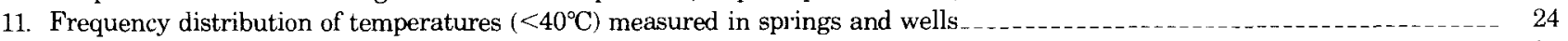

12. Profiles of temperature measured in heat-flow holes

13. Profiles of temperature measured in water wells

14. Map of the Crump geyser area, showing temperatures measured and estimated at a depth of 2 meters below land surface $\ldots$

15. Graph showing correlation between temperatures estimated by the silica and Na-K-Ca geothermometers _............. 28

16. Graph of silica concentration versus enthalpy in waters having surface temperatures $>30^{\circ} \mathrm{C}$

17. Graph of chloride concentration versus enthalpy in waters having surface temperatures $>30^{\circ} \mathrm{C}$

18. Graph of boron concentration versus enthalpy in waters having surface temperatures $>30^{\circ} \mathrm{C}$

19. Graph of chloride concentration versus $\delta \mathrm{D}$ in ground water, showing a single-stage boiling curve between $220^{\circ} \mathrm{C}$ and $96^{\circ} \mathrm{C} \quad--36$

20. Graph of chloride concentration versus $\delta^{18} \mathrm{O}$ in ground water, showing a single-stage boiling curve between $220^{\circ} \mathrm{C}$ and $96^{\circ} \mathrm{C}$-- 36

21. Hypothetical profile of normal temperature versus depth in Warner Valley

\section{TABLES}

TABLE 1. Annual precipitation and temperature at three U.S. Weather Service stations in and near Warner Valley for the period $1963-77$--

2. Average annual streamflow entering Warner Valley in Deep Creek, Honey Creek, and Twentymile Creek for the period of record prior to 1976

3. Data from wells and heat-flow holes 
TABLE 4. Data from selected springs Page

5. Chemical analyses of surface water

6. Chemical analyses of water from wells and springs

7. Molal ratios of selected dissolved constituents in ground water

8. Isotopes of oxygen $\left({ }^{18} \mathrm{O}\right)$ and hydrogen (deuterium and tritium) in ground water.

9. Calculated temperatures of equilibration for waters having surface temperatures of $20^{\circ} \mathrm{C}$ or more

\section{CONVERSION OF UNITS OF MEASUREMENT}

Used in

this report
Multiply by

Length

inch (in)

foot ( $\mathrm{ft}$ )

mile (mi)

square foot $\left(\mathrm{ft}^{2}\right)$

acre

square mile $\left(\mathrm{mi}^{2}\right)$

acre-foot (acre-ft)

cubic mile $\left(\mathrm{mi}^{3}\right)$

gallon per minute (gal $\mathrm{min}^{-1}$ )

gallon per minute ( $\mathrm{gal} \mathrm{min}^{-1}$ )

kilogram per second $\left(\mathrm{kg} \mathrm{s}^{-1}\right)$

foot per day ( $\left.\mathrm{ft} \mathbf{d}^{-1}\right)$

cubic foot per day per foot $\left(\mathrm{ft}^{3} \mathrm{~d}^{-1} \mathrm{ft}^{-1}\right)$

degree Celsius $\left({ }^{\circ} \mathrm{C}\right)$

degree Celsius per kilometer $\left({ }^{\circ} \mathrm{C} \mathrm{km}^{-1}\right)$

watt per meter-kelvin $\left(\mathrm{W}(\mathrm{m} \cdot \mathrm{k})^{-1}\right)$

milliwatt per square meter $\left(\mathrm{mW} \mathrm{m}^{-2}\right)$

watt per square meter $\left(\mathrm{W} \mathrm{m}^{-2}\right)$

joule (J)

joule per second $\left(\mathrm{J} \mathrm{s}^{-1}\right)$

joule per cubic centimeter per degree Celsius $\left(\mathrm{J} \mathrm{cm}^{-3}{ }^{\circ} \mathrm{C}^{-1}\right)$

micromho per centimeter $\left(\mu \mathrm{mho} \mathrm{cm}^{-1}\right)$
25.40

0.3048

1.609

Area

0.0929

0.4048

2.590

Volume

$1.233 \times 10^{-33}$

4.168

Flow

0.06308

3.785

1.000

Permeability 0.305

Transmissivity 0.0929

Temperature

1.8 (and add 32 )

Thermal gradient 0.05486

Thermal conductivity 2.390

Heat flow 0.0239

23.90

Thermal energy

0.239

1.000

Specific heat (volumetric)

0.239

Electrical conductance 1.000
To obtain

millimeter $(\mathrm{mm})$

meter $(\mathrm{m})$

kilometer $(\mathrm{km})$

square meter $\left(\mathrm{m}^{2}\right)$

hectare (ba)

square kilometer $\left(\mathrm{km}^{2}\right)$

cubic hectometer $\left(\mathrm{hm}^{3}\right)$ cubic kilometer $\left(\mathrm{km}^{3}\right)$

liter per second $\left(\mathrm{L} \mathrm{s}^{-1}\right)$

liter per minute $\left(\mathrm{L} \mathrm{min}^{-1}\right)$

liter per second $\left(\mathrm{L} \mathrm{s}^{-1}\right)$ for pure water at $3.89^{\circ} \mathrm{C}$

meter per day $\left(\mathrm{m} \mathrm{d}^{-1}\right)$

meter squared per day $\left(\mathrm{m}^{2} \mathrm{~d}^{-1}\right)$

degree Fahrenheit $\left({ }^{\circ} \mathbf{F}\right)$

degree Fahrenheit per hundred feet $\left({ }^{\circ} \mathbf{F} /\right.$ $100 \mathrm{ft}$ )

millicalorie per centimeter per second per degree Celsius (mcal $\mathrm{cm}^{-1} \mathrm{~s}^{-10} \mathrm{C}^{-1}$ )

microcalorie per square centimeter per second

( $\mu \mathrm{cal} \mathrm{cm}^{-2} \mathrm{~s}^{-1}$ )

microcalorie per square centimeter per second

$1 \mu \mathrm{cal} \mathrm{cm} \mathrm{cm}^{-2} \mathrm{~s}^{-1}=1$ heat-flow unit (HFU)

calorie (cal)

watt $(\mathrm{W})$

calorie per cubic centimeter per degree Celsius ( $\mathrm{cal} \mathrm{cm}^{-3}{ }^{\circ} \mathrm{C}^{-1}$ )

microsiemens per centimeter $\left(\mu \mathrm{S} \mathrm{cm}^{-1}\right)$ 


\title{
THE GEOTHERMAL HYDROLOGY OF WARNER VALLEY, OREGON: A RECONNAISSANCE STUDY
}

\author{
By Edward A. Sammel and Robert W. Craig
}

\begin{abstract}
Warner Valley and its southern extension, Coleman Valley, are two of several high-desert valleys in the Basin and Range province of south-central Oregon that contain thermal waters. At least 20 thermal springs, defined as having temperatures of $20^{\circ} \mathrm{C}$ or more, issue from Tertiary basaltic flows and tuffs in and near the valleys. Many shallow wells also produce thermal waters. The highest measured temperature is $127^{\circ} \mathrm{C}$, reported from a well known as Crump geyser, at a depth of 200 meters. The hottest spring, located near Crump geyser, has a surface temperature of $78^{\circ} \mathrm{C}$. The occurrence of these thermal waters is closely related to faults and fault intersections in the graben and horst structure of the valleys.

Chemical analyses show that the thermal waters are of two types: sodium chloride and sodium bicarbonate waters. The warmer waters are likely to have higher concentrations of sodium and chloride, as well as sulfate, silica, and dissolved solids, than the cooler waters. Chemical indicators show that the geothermal system is a hot-water rather than a vapor-dominated system.

Conductive heat flow in areas of the valley unaffected by hydrothermal convection is probably about 75 milliwatts per square meter. The normal thermal gradient in valley-fill deposits in these areas may be about $40^{\circ} \mathrm{C}$ per kilometer. Extensive areas underlain by thermal ground water occur near Crump geyser and Fisher Hot Spring. These two areas, located along the western and eastern boundary faults, respectively, are believed to be zones in which hot water, derived from geothermal reservoirs, spreads from the fault zones and mixes with local ground water. Thermal gradients in the valley-fill deposits are extremely high in these areas.

Geothermometers and mixing models indicate that temperatures of equilibration are at least $170^{\circ} \mathrm{C}$ for the thermal components of the hotter waters. The thermal waters probably originate as local meteoric water which circulates to great depths in the fault zones. The depth of circulation may be as great as 4 kilometers, on the basis of the thermal gradients (about $40^{\circ} \mathrm{C}$ per kilometer) estimated for the valley-fill deposits and bedrock.

The size and location of geothermal reservoirs are unknown. If the mixing models are valid, thermal waters of the Crump geyser area and the Fisher Hot Spring area could be derived from a common reservoir. If so, a probable maximum size for such a reservoir is about 38 cubic kilometers at a depth near 4 kilometers. Total heat stored in the reservoir, above a base temperature of $10^{\circ} \mathrm{C}$, could be as much as $1.6 \times 10^{19}$ joules. A probable minimum value for stored heat, estimated on the basis of the assumption that the thermal fluids at depth are entirely restricted to the major boundary faults, may be about 5 $\times 10^{16}$ joules.
\end{abstract}

The reservoir at a depth of 4 kilometers constitutes a resource. under present economic conditions only to the extent that hot water can be withdrawn from upflow conduits at shallower depths. Because of conductive cooling, water temperatures in the upflow conduits will have lower temperatures than water in the reservoir. Recoverable heat stored in mixing zones in the valley-fill deposits at depths less than 300 meters may total at least $5 \times 10^{16}$ joules, however, and may represent an economic resource at temperatures greater than $100^{\circ} \mathrm{C}$.

\section{INTRODUCTION}

\section{OBJECTIVES AND SCOPE OF STUDY}

The objectives of the study can be summarized as follows:

1. To determine the large-scale characteristics of the hydrologic regime with emphasis on the occurrence and nature of the ground water.

2. To map the geology as it relates to the hydrologic regime.

3. To determine the chemical characteristics of the nonthermal waters of the area and their relation to the geothermal waters.

4. To interpret, if possible, the geologic and hydrologic data in terms of the nature and extent of the geothermal systems and the characteristics of the geothermal reservoirs.

The investigations described in this report were made during the fall of 1974 and the summer of 1976 . The area of study comprises about 875 square miles $\left(\mathrm{mi}^{2}\right)$ in Warner Valley, Coleman Valley, and adjacent highlands in south-central Oregon (fig. 1). Within this area, nearly all wells and springs were inventoried, all known sources of geothermal water were investigated, and most were sampled for chemical and isotope analysis.

The geologic map by Walker and Repenning (1965) provides the framework for the stratigraphy and lithology described in this report. Detailed structural mapping in much of the area was added in 1976 by $\mathrm{N}$. E. Voegtly.

\section{ACKNOWLEDGMENTS}

The authors are grateful for assistance received from many individuals and organizations. Information and 


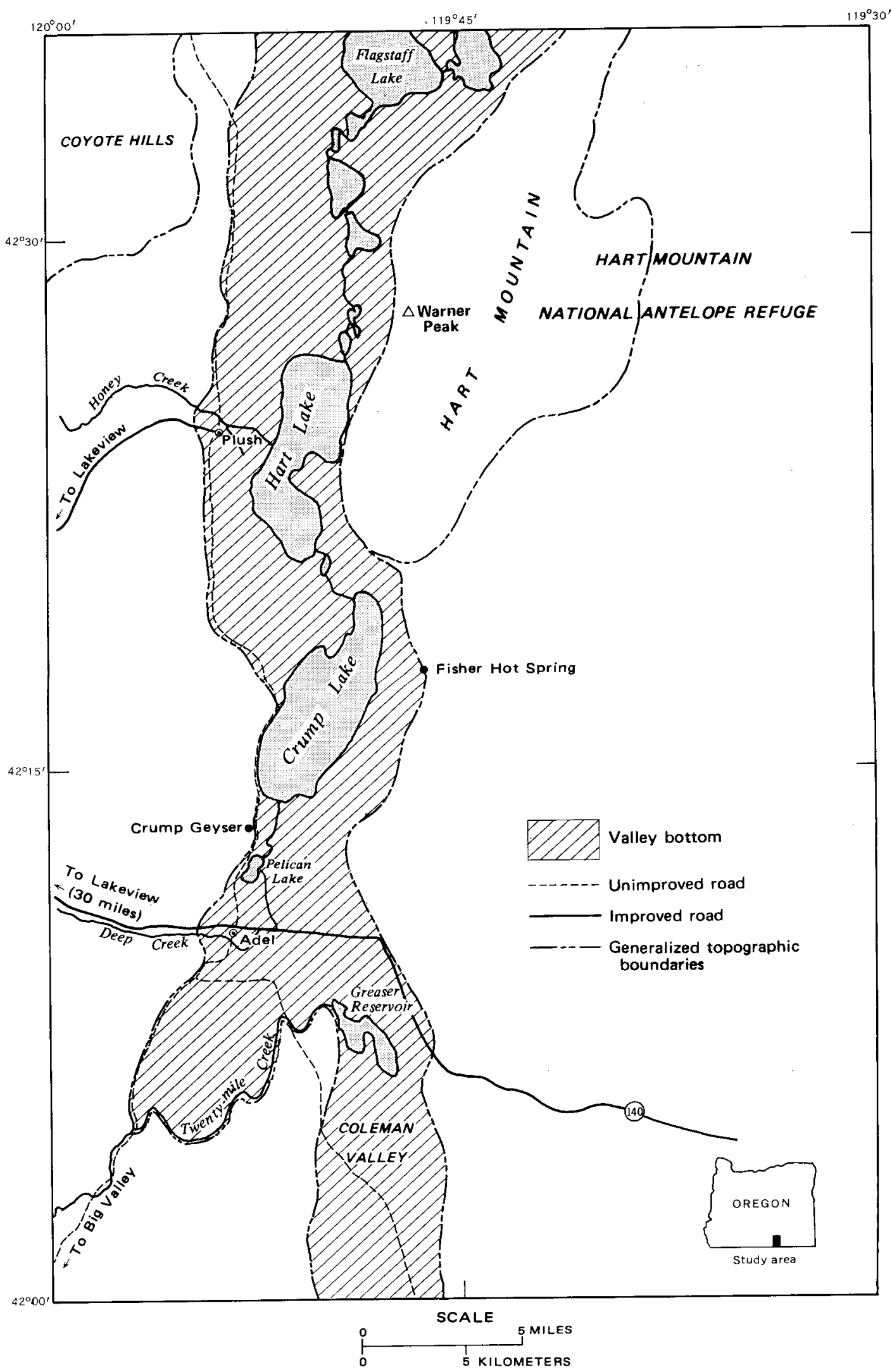

Figure 1.-Index map of the Warner Valley area, Oregon. 
facilities provided by the Lakeview District Office, U.S. Bureau of Land Management was especially helpful. Thanks are also due to the U.S. Soil Conservation Service for the use of aerial photographs, to the Geothermal Division of Gulf Oil Co. for permitting us to drill on land leased by them, and to Jack Stooksberry, Lakeview well driller, for much helpful information. Finally, we are grateful to scores of landowners who granted access to wells and springs, provided information, and cooperated in many other ways with the investigation.

\section{NUMBERING SYSTEM FOR WELLS AND SPRINGS}

In this report, wells and springs are numbered according to a system based on their locations within townships, ranges, and sections referred to the Willamette Baseline and Meridian. Thus, the number $36 / 24-4$ baaa specifies a well in Township 36 South, Range 24 East, and Section 4 . The letters which follow indicate respectively the $1 / 4,1 / 16,1 / 64$, and $1 / 256$ quadrants within the section according to the scheme illustrated in figure 2.

A number following the letters indicates that more than one well was inventoried in the same $1 / 256 \mathrm{sec}-$ tion quadrant; such wells are numbered serially in chronological order of inventory. Each well number specifies a location within a quadrant that is 330 feet on a side.

\section{UNITS OF MEASUREMENT}

The units of measurement in this report are those usied in the field or obtained from the reports of others. For the most part, these units are in the foot-pound system, and this system has been retained for the convenience of most readers. Temperatures were measured in degrees Celsius $\left({ }^{\circ} \mathrm{C}\right)$ and are consistently reported as such. Derived units are generally calculated and reported in the units obtained in the field. In the sections of the report entitled "Distributions of Temperature and Heat Flow" and "Conceptual Models of the Geothermal System," the units used for measurements of thermal gradients and heat flow are in the International System in order to avoid conversion of data obtained from others and to facilitate comparison with most published data. Units of mass and length used in these sections of the report are also given in the International System for the sake of consistency. The table, "Conversion of Units of Measurement," at the beginning of this report, will enable units to be converted from one system to the other.

\section{PHYSICAL DESCRIPTION OF THE AREA}

Warner Valley is a narrow graben about 60 miles long and 4 to 5 miles wide. It is alined approximately north-south, paralleling the Warner Range which lies some 15 miles to the west. The valley lies in a transition zone between the Great Basin and the Columbia

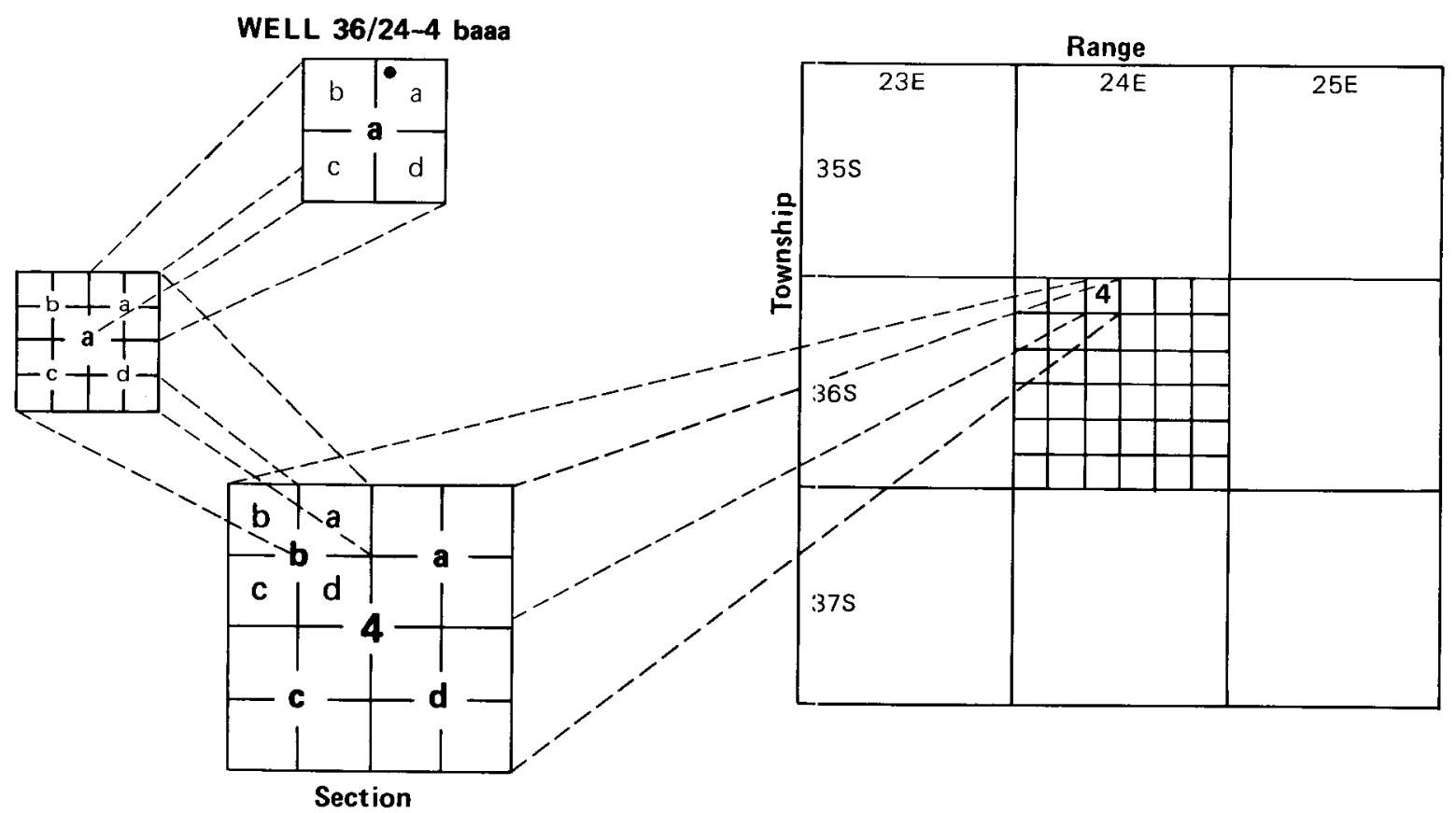

FIGURE 2.-Subdivision of township and range sections for well-numbering system. 
Plateaus physiographic provinces. It is unique among valleys in south-central Oregon in having an abundant supply of surface water, most of which is derived from precipitation on the mountains.

At the south end of Warner Valley, and separated from it by an upraised fault block, is Coleman Valley, about 10 miles long and 3 miles wide, which extends into Nevada. Unlike Warner Valley, Coleman Valley is dry most of the year and contains playa lake beds. In this respect, Coleman Valley is more typical of the high-desert valleys that occur to the south in Nevada and to the east in Oregon.

The upraised fault blocks that define the valley have precipitous slopes along most of the valley length. Maximum relief between the valley floor and the fault-block summits is about 3,560 feet and occurs between Warner Peak on Hart Mountain and the adjacent valley floor in a distance of only about 3 miles. The sunken blocks that underlie the floor of Warner Valley are covered by alluvial and lacustrine deposits that are 800 feet deep in some places and may be much deeper in at least one area. Eleven shallow lakes and many ephemeral ponds occur in the valley, fed by three perennial streams and many springs. Warner Valley and its tributary, Coleman Valley, form a closed basin with respect to surface water. It is probable, however, that ground water flows from the basin at its northern end.

Irrigated crops, principally alfalfa and some cereal grains, flourish in Warner Valley, with surface water furnishing most of the water supply in the south half of the valley and ground water supplying the north half. Thousands of cattle forage in the highlands adjacent to the valley during the summer months and are brought into the valley each fall for sale or winter feeding. The economy of the valley is almost entirely dependent on cattle ranching.

The lakes and pastures of Warner Valley provide a natural sanctuary and feeding ground for water fowl. Deer are prevalent in the higher country, and herds of pronghorn anteope occupy the barren high-desert country east of Hart Mountain. The area was probably a favored hunting ground for prehistoric Indians, and their pictographs are found on several large boulders on the east side of the valley.

At least 20 geothermal wells and springs occur in Warner and Coleman Valleys. This number is based on the assumption that any water having a temperature of $20^{\circ} \mathrm{C}$ or more has a geothermal component. With the exception of a warm spring on Hart Mountain and a slightly warm well in the valley northwest of Hart Mountain, all of the known thermal occurrences are located south of Hart Lake. The present study has been largely confined to the areas containing the known thermal waters and the adjacent highlands at the south end of the basin. A high valley, 10 miles west of the main area on the lower slopes of the Warner Range, was also studied. This area, Big Valley, contains the headwaters of Deep Creek as well as several thermal springs.

\section{CLIMATE}

The climate of Warner Valley is relatively mild because of its protected location. Average annual temperature in the valley at Adel for a recent period of 15 years is $9.4^{\circ} \mathrm{C}$, as compared with $8^{\circ} \mathrm{C}$ at Lakeview, about 30 miles west of Adel, and $6.4^{\circ} \mathrm{C}$ on Hart Mountain (table 1).

Average annual precipitation at Adel is about 9.9 inches as compared with 16.5 inches at Lakeview. Much of the precipitation brought into the region by westerly winds is apparently intercepted by the Warner Range and fails to reach the Warner Valley area. The valley would be considered semiarid were it not for the three perennial streams that flow into it from the Warner Range.

Rates of evapotranspiration in Warner Valley have not been determined. A crude estimate of total evapotranspiration may be obtained, however, from estimates of precipitation and streamflow. It seems reasonable to assume that precipitation at Adel is representative of precipitation on the valley floor south of the $42^{\circ} 30^{\prime}$ parallel. Over this area of approximately $390 \mathrm{mi}^{2}$, therefore, the average amount of water derived annually from precipitation is calculated to be about 207,000 acre-feet. Total streamflow entering the valley may add about 167,000 acre-feet. (See section entitled "Surface Water.") There is no surface-water outflow, and if it is assumed that ground-water outflow from the valley is equal to ground-water inflow, then total evapotranspiration is about 1.5 feet per year (374,000 acre-feet).

The estimate derived in the manner outlined above may be too high because ground-water outflow from the valley probably exceeds ground-water inflow. This may occur because of high water tables induced by surface inflow and irrigation. Estimates of transmissivity in the surficial deposits underlying the valley suggest, however, that ground-water outflow is a small fraction of the water lost through evapotranspiration. (See section entitled "Ground Water.") The estimate of evapotranspiration appears reasonable in the light of the

TABLE 1.-Annual precipitation and temperature at three U.S. Weather Service stations in and near Warner Valley for the period 1963-77

\begin{tabular}{lccc} 
Station & [Data from the National Climatic Center, Asheville, N.C.] \\
\hline & $\begin{array}{c}\text { Approximate } \\
\text { altitude } \\
(\mathrm{ft})\end{array}$ & $\begin{array}{c}\text { Average annual } \\
\text { precipitation } \\
\text { (in) }\end{array}$ & $\begin{array}{c}\text { Average annual } \\
\text { temperature } \\
\left({ }^{\circ} \mathrm{C}\right)\end{array}$ \\
\hline Adel & 4,560 & 9.9 & 9.4 \\
Hart Mountain -- & 5,616 & 11.8 & 6.4 \\
Lakeview & 4,740 & 16.5 & 8.0 \\
\hline
\end{tabular}


available water supply, the many lakes and ponds, and the relatively high water table.

The amount of direct evaporation from lakes in the valley is not known. On the basis of a comparison with three lakes in the surrounding region that have depths similar to the larger lakes of Warner Valley, it seems likely that evaporation from lake surfaces is on the order of 3.3 feet per year. The lakes used for this comparison are Abert, 3.5 feet; Summer, 3.5 feet; and Harney, 3.3 feet (Langbein, 1961). Because of the large fluctuations in lake size from year to year, no estimate has been made of the total evaporative loss from lake surfaces in Warner Valley. In the area south of parallel $42^{\circ} 30^{\prime}$, the maximum surface area of lakes is about 30 $\mathrm{mi}^{2}$ and evaporation from the lake surfaces is probably less than 20 percent of the total evapotranspiration. Near the north end of the valley, ponded water covers a large fraction of the area, and evaporation from lake surfaces may be more than half the total evapotranspiration.

\section{GEOLOGIC SETTING}

Warner Valley is in the Basin and Range physiographic province near its northern boundary with the Columbia Plateaus province. The Basin and Range province is characterized by extension in a thin continental crust, evidence for which in the Warner Valley area consists of typical graben structures having normal boundary faults, seismic activity, and volcanism. The crustal extension in the area began at least 17 million years ago and has continued through Pleistocene time and probably Holocene time (Christiansen and McKee, 1978).

Associated with the zone of crustal extension in Oregon is a belt of bimodal volcanism that originated in southeastern Oregon about 13 million years ago, progressed toward the northwest, and culminated in extensive silicic volcanism at Newberry Volcano, near Bend, Oreg. (MacLeod and others, 1975). The progression of silicic volcanism across southeastern Oregon occurred at a rate of about $7 \frac{1}{2}$ inches per year during the period 5 to 10 million years ago and decreased to about $2 \frac{1}{2}$ inches per year during subsequent times. Precise dates are not available for silicic volcanic rocks in Warner Valley, but extrapolation of ages from surrounding areas suggests an age of about 9 million years for these rocks.

The regional structural pattern in the vicinity of Warner Valley is similar to that described by Donath (1962) in the Summer Lake-Abert Rim area, a horst and graben region located about 25 miles west of Warner Valley. In both areas, a rhombic pattern of faults has occurred in a crustal stress field whose principal stress axis was north-south and whose minimum stress axis was east-west. The resulting faults have major strike-slip components. Superimposed on the rhombic pattern of strike-slip faults are normal faults related to the regional crustal extension. The northern boundary of the zone in which these patterns appear is the Brother's fault zone, a complex transform fault zone located about 10 miles north of Warner Valley on the northern margin of the Basin and Range province.

Two sets of high-angle normal faults occur in Warner Valley, striking about N. $35^{\circ} \mathrm{W}$. and N. $20^{\circ} \mathrm{E}$. These faults probably originated during Pleistocene time or even earlier, and continued to be active in Holocene time. Several thousand feet of dip-slip displacement has occurred in northeast-trending faults (Walker and Swanson, 1968; Larson, 1965). No surface movement along fault planes in Warner Valley has been observed in historic times.

The faults blocks that form the valley walls have been tilted and fractured with only minor warping of the strata. Some, such as the massive block of Hart Mlountain, have apparently been raised above previous levels (Larson, 1965). At the south end of Warner Valley and in Coleman Valley, fracturing and tilting have occurred to a high degree, forming a confused pattern of angled blocks. It is likely that the blocks dropped beneath the valley floor form similar patterns.

Warner Valley is near the center of an active earthquake region in southeast Oregon. A map showing epicenters of historic earthquakes since 1841 (Couch and Lowell, 1971) reveals that the northern extension of the Basin and Range province in Oregon contains at least six areas in which significant numbers of earthquakes have occurred.

The earthquakes probably originate in the earth's crust at an average depth between 12 and 15 miles. The crust in this area may have a thickness between 20 and 25 miles. The earthquakes are the result of crustal ex:tension in a stress field whose minimum compressive stress is oriented east-west. The underlying cause appears to be related to the movement of crustal plates.

An earthquake swarm occurred in Warner Valley in May and June 1968, causing moderate damage to many buildings in the Adel area. The largest quake, with an estimated magnitude of 5.1 (Richter scale), had an epicenter located between Crump and Hart Lakes (Couch and Johnson, 1968). No detectable motion occurred along surficial faults in the area during the quakes, and there were no documented changes in thermal springs and wells, although there are conflicting reports of a significant change in Crump geyser.

A comprehensive analysis of 169 seismic events in the swarm has been made by Schaff (1976). He reports that nearly all the epicenters fall within a rectangle about 15 kilometers long (north-south) and 6 kilometers wide, centered about 3 kilometers northwest of 
Adel. Only one shock registered clearly enough at a sufficient number of stations to reliably indicate a focal mechanism. This shock, the largest of the swarm, occurred on a plane having a dip of $80^{\circ} \mathrm{E}$., and a strike of N. $4^{\circ} \mathrm{E}$. The motion on this plane was oblique slip, with about equal components of left-lateral strike-slip and reverse fault motion (Schaff, 1976, p. 26).

The reverse fault motion implies that the valley block moved upward with respect to the mountain block, and that the maximum stress was compressional rather than tensional. This motion is contrary to the motion as determined by Couch and Johnson (1968), who based their conclusions on data from 11 shocks less well-documented than the one used by Schaff. Other earthquake swarms in the region, such as the one in 1973 at Denio, Nev., about 65 miles east of Warner Valley, have demonstrated tensional horizontal stress as would be expected for the Basin and Range province (Richins, 1974).

Apart from the question of the focal mechanism for the Warner Valley earthquakes, the data of Schaff suggest strongly that the swarm was associated with movements along the western boundary fault and that seismic focal points occurred at depths between 2 and 13 kilometers. The inference is clear that a fault extends to the depths determined for the earthquake hypocenters, and it may also be inferred that such a fault could serve as a conduit for the circulation of thermal waters.

Geologic units in the south half of Warner Valley as modified from the map of Walker and Repenning (1965) are shown in figure 3. Several of the mapped units have been combined for the sake of simplicity. Faults shown on this map were located in 1976 by N. E. Voegtly.

The oldest rocks in the area, exposed on the west face of Hart Mountain, are gently dipping, commonly altered tuffs, tuffaceous sediments, andesite flows, and flow breccias of late Oligocene to middle-Miocene age (Walker and Swanson, 1968). The unit is designated Tvp in figure 3 . Thin, discontinuous basalt flows exposed at the mouth of Deep Creek may be about the same age.

Rocks shown as $\mathrm{Tfb}$ are andesitic and basaltic flows and flow breccias of middle to late Miocene age that correlate in part with the Steens Basalt (Steens Mountain Basalt of Fuller, 1931) which was potassium-argon dated 14.5 to $14.7 \mathrm{~m} . \mathrm{y}$. on a flow high in the unit at Steens Mountain (Evernden and others, 1964). They are also correlative with the Steens Mountain Volcanics (Steens Mountain Andesitic Series of Fuller, 1931) and with the andesite flows overlying the Steens Basalt, which may correlate with the Owyhee Basalt (Renick, 1930). The unit Tfb shown in figure 3 includes, at places, the subdivided units Taf and Tbf mapped by Walker and Repenning (1965).

The Steens Basalt is particularly well exposed at Deep Creek Falls, west of Adel, where massive basalt flows and interbedded tuff and scoria crop out in the canyon. The upper part of the unit is highly feldspathic; diktytaxitic and subophitic textures are common. Where the rocks are porphyritic, plagioclase $\left(\mathrm{An}_{6 i 1)-\tau_{10}}\right)$ is the dominant phenocryst. Olivine, commonly altered, occurs in small to moderate amounts. Flows in the lower section contain calcite (aragonite) and zeolites.

Intrusive rhyolitic and dacitic flows and breccias of Miocene to Pliocene age form small plugs and domes at a few places. Within the area shown in figure 3 , these intrusives occur only on Hart Mountain.

Overlying the basaltic and andesitic flows in the upraised blocks are Tertiary tuffaceous rocks (Tts). These are mostly fine-grained tuffaceous sedimentary rocks and tuffs representing flood plain and shallow lake deposits. They grade upward into pumice lapilli tuffs. Elsewhere, these deposits contain middle to late Miocene fossils correlative to faunas in the Mascall Formation (Downs, 1956) and at Beatty Butte (Wallace, 1946). The unit is correlative in part with the Mascall Formation (Merriam, 1901), the Virgin Valley Beds, (Merriam, 1910), and the upper part of the Cedarville Series (Russell, 1928). These rocks form the steep upper part of the valley walls adjacent to Deep Creek and are believed to underlie the alluvial deposits on the valley floor in at least the southern part of the valley.

An erosional surface with hundreds of feet of relief developed on the tuffaceous sediments (Walker and Swanson, 1968). Overlying the erosional surface are Tertiary basalt flows (Tb). These flows cover the surface of nearly all uplifted fault blocks, including Hart Mountain. The basalt is highly feldspathic, contains slightly altered olivine, and exhibits diktytaxitic texture (Walker and Repenning, 1965). The unit is correlative in part with the widespread grey opentextured olivine basalt (Pliocene) of Wells and Peck (1961) in south-central Oregon.

Constructional volcanic features that are younger than the Tertiary basalt flows occur at two places in the area shown in figure 3 : in the canyon of Twelvemile Creek and on the northeast flank of Hart Mountain. These rocks (QTvf) form large complex exogenous domes and related flows and flow breccias of rhyodacitic composition that are highly modified by erosion. These features may have been emplaced as early as the Miocene or as late as the early Pleistocene.

The remainder of the rock units exposed in the study area are sedimentary volcanic deposits and lacustrine and alluvial sediments dating from late Pliocene to Pleistocene and Holocene. Some of the oldest of these 


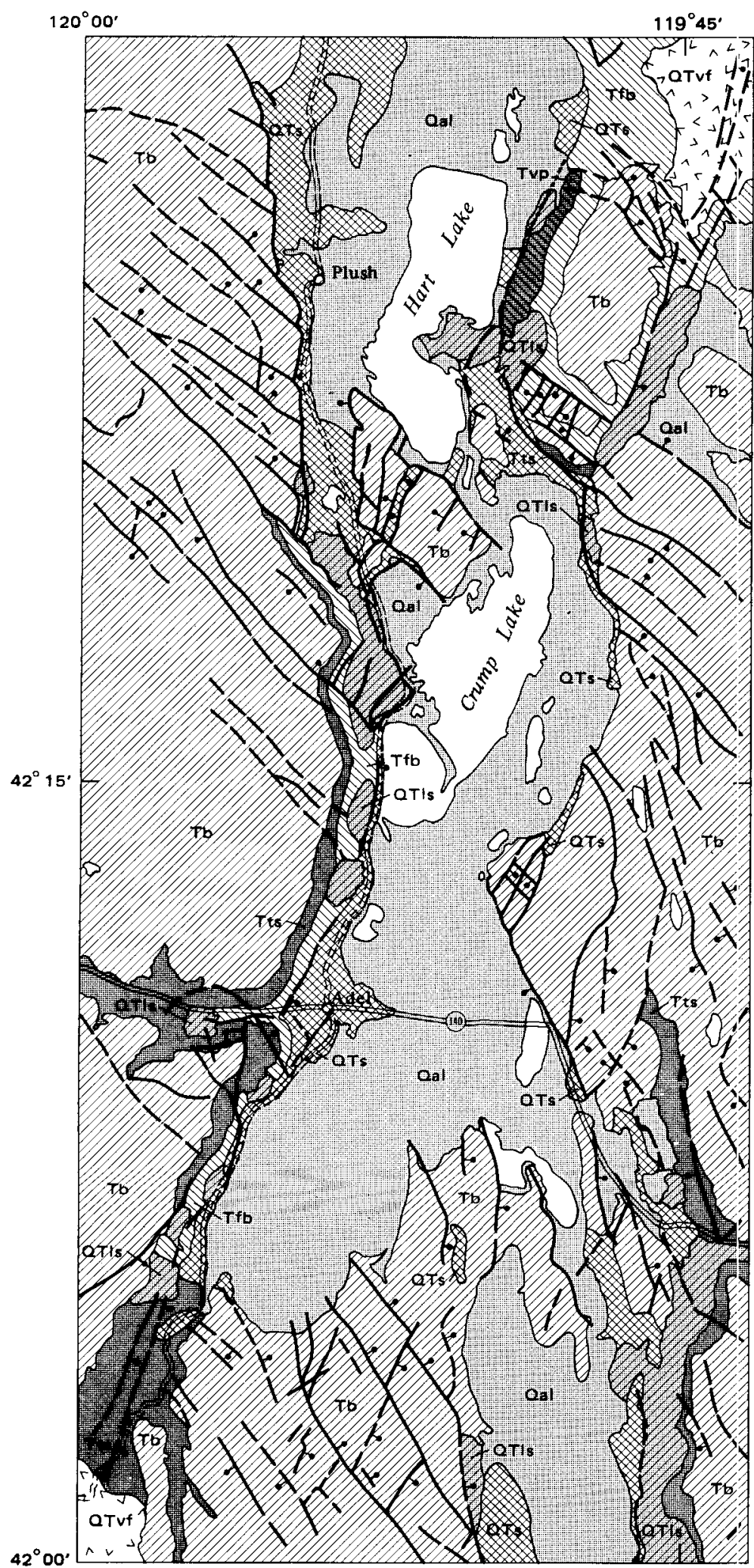

CORRELATION OF MAP UNITS
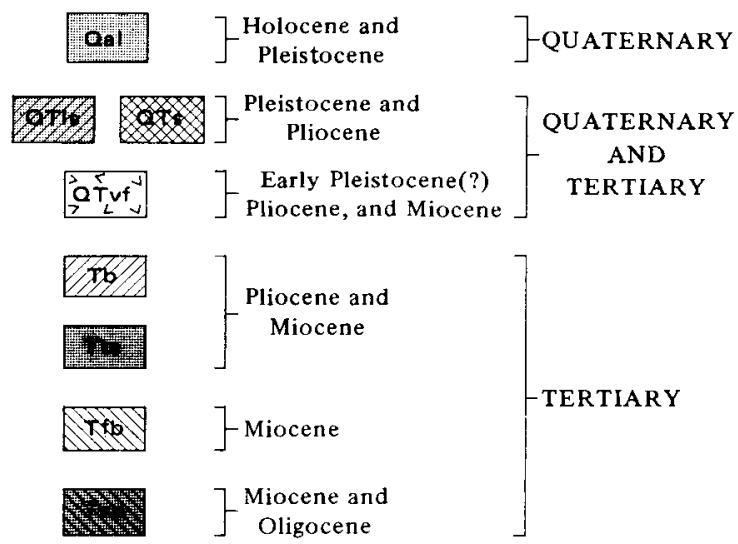

DESCRIPTION OF MAP UNITS

Qal Alluvial deposits. Includes playa deposits, of Walker and Repenning, 1965.

679 Landslide debris. Lacustrine, fluviatile, and aeolian sedimentary rocks, inclu small masses of hot Also includes pediment or fluvial gravel, Qtg, of Walker and Repenning, 1965 .

LTVA Rhyodacitic domes and related flows and flow breccias of rhyodacitic composition.

Basalt flows; feldspathic olivine basalt.

Tuffaceous sedimentary rocks and tuffs

Kro Basalt and andesite flows and flow breccias, variable in texture and mineral composition. variable in texture and mineral composition. Walker and Repenning, 1965.

Tuffaceous sedimentary rocks and tuffs.

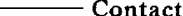

I-... Fault-Dashed where approximately located; dotted where inferred. Bar and ball on down thrown side.

Base from U. S. Geological Survey, 1962

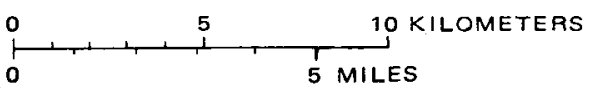

FIGURE 3.-Geologic map of the Warner Valley area (modified from Walker and Repenning, 1965). 
rocks, designated Qts, consist of lacustrine, fluviatile, and eolian sediments, with interstratified tuff, ashy diatomite, and unconsolidated clay, silt, sand, and gravel. This unit is correlative in part with Pliocene and Pleistocene waterlaid volcanic deposits and Pleistocene terrace deposits of Wells and Peck (1961). Pediment or fluvial gravel (included with Qts in fig. 3) that covers the lower slopes of the valley walls at places may represent former pluvial lake levels.

During Pleistocene time, a single large lake occupied the graben. According to Weide (1974), the water reached a maximum depth of about 320 feet prior to 17,000 B.P. The lake had a surface area of about 500 $\mathrm{mi}^{2}$ and drained to the north into the Harney Basin. Beach features are not well defined at the highest levels, but conspicuous shorelines exist on the fault scarps at several lower levels. According to Weide, the shorelines dip toward the south and have warped at an average rate of 2.4 feet per thousand years over the past 17,000 years.

A large delta was constructed at the mouth of Deep Creek during the period of high lake levels. The surface of this delta is now at least 200 feet above the valley floor. As lake levels dropped, the delta was dissected by Deep Creek, leaving steep-sided remnants along a former stream course. Deep Creek now flows south of the delta in order to reach the valley floor.

Two U.S. Geological Survey drill holes in the valley floor, MC1 and MC2 (pl. 1), penetrated lacustrine sediments to depths of 839 and 658 feet, respectively, before reaching basaltic bedrock. An exploratory hole drilled by the San Juan Oil Co. 1 mile east of Adel reportedly encountered basalt at a depth close to 800 feet. The basalt is probably part of a sequence of tuffaceous sedimentary rocks, tuffs, and interbedded basaltic and andesitic flows similar to those exposed in an upraised block about 3 miles east of the study area (rock unit Tsb of Walker and Repenning, 1965). This unit may be correlative in part with the Yonna Formation (Newcomb, 1958) that is prominently exposed in several valleys west of the area, and with numerous similar formations occurring elsewhere in eastern Oregon and Idaho.

Northward from Plush, the valley floor contains swampy areas and playa lakes, surrounded by windblown sand. Similar conditions are found in Coleman Valley, near the Nevada State Line. Evaporite deposits, including potash, borates, and ulexite, occur in the playas in noncommercial quantities.

Talus deposits and landslide debris cover the base of most steep fault scarps (QTls, fig. 3). Below Hart Mountain, for example, a large landslide forms a series of hummocky hills that extend several miles onto the valley floor. The debris consists of unsorted mixtures of basaltic and tuffaceous material ranging in grain size from large boulders to sand and silt.

Geophysical investigations conducted by the U.S. Geological Survey in Warner Valley and Coleman Valley include a truck-borne magnetometer survey, an aeromagnetic survey, gravity measurements, and partial coverage by the audio-magnetotelluric method (AMT) (Gregory and Martinez, 1975; Plouff and Conradi, 1975). Reports on the findings provide estimates of thickness of the valley-fill deposits at several places and show the locations of major boundary faults. The AMT data define a shallow zone of low-resistivity rocks in one part of the valley near Crump geyser. (See section entitled "Distributions of Temperature and Heat Flow.")

The magnetometer and gravity surveys generally coincide in depicting the north-trending faults that bound the east and west sides of the valleys. Both the magnetic and gravitational discontinuities are more pronounced on the west side of the valley than on the east side, suggesting that the western boundary fault zone is better defined than the eastern at most places. Several of the northwest-trending faults that cut the upraised blocks on both sides of the valley are indicated by trends in the data. The cross trends are especially notable in the vicinity of Crump geyser and Fisher Hot Spring, and the intersecting faults mapped in the upraised blocks may extend, into the valley-fill deposits. At other places along the main boundary faults, such as the mouth of Deep Creek canyon, step faulting with a lateral spacing of approximately $3 / 4$ miles is indicated by the magnetometer data.

A major feature of the gravity map is a large region of low gravity centered in the valley about 3 miles south of Adel. A maximum thickness of alluvium of about 2,700 feet can be calculated from the residual anomaly if the average density of the alluvium is assumed to be 2.0 grams per cubic centimeter $\left(\mathrm{g} \mathrm{cm}^{-3}\right)$ and the density of underlying Tertiary rocks is $2.5 \mathrm{~g}$ $\mathrm{cm}^{-3}$. However, gravity data from elsewhere in the valley indicate that the rocks most likely to underlie the valley floor in the southern half of Warner. Valley are tuffaceous sedimentary rocks and tuffs which may have densities not much greater than those of the deeper valley-fill deposits. Thus, the depth of alluvium may be much less than the 2,700 feet calculated on the basis of a maximum density contrast between alluvium and an underlying basaltic bedrock. Depths of alluvium estimated from some of the more reliable truck-borne magnetometer data range from 200 feet in Coleman Valley and the northwest edge of Greaser Reservoir to 500 feet at a location 1 mile south of Fisher Hot Spring. Near the southern boundary of Warner Valley in Township 40 S., Range 24 E., the 
estimated depth to bedrock is 400 feet.

The aeromagnetic map shows a major magnetic low that coincides with the large gravity low south of Adel and which is consistent with the presence of a thick slab of relatively nonmagnetic sediments in this part of the Valley. A large magnetic high is centered on the boundary between sections 9 and 16 , Township $40 \mathrm{~S}$., Range 24 E. at the extreme south end of Warner Valley. The cause of the magnetic anomaly at this location is not known.

The gravity and magnetic surveys are helpful in outlining the large-scale structural features in the area, but they are not sufficiently detailed to delineate small structural features and they do not provide clues to the depth and extent of deep reservoirs that could supply the geothermal waters.

\section{SURFACE WATER}

Warner Valley is a closed basin with no surface drainage outlet. Two perennial streams, Twentymile Creek and Deep Creek, enter the valley near its southern end, and a third, Honey Creek, enters near Plush. All three streams have their sources in the Warner Range. During the winter and early spring, many ephemeral streams flow into the valley from canyons in the valley walls.

Surface flow in the southern part of the valley is generally toward the north with a gradient of approximately $1.5 \times 10^{-4}(0.8$ feet per mile $)$. To the north of Hart Lake, the gradient is virtually zero and the area is an evaporative sump.

Streamflow entering the valley in Twentymile, Honey, and Deep Creeks is gaged, and records are available for periods of years ranging from 44 to 53. Data for the period prior to 1976 are given in table 2 .

The amount of water entering the valley in ungaged streams has been measured during only one period of

TABLE 2.-Average annual streamflow entering Warner Valley in Deep Creek, Honey Creek, and Twentymile Creek for the period of record prior to 1976

\begin{tabular}{|c|c|c|c|c|}
\hline \multirow{2}{*}{ Station } & \multirow{2}{*}{$\begin{array}{l}\text { Latitude, } \\
\text { longitude }\end{array}$} & \multirow{2}{*}{$\begin{array}{l}\text { Years of record } \\
\text { prior to } 1976\end{array}$} & \multicolumn{2}{|c|}{ Average discharge } \\
\hline & & & $\left(\mathrm{ft}^{1} \mathrm{~s}^{-1}\right)$ & (acre-ft $\mathrm{yr}^{-1}$ ) \\
\hline $\begin{array}{l}\text { Deep Creek, } \\
5 \text { miles west } \\
\text { of Adel. }\end{array}$ & $\begin{array}{r}42^{\circ} 11^{\prime} 21^{\prime \prime} \\
120^{\circ} 00^{\prime} 02^{\prime \prime}\end{array}$ & 47 & 131 & 94,910 \\
\hline \multirow{2}{*}{$\begin{array}{l}\text { Honey Creek, } \\
1 \text { mile north- } \\
\text { west of Plush. }\end{array}$} & $42^{\circ} 25^{\prime} 30^{\prime \prime}$ & 49 & 30.4 & 22,020 \\
\hline & $119^{\circ} 55^{\prime} 20^{\prime \prime}$ & & & \\
\hline $\begin{array}{l}\text { Twentymile } \\
\text { Creek, 1.5 } \\
\text { miles down- } \\
\text { stream from } \\
\text { Twelvemile } \\
\text { Creek. }\end{array}$ & $\begin{array}{r}42^{\circ} 04^{\prime} 20^{\prime \prime} \\
119^{\circ} 57^{\prime} 42^{\prime \prime}\end{array}$ & 40 & 53.2 & 38,540 \\
\hline
\end{tabular}

time, so far as is known to the authors. For the years 1909-15, average ungaged flow is estimated to have been about 7.3 percent of the gaged streamflow (Whistler and Lewis, 1916). The annual percentages ranged from 2.4 percent to 14.1 percent, with the lower percentages occurring in years of lower flow. If the same conditions hold for the period of record shown in table 2 , the average ungaged streamflow may be about 11,350 acre-foot per year (acre-ft $\mathrm{yr}^{-1}$ ). Most of this flow occurs during the 4-month period January through April.

\section{GROUND WATER}

The characteristics of ground water in the study area are known from data on 66 wells and heat-flow holes and 57 springs. The data from these wells and springs are given in tables 3 and 4 and locations are shown in plate 1.

Most of the wells in Warner Valley penetrate alluvial or lacustrine deposits to depths less than 300 feet. Many of the wells situated near the valley walls also penetrate small thicknesses of volcanic breccia, cinders, and one or more thin basalt flows. Only one well is known to penetrate a fairly thick sequence of basaltic rocks in a raised fault block.

Water levels at most places are within 30 feet of the land surface except in the former delta of Deep Creek, near Adel, where water levels are as much as 70 to 90 feet below land surface. Wells having depths greater than about $250^{\circ}$ feet generally have hydraulic heads above land surface as the result of pressures transmitted from aquifers at higher levels in the upraised fault blocks. No measurements of static heads in these artesian wells are available, but heads measured in three heat-flow holes, MC1, MC2, and OK1, at depths ranging from 350 to 500 feet, were 1 to 3 feet albove land surface. Artesian heads are believed to be generally low throughout the valley.

Springs are widely scattered in the valley and the adjacent highlands. They range in type from simple gravity springs fed by local precipitation to thermalartesian springs fed, in part, by deep geothermal reservoirs. Nearly half the springs inventoried for the study are cold gravity springs that issue on the surfaces of fault blocks that flank the valley. The remainder, including most thermal springs, occur on or near the valley floor, most of them at the base of talus slopes or fa.ult scarps. Many have no well-defined openings, but ase merely seeps that, in some cases, extend for hundreds of feet along the bases of the fault scarps. A few springs occur in the alluvium at some distance from the valley walls where there is no visible reason for their occurrence.

Thermal springs in the study area cannot be distinguished from nonthermal springs on the basis of 
Sequence No.--Identifying number or letter used in tables and illustrations.

Location-Based on township, range, and section. See figure 2 for key.

Completion-OH, open hole; $\mathrm{P}$, perforated (depth interval in feet).

Altitude-Land surface at well, in feet above National Geodetic Vertical Datum of 1929, estimated from U.S. Geological Survey topographic quadrangle maps.

Depth to water-Feet below land surface; F, flowing at land surface.

Yield-Gallons per minute ( $\mathrm{gal} \mathrm{min}^{-1}$ ).

Temperature-Maximum water temperature in degrees Celsius after pumping; in unused wells where temperature profile was obtained, temperature is maximum measured at depth given (feet).

Specific conductance-Micromho per centimeter at $25^{\circ} \mathrm{C}$.

Use-D, domestic; I, irrigation; S, stock; T, USGS test hole; U, unused.

Driller's log-O, owner; D, driller's records; SE, Oregon State Engineer's records; T, Trauger, 1950; US, U.S. Geological Survey.

Other data-C, chemical analysis, table $6 ; \mathrm{I}$, isotope analysis, table 8 ; T, temperature profile, USGS, figures 13 and 14 .

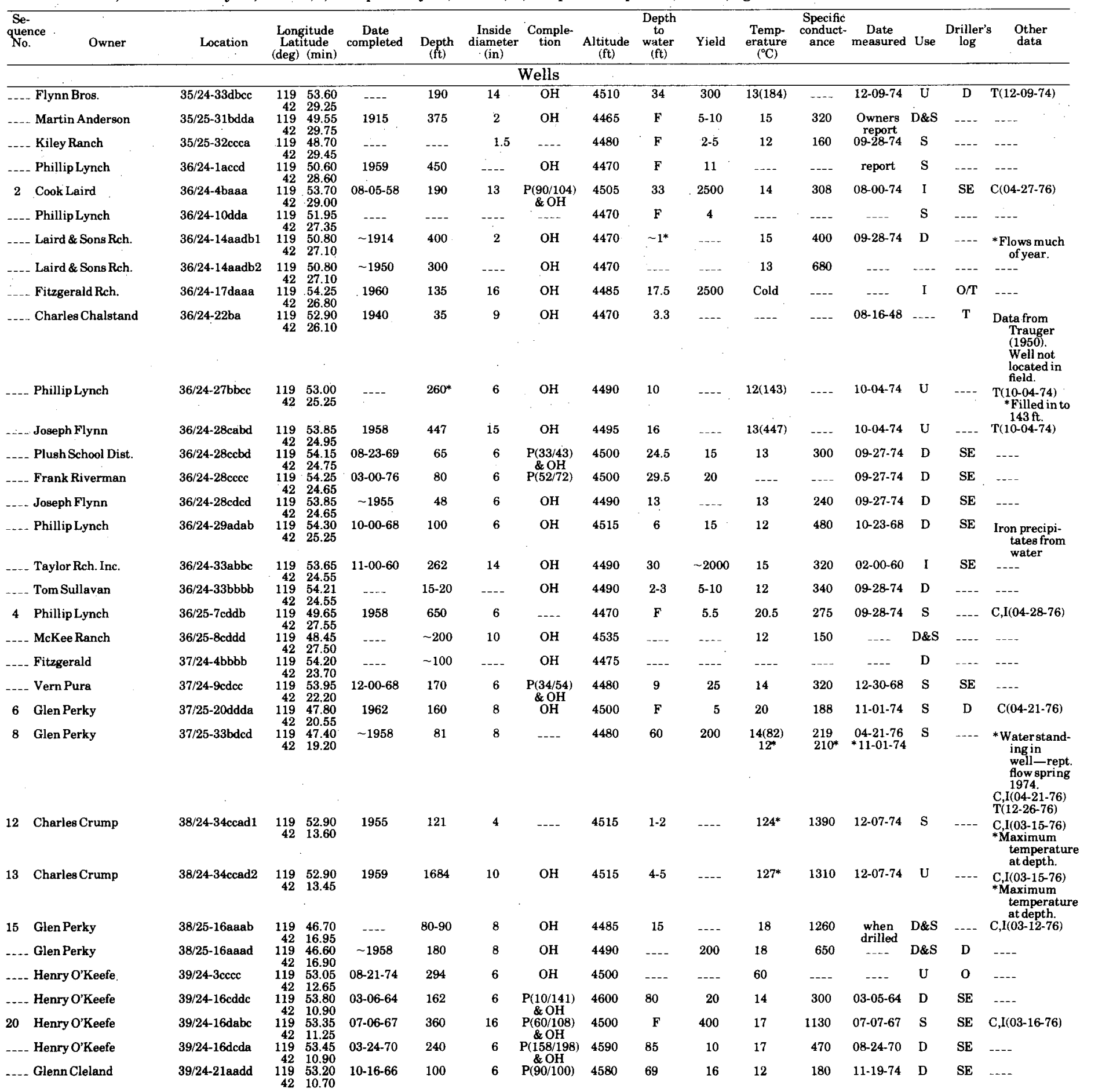


TABLE 3.-Datafrom wells and heat-flow holes-Continued

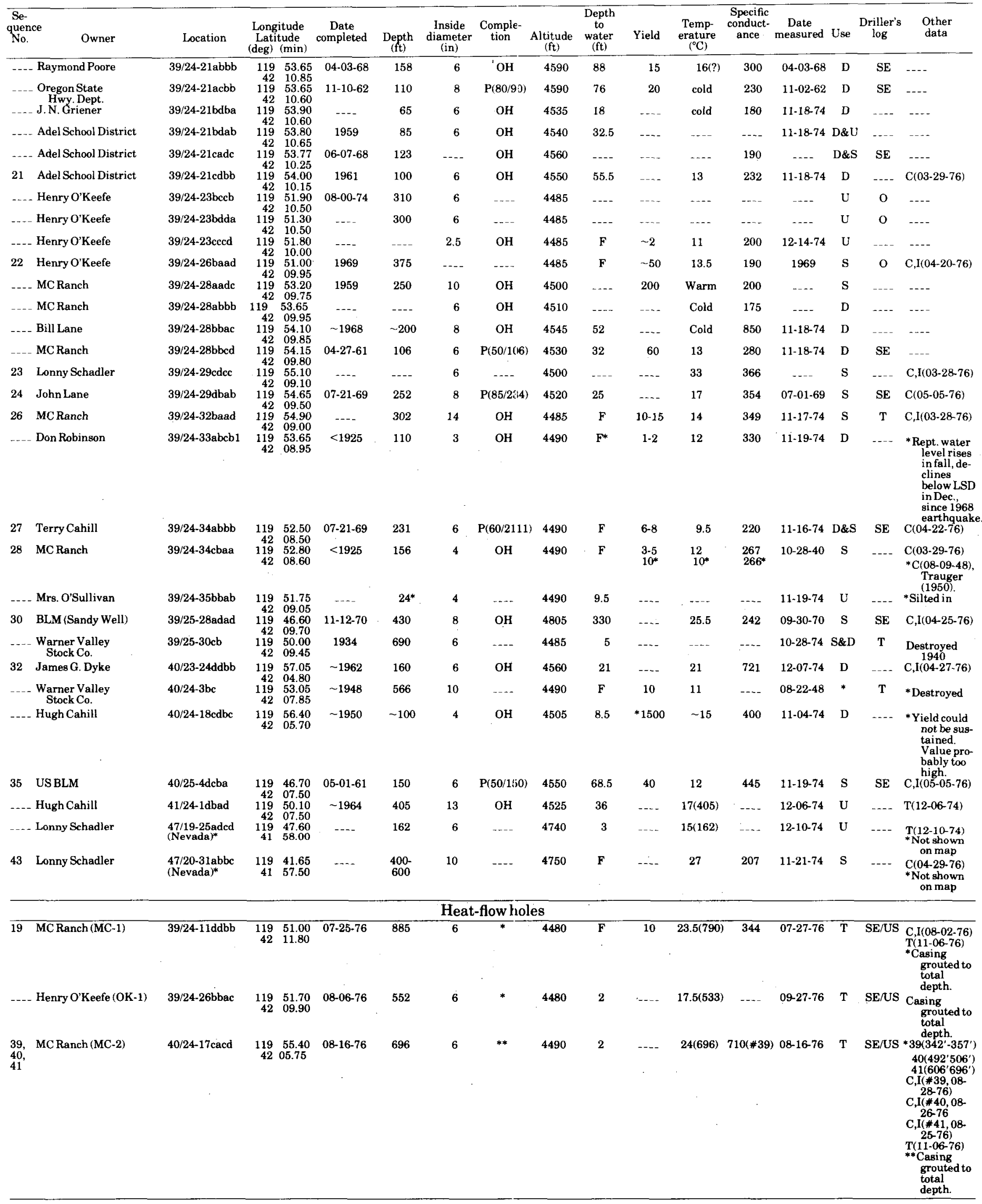


TABLE 4,-Datafrom selected springs

Sequence No.-Identifying number used in tables and illustrations.

Location-Based on township, range, and section. See figure 2 for key.

Altitude_Land surface at spring, in feet above National Geodetic Vertical Datum of 1929, estimated from Geological Survey topographic quadrangle maps.

Yield-Gallons per minute (gal $\left.\mathrm{min}^{-1}\right)$.

Specific Conductance-Micromho per centimeter at $25^{\circ} \mathrm{C}$.

Use-D, domestic; S, stock; U, unused.

Other data-C, chemical analysis in table 6; I, isotope analysis in table 8.

\begin{tabular}{|c|c|c|c|c|c|c|c|c|c|c|c|c|c|}
\hline $\begin{array}{l}\text { Sequence } \\
\text { No. }\end{array}$ & Owner & Spring name & Location & $\begin{array}{l}\text { Longitude } \\
\text { Latitude }\end{array}$ & $\begin{array}{l}\text { Altitude } \\
(\mathrm{ft})\end{array}$ & $\begin{array}{l}\text { eProbable water-bearing } \\
\text { materials }\end{array}$ & Occurence & Yield & $\begin{array}{l}\text { Temp- } \\
\text { erature } \\
\left({ }^{\circ} \mathrm{C}\right)\end{array}$ & $\begin{array}{l}\text { Specific } \\
\text { conduct- } \\
\text { ance }\end{array}$ & Date & Use & Other data \\
\hline--- & Kiley Ranch & Anderson Spr. & $35 / 25-32$ dedd & $\begin{array}{r}11948.10 \\
\mathbf{4 2} 29.25\end{array}$ & 4525 & Valley-fill deposits & gravity & $5-10$ & 16 & 100 & $09-28-74$ & $\mathrm{~S}$ & --- \\
\hline 45 & $\begin{array}{l}\text { USFish \& } \\
\text { Wildlife }\end{array}$ & Valet Spr. & $35 / 26-28 b c c c$ & $\begin{array}{r}11940.65 \\
4230.55\end{array}$ & 5880 & $\begin{array}{l}\text { Contact-tuffaceous sedi- } \\
\text { ments, volcanic dome }\end{array}$ & -.-- & --- & 14 & 448 & $07-15-80$ & $\mathrm{D \& S}$ & $\mathrm{C}(07-15-80)$ \\
\hline 1 & $\begin{array}{l}\text { USFish \& } \\
\text { Wildlife }\end{array}$ & Antelope Hot Spr & $35 / 26-32 \mathrm{baba}$ & $\begin{array}{r}11941.75 \\
4230.00\end{array}$ & 6000 & Volcanic dome & $\begin{array}{l}\text { thermal- } \\
\text { artesian }\end{array}$ & $10-12$ & 40 & 876 & $-\ldots$ & D\&S & $\begin{array}{l}C(08-10-48) \\
\mathrm{I}(03-00-77)\end{array}$ \\
\hline- & McKee Ranch & ..-- & $36 / 25-8 c d(a \& d)$ & $\begin{array}{r}11948.35 \\
4227.60\end{array}$ & 4520 & Lake terrace sediments & $-\ldots$ & 0 & 8 & 160 & $09328-74$ & $\mathrm{~s}$ & 2 large seeps. \\
\hline 5 & $\begin{array}{l}\text { USFish \& } \\
\text { Wildlife }\end{array}$ & $-\cdots$ & $36 / 25-9 \mathrm{cdcd}$ & $\begin{array}{r}11947.45 \\
4227.50\end{array}$ & $\begin{array}{l}4980- \\
5000\end{array}$ & Tertiary basaltic flows & gravity & $10-15$ & 4 & 77 & $09-28-74$ & $\mathrm{U}$ & $\begin{array}{l}\mathrm{C}, 1(05-03-76) \text { Linear seeps } \\
\text { in deep canyon. }\end{array}$ \\
\hline$\cdots$ & $\begin{array}{l}\text { US Fish \& } \\
\text { Wildlife }\end{array}$ & $\cdots$ & 36/25-30daaa & $\begin{array}{r}11948.85 \\
4225.30\end{array}$ & 4825 & Tertiary basaltic flows & gravity & --- & 6 & 230 & --- & $\mathrm{S}$ & --- \\
\hline---- & $\begin{array}{l}\text { US Fish \& } \\
\text { Wildlife }\end{array}$ & $-\cdots$ & $36 / 25-30$ daba & $\begin{array}{r}11949.10 \\
42.5 .20\end{array}$ & 4660 & $\begin{array}{l}\text { Contact-tuffaceous sedi- } \\
\text { ments, basaltic flows }\end{array}$ & gravity & $10^{*}$ & 11 & 245 & $09-20-48^{*}$ & $S$ & *Trauger $(1950)$ \\
\hline -..- & Ancore & $\ldots$ & $37 / 24-23$ bacd & $\begin{array}{r}11951.55 \\
4221.15\end{array}$ & 4480 & Tertiary baalts & $\begin{array}{l}\text { Thermal- } \\
\text { artesian }\end{array}$ & 10 & 21 & 320 & $09-29-74$ & $\mathrm{U}$ & $\begin{array}{l}\text { Artesian head } \sim 1 / 2 \mathrm{ft} \text { above } \\
\text { LSD in casing. }\end{array}$ \\
\hline$\ldots$ & US BLM & Lynch Spr. & $37 / 24-30 \mathrm{cdcb}$ & $\begin{array}{r}11956.30 \\
4219.65\end{array}$ & 5740 & Tertiary basalts & gravity & 3 & 10 & 120 & $11-03-74$ & $\mathbf{S}$ & --- \\
\hline--- & Mrs.Calder- & --- & $37 / 25-28 \mathrm{bcbd}$ & $\begin{array}{r}11947.40 \\
4220.20\end{array}$ & 4490 & $\begin{array}{l}\text { Volcanic and lacustrine } \\
\text { sediments }\end{array}$ & thermal- & $3 \cdot 5$ & 20 & 200 & $11-01-74$ & $\mathrm{~s}$ & ---- \\
\hline$\cdots$ & Glen Perky & --- & 37/25-28bdca & $\begin{array}{r}11947.35 \\
4220.10\end{array}$ & 4500 & $\begin{array}{l}\text { Volcanic and lacustrine } \\
\text { sediments }\end{array}$ & $\begin{array}{l}\text { Thermal- } \\
\text { artesian }\end{array}$ & 1.3 & 24 & 200 & $11-01-74$ & $\mathrm{~S}$ &.-- \\
\hline 7 & Dixon & --- & $37 / 25-30 \mathrm{dccb}$ & $\begin{array}{r}11949.50 \\
4219.65\end{array}$ & 4480 & $\begin{array}{l}\text { Contact-Tertiary basalts, } \\
\text { valley-fill deposits }\end{array}$ & ${ }_{1-5}$ & 27 & 370 & $10-04-74$ & $\mathrm{~s}$ & $\mathrm{C}(04-20-$ & -76) \\
\hline-- & Dixon & $-\cdots$ & 37/25-30decc & $\begin{array}{r}11949.50 \\
4219.55\end{array}$ & 4490 & $\begin{array}{l}\text { Contact-Tertiary basalts, } \\
\text { valley-fill deposits }\end{array}$ & gravity & 1 & 11 & 430 & $04-20-76$ & 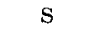 & $-\cdots$ \\
\hline--- & $\begin{array}{l}\text { USFish \& } \\
\text { Wildlife }\end{array}$ & --- & $37 / 35-33 \mathrm{ba}$ & $\begin{array}{r}11947.35 \\
4219.50\end{array}$ & 4500 & $\begin{array}{l}\text { Volcanic and lacustrine } \\
\text { sediments }\end{array}$ & gravity & 20 & --- & --- & $09-24-48$ & ---- & $\begin{array}{l}\text { Trauger (1950). Not } \\
\text { visited. }\end{array}$ \\
\hline---- & John Lane & $-\cdots$ & 38/24-3bdad & $\begin{array}{r}11952.50 \\
4218.40\end{array}$ & 4485 & $\begin{array}{l}\text { Landslide debris and Ter- } \\
\text { tiary basalt flows }\end{array}$ & $\begin{array}{l}\text { thermal- } \\
\text { gravity }\end{array}$ & $2-4$ & 20 & 210 & $09-30-74$ & $\mathrm{~s}$ & --- \\
\hline-- & John Lane & ---- & $38 / 24-3 \mathrm{dcdc}$ & $\begin{array}{r}11952.35 \\
4217.85\end{array}$ & 4485 & $\begin{array}{l}\text { Landslide debris and Ter- } \\
\text { tiary basalt flows }\end{array}$ & $\begin{array}{l}\text { thermal- } \\
\text { artesian }\end{array}$ & $<1$ & 24 & 200 & $09-30-74$ & $\mathrm{~S}$ & $-\cdots$ \\
\hline 9 & USBLM & Coxes Spr. & 38/24-6dbad & $\begin{array}{r}11955.80 \\
4218.15\end{array}$ & 6090 & Tertiary basalts & gravity & $5-10$ & 6 & 110 & $11-03-74$ & $\mathrm{~s}$ & $\mathrm{C}, \mathrm{I}(04-18-76)$ \\
\hline--- & John Lane & --- & $38 / 24-10 a c d b$ & $\begin{array}{r}11952.35 \\
4217.50\end{array}$ & 4490 & $\begin{array}{l}\text { Valley-fill deposits (Ter- } \\
\text { tiary basalts?) }\end{array}$ & $\begin{array}{l}\text { thermal- } \\
\text { gravity }\end{array}$ & $5-10$ & 25 & 220 & $09-30-74$ & $\mathrm{~s}$ & Hotom \\
\hline 10 & John Lane & ---- & 38/24-10dadd & $\begin{array}{r}11952.00 \\
4217.25\end{array}$ & 4500 & Tertiary basalts & $\begin{array}{l}\text { thermal- } \\
\text { gravity }\end{array}$ & $10-15$ & 29 & 162 & $09-30-74$ & $\mathbf{S}$ & $\begin{array}{l}\text { Almost continuous seeps } \\
\text { and flows for } 1 / 4 \text { mile. } \\
\text { C,I (04-18-76). }\end{array}$ \\
\hline--- & John Lane & ---- & $38 / 24-14 b(b-c)$ & $\begin{array}{r}11951.75 \\
4216.70\end{array}$ & 4480 & $\begin{array}{l}\text { Valley-fill deposits (Ter- } \\
\text { tiary basal ts?) }\end{array}$ & $\begin{array}{l}\text { gravity } \\
\text { (inter- } \\
\text { mittent) }\end{array}$ & 0 & $-\cdots$ & $-\cdots$ & $09-30-74$ & $\mathrm{~S}$ & $\begin{array}{l}\text { Water level - } 1 \mathrm{ft} \text { below } \\
\text { LSD 09-30-74. }\end{array}$ \\
\hline---- & --- & $-\cdots$ & $38 / 24-22 b d(a-d)$ & $\begin{array}{r}11952.55 \\
4215.80\end{array}$ & 4475 & Tertiary basalts & gravity & $4-5$ & 24 & 275 & $12-14-79$ & $\mathrm{U}$ & Line of seeps at lake level. \\
\hline 11 & Charles Crump & --- & $38 / 24-27 \mathrm{cddb}$ & $\begin{array}{r}11952.60 \\
4214.45\end{array}$ & $4500(?)$ & Tertiary basalts & $\begin{array}{l}\text { thermal- } \\
\text { artesian }\end{array}$ & 5 & 40 & 935 & $09-09-48$ & $\mathrm{~S}$ & Trauger (1950) C(09-16- \\
\hline 14 & MC Ranch & ---- & 38/24-34cdbd & $\begin{array}{r}11952.70 \\
4213.90\end{array}$ & 4490 & $\begin{array}{l}\text { Lacustrine sediments } \\
\text { (Tertiary basalts) }\end{array}$ & $\begin{array}{l}\text { thermal- } \\
\text { artesian }\end{array}$ & $5-10$ & $70-80$ & 1490 & $12-07-74$ & $\mathrm{~S}$ & $\begin{array}{l}\text { Numerous widespread } \\
\text { seeps. C,I(08-03-72) }\end{array}$ \\
\hline 14 & Glen Perky & $\begin{array}{l}\text { Fisher Hot } \\
\text { Spr. }\end{array}$ & $38 / 25-10 \mathrm{bbbb}$ & $\begin{array}{r}11946.55 \\
4217.85\end{array}$ & 4510 & Tertiary basalts & thermal & $15-20$ & 68 & 513 & $09-22-74$ & $\mathrm{D}$ & $\begin{array}{l}\text { SeeTrauger (1950), Bowen } \\
\text { and Peterson (1970), } \\
\text { Mariner and others } \\
(1974,1975) . C(08-02- \\
72)(103-00-77)\end{array}$ \\
\hline 16 & US BLM & --- & 38/25-21abdc & $\begin{array}{r}11947.00 \\
4215.90\end{array}$ & 4490 & Valley-fill deposits & $\begin{array}{l}\text { thermal- } \\
\text { artesian }\end{array}$ & $1-3$ & 38 & 440 & $11-01-74$ & $\mathrm{~S}$ & $\begin{array}{l}\text { Developed, } 2.5 \mathrm{ft} \text { casing in } \\
\text { large seep area. C,I (03- } \\
17-76)\end{array}$ \\
\hline 17 & Terry Cahill & --- & $38 / 25-30$ dddd & $\begin{array}{r}11948.95 \\
4214.35\end{array}$ & 4478 & Valley-fill deposits & artesian & $1-10$ & 14 & 366 & $05-05-76$ & $\mathrm{~S}$ & $\mathrm{C}(05-05-76)$ \\
\hline 46 & Henry O'Keefe & $-\ldots$ & 39/24-3dcbc & $\begin{array}{r}11952.45 \\
4212.75\end{array}$ & 4485 & Valley-fill deposits & $\begin{array}{l}\text { thermal- } \\
\text { artesian }\end{array}$ & $2-3$ & 58 & 1400 & $07-19-80$ & $\mathrm{U}$ & $\begin{array}{l}\text { Large area of sinter depos- } \\
\text { its. At least six other } \\
\text { seeps and spring } 35 \text { to } \\
49^{\circ} \mathrm{C} \text {. C }(07-19-80)\end{array}$ \\
\hline 18 & Charles Crump & Crump Spr. & $39 / 24-4 \mathrm{badc}$ & $\begin{array}{r}11953.80 \\
4213.45\end{array}$ & 5960 & $\begin{array}{l}\text { Probable contact, Tertiary } \\
\text { tuffs over basalt flows }\end{array}$ & gravity & 10 & 6 & 95 & $03-16-76$ & $\mathbf{S}$ & $\mathrm{C}, \mathrm{I}(03-16-76)$ \\
\hline$-\cdots$ & US BLM & -+- & $39 / 24-18$ cddd & $\begin{array}{r}11956.15 \\
4210.90\end{array}$ & 5400 & Tuffaceous sediments & gravity & 0.2 & 13 & 200 & $11-04-74$ & $S$ & --- \\
\hline 25 & MC Ranch & $-\cdots$ & 39/24-31babd & $\begin{array}{r}11956.20 \\
4209.00\end{array}$ & 5150 & $\begin{array}{l}\text { Contact, tuffaceous sedi- } \\
\text { ments, older basalt flows }\end{array}$ & gravity & 10 & 13.5 & 212 & $11-20-74$ & $\mathrm{D}$ & $\mathrm{C}(03-29-76)$ \\
\hline
\end{tabular}

physiographic setting or type of occurrence. Both thermal and nonthermal springs may be gravity fed or have artesian flow. Both occur as seeps on the valley floor and as well-defined artesian flows issuing high on fault blocks. A noteworthy example of the latter is Antelope Hot Spring, which issues from volcanic rocks on Hart Mountain at an altitude of about 6,000 feet.

Thermal waters have been defined, in this area, as 
TABLE 4.-Datafrom selected springs-Continued

\begin{tabular}{|c|c|c|c|c|c|c|c|c|c|c|c|c|c|}
\hline $\begin{array}{l}\text { Sequence } \\
\text { No. }\end{array}$ & Owner & Spring name & Location & $\begin{array}{l}\text { Longitude } \\
\text { Latitude }\end{array}$ & $\underset{(\mathrm{ft})}{\text { Altitude }}$ & $\begin{array}{l}\text { eProbable water-be aring } \\
\text { materials }\end{array}$ & Occurence & Yield & $\begin{array}{l}\text { Temp- } \\
\text { erature } \\
\left({ }^{\circ} \mathrm{C}\right)\end{array}$ & $\begin{array}{l}\text { Specific } \\
\text { conduct- } \\
\text { ance }\end{array}$ & Date & Use & Other data \\
\hline+- & $\begin{array}{c}\text { Robinson } \\
\text { Ranch }\end{array}$ & $\cdots$ & $40 / 22-15$ bacd & $\begin{array}{r}12006.95 \\
4206.20\end{array}$ & 5590 & Rhyodacitic tuff & gravity & $10-15$ & 11 & 240 & $12-11-74$ & $\mathrm{~S}$ & One of numerous springs \\
\hline-+- & $\begin{array}{c}\text { Robinson } \\
\text { Ranch }\end{array}$ & --- & $40 / 22-20 \mathrm{dccc}^{*}$ & $\begin{array}{r}42009.10 \\
4204.70\end{array}$ & 5620 & Rhyodacitic tuff & gravity & $15-20$ & 7 & 70 & $12-11-74$ & $\mathbf{S}$ & $\begin{array}{l}\text { One outlet at base of mas- } \\
\text { sive outerop at change in } \\
\text { slope.*Not on location } \\
\text { map. }\end{array}$ \\
\hline 31 & $\begin{array}{c}\text { Robinson } \\
\text { Ranch }\end{array}$ & $\cdots$ & $40 / 22-22 \mathrm{babc}$ & $\begin{array}{r}12007.05 \\
4205.45\end{array}$ & 5550 & Rhyodacite flows & thermal & --- & 23 & 151 & $+\cdots$ & $\mathrm{S}$ & $\begin{array}{l}\mathrm{C}, \mathrm{I}(04-28-76) \text { Line of seeps } \\
\text { at base of domal mass. }\end{array}$ \\
\hline--- & $\begin{array}{l}\text { Robinson } \\
\text { Ranch }\end{array}$ & --- & $40 / 22-28$ baca* & $\begin{array}{r}12008.10 \\
4204.50\end{array}$ & 5590 & Rhyodacitic tuff & gravity & $1-2$ & 6 & 80 & $12-11-74$ & $\mathrm{D} \& \mathrm{U}$ & $\begin{array}{l}\text { Shallow, dug out, near } \\
\text { stream. Not on location } \\
\text { map. }\end{array}$ \\
\hline$\cdots-$ & $\begin{array}{l}\text { Robinson } \\
\text { Ranch }\end{array}$ & --- & $40 / 22-29 a c d d^{*}$ & $\begin{array}{r}12008.85 \\
4204.28\end{array}$ & 5660 & Rhyodacitic tuff & gravity & $20-25$ & 12 & 140 & $12-11-74$ & $\mathrm{~S} \& \mathrm{D}$ & $\begin{array}{l}\text { Shallow, dug out and } \\
\text { walled up.* Not on loca- } \\
\text { tion map. }\end{array}$ \\
\hline$-\cdots$ & Henry O'Keefe & e ---- & $40 / 23-36 \mathrm{bca}$ & $\begin{array}{r}11957.65 \\
4203.50\end{array}$ & 4595 & Tuffaceous sediments & gravity & $15-30$ & 34 & 430 & $12-07-74$ & $-\cdots$ & $-\ldots$ \\
\hline 33 & MC Ranch & Foskett Spr. & 40/24-25caaa & $\begin{array}{r}11950.30 \\
4204.20\end{array}$ & 4480 & Tertiary basalts & $\begin{array}{l}\text { thermal- } \\
\text { artesian }\end{array}$ & 15 & 21 & 270 & $11-17-74$ & --- & $\mathrm{C}, \mathrm{I}(04-05-76)$ \\
\hline 34 & Hugh Cahill & Hallinan Spr. (? & $* 40 / 24-29 \mathrm{bcbb}$ & $\begin{array}{r}11955.55 \\
4204.40\end{array}$ & 4530 & Tertiary basalts & thermal & $3-5$ & 66 & 945 & $11-04-74$ & $\mathbf{S}$ & $\begin{array}{l}{ }^{*} \text { Trauger }(1950) . \mathrm{C}, \mathrm{I}(04- \\
05-76)\end{array}$ \\
\hline--- & Hugh Cahill & Hallinan Spr. (? & 40/24-30aaac & $\begin{array}{r}11955.70 \\
4204.55\end{array}$ & 4530 & Tertiary basalts & thermal & $3-5$ & 45 & 670 & $11-04-74$ & $\mathrm{~S}$ & ${ }^{*}$ Trauger $(1950)$ \\
\hline--- & --- & --- & 40/24-36acba & $\begin{array}{r}11950.15 \\
4203.55\end{array}$ & 4480 & $\begin{array}{l}\text { Playa deposits (Tertiary } \\
\text { basalts?) }\end{array}$ & artesian & 3-5 & 16 & 150 & $11-17-74$ & $\mathbf{S}$ & $\ldots$ \\
\hline--- & USBLM & --- & $40 / 25-19 \mathrm{cbac}$ & $\begin{array}{r}11949.45 \\
4205.00\end{array}$ & 4475 & Playa deposits & artesian & $<1$ & 8 & 650 & $11-17-74$ & $\mathrm{~S}$ & $\cdots$ \\
\hline 36 & USBLM & Chukar Spr. & $40 / 25-23 \mathrm{bbbd}$ & $\begin{array}{r}11944.85 \\
4205.45\end{array}$ & 4820 & Tertiary basalt & gravity & 5 & 7 & 130 & $04-18-76$ & $\mathrm{~S}$ & $\mathrm{C}(04-18-76)$ \\
\hline--- & US BLM & $-\cdots$ & $40 / 25-23 c-d$ & $\begin{array}{r}11944.35 \\
4204.80\end{array}$ & $\begin{array}{l}5600 \\
(\mathrm{Max})\end{array}$ & $\begin{array}{l}\text { Tuffaceous sediments and } \\
\text { basalt (Tertiary }\end{array}$ & gravity & $2-5$ & 7 & 210 & $11-21-74$ & $\mathrm{~S}$ & $\begin{array}{l}\text { Springs come from many } \\
\text { sources along canyon } \\
\text { walls. }\end{array}$ \\
\hline$-\cdots$ & USBLM & Burro Spr. & 40/25-34bacd & $\begin{array}{r}11945.75 \\
4203.60\end{array}$ & 4740 & Tuffaceous sediments & gravity & 2 & 11 & 420 & $11-21-74$ & $\mathbf{S}$ & $\begin{array}{l}\text { Much calcium deposits on } \\
\text { nearby rocks. }\end{array}$ \\
\hline 37 & USBLM & RosebriarSpr. & 40/25-36dcac & $\begin{array}{r}11943.05 \\
4203.00\end{array}$ & 6330 & Tuffaceous sediments & gravity & $<1$ & 8.5 & 130 & $11-23-74$ & $\mathbf{S}$ & $\begin{array}{l}\text { Water level }-3 \text { ft below } \\
\text { LSD. C,I }(04-08-76)\end{array}$ \\
\hline--- & US BLM & Y Spr. & 41-23-10bdac & $\begin{array}{r}11959.75 \\
4201.70\end{array}$ & 5200 & Tuffaceous sediments & gravity & 1 & 12 & 160 & $11-18-74$ & $\mathrm{~S}$ & $\ldots$ \\
\hline 38 & Hugh Cahill & $\cdots$ & $41 / 24-1 \mathrm{dcda}$ & $\begin{array}{r}11950.10 \\
4202.10\end{array}$ & 4510 & Landslide debris & gravity & 1 & 11 & 400 & $11-17-74$ & $\mathrm{~S}$ & $\mathrm{C}(04-07-76)$ \\
\hline$-\cdots$ & US BLM & $\begin{array}{l}\text { Spearpoint } \\
\text { Spr. }\end{array}$ & 41/24-10bdaa & $\begin{array}{r}11952.65 \\
4201.75\end{array}$ & 5460 & Tertiary basalts & gravity & $3-5$ & 9 & 260 & $11-17-74$ & $\mathrm{~S}$ & $\ldots$ \\
\hline--- & Hugh Cahill & $-\ldots$ & $41 / 24-12 c d b d 1$ & $\begin{array}{r}11950.40 \\
4201.30\end{array}$ & 4750 & Tertiary basaits & artesian(?) & $1-2$ & 6 & 220 & $11-20-74$ & $\mathrm{~s}$ &..- \\
\hline$\cdots$ & Hugh Cahill & -+- & $41 / 24-12 \mathrm{cdbd} 2$ & $\begin{array}{r}11950.40 \\
4201.30\end{array}$ & 4730 & Tertiary basalts & gravity & --- & 10 & 250 & --- & $\mathrm{S}$ & ---- \\
\hline$-\cdots$ & US BLM & --- & 41/24-13abed & $\begin{array}{r}11950.20 \\
4200.95\end{array}$ & 4755 & Tertiary basalts & gravity & 1 & 14 & 220 & $11-20-74$ & $\mathrm{~S}$ & Slight smell of $\mathrm{H}_{2} \mathrm{~S}$. \\
\hline$\cdots$ & Hugh Cahill & $-\cdots$ & 41/24-13bacb & $\begin{array}{r}11950.55 \\
4201.00\end{array}$ & 4970 & Tertiary basalts & gravity & 3-5 & 13 & 170 & $11-20-74$ & --+ & Slight smell of $\mathrm{H}_{2} \mathrm{~S}$. \\
\hline--- & Lonny Schad- & --- & 41/25-7bdab & $\begin{array}{r}11949.20 \\
4201.75\end{array}$ & 4490 & Valley-fill deposits & artesian & $2-3$ & 15 & 310 & $11-17-74$ & $\mathrm{~S}$ & -..- \\
\hline$-\ldots$ & USBLM & Jackass Spr. & 41/25-15adca & $\begin{array}{r}11945.10 \\
4200.80\end{array}$ & 5330 & $\begin{array}{l}\text { Tuffaceous sedimeats } \\
\text { (Tertiary basalts?) }\end{array}$ & gravity & 10 & 12 & 170 & $11-20-74$ & $\mathrm{~S}$ & -.-- \\
\hline$\cdots$ & US BLM & Hill Camp Spr. & 41/26-8aаaв & $\begin{array}{r}11940.35 \\
4202.00\end{array}$ & 5960 & $\begin{array}{l}\text { Tuffaceous sedimeits } \\
\text { (Tertiary basalts?) }\end{array}$ & gravity & $5-8$ & 8 & 150 & $11-23.74$ & $\mathbf{s}$ & --- \\
\hline$\cdots$ & USBLM & Tim Spr. & $41-26-18 \mathrm{bbdd}$ & $\begin{array}{r}11942.45 \\
4200.95\end{array}$ & 6480 & $\begin{array}{l}\text { Contact, Tertiary basal ts, } \\
\text { tuffaceous sediments }\end{array}$ & gravity & 0 & 4 & 160 & $11-23-74$ & $\mathrm{~s}$ & $\begin{array}{l}\text { Water level } \sim 3 \mathrm{ft} \text { below } \\
\text { LSD. }\end{array}$ \\
\hline 42 & USBLM & Gravely Spr. & $\begin{array}{l}\text { 47/18-13dadd } \\
\text { (Nevada)* }\end{array}$ & $\begin{array}{r}11954.35 \\
4159.55\end{array}$ & 5505 & Tertiary volcanic riscks & gravity & $\mathbf{0}$ & 10 & 194 & $04-07-76$ & --- & $\begin{array}{l}\mathrm{C}, \mathrm{I}(04-07-76)^{*} \text { Not on loca- } \\
\text { tion map. }\end{array}$ \\
\hline
\end{tabular}

those having temperatures greater than $20^{\circ} \mathrm{C}$, or about $11^{\circ} \mathrm{C}$ above mean annual air temperature in the valley. This definition is almost entirely arbitrary, and several springs having temperatures lower than $20^{\circ} \mathrm{C}$ may contain conductively cooled thermal water. Some springs having temperatures greater than $20^{\circ} \mathrm{C}$ may be conductively heated at shallow depths. However, most springs with temperatures of $20^{\circ} \mathrm{C}$ or greater are confirmed by chemical and isotopic evidence to have significant fractions of thermal water. The nonthermal and thermal springs range from fresh meteoric water to relatively old water derived almost directly from geothermal reservoirs. Most of the thermal waters are mixtures of these two extremes. The thermal springs especially seem to represent a fortuitous combination of circumstances involving permeable fault or fracture zones, the intersection of these zones with permeable lithologic horizons, and the mixing of deep thermal waters with shallow ground water in these zones.

Most springs have flow rates that are estimated to be less than 10 gallons per minute ( $\mathrm{gal} \mathrm{min}^{-1}$ ). Several springs in Big Valley and in the canyon of Twentymile Creek have flow rates as high as 20 to $40 \mathrm{gal} \mathrm{min}^{-1}$, but these springs are exceptional. The total flow of all 
springs inventoried is probably in the range 300 to 400 gal $\min ^{-1}$ (485 to 645 acre-ft $\mathrm{yr}^{-1}$ ). Spring discharge, therefore, is less than 1 percent of the water that enters in surface streams.

Little is known of the ground-water regime in basaltic rocks of the fault blocks adjacent to the valley and beneath the valley floor. The BLM well (sequence number 30 ) located in section 28, Township $39 \mathrm{~S}$., Range $25 \mathrm{E}$., at an altitude of 4,805 feet derives water from basaltic rocks and volcanic sediments in a raised block. The water level in this well, in September 1970, was at an altitude of approximately 4,475 feet, which is very nearly the altitude of shallow ground water in the valley about $1 \frac{1}{2}$ miles to the west.

Water levels in highlands west of the valley are probably higher than those to the east as the result of recharge from precipitation and snowmelt on the Warner Range. Most surface-water inflow to the valley enters from the west side, and this fact implies a predominance of ground-water inflow from this side. The distribution of springs in the highlands is not helpful in estimates of ground-water altitudes and flow rates because springs occur on both sides of the valley at equally high altitudes and are likely to represent only shallow perched water tables in the nearly horizontal basaltic strata.

The hydraulic conductivity and transmissivity of the rocks are not known anywhere in the area. A few data are available from which the specific capacities of wells may be calculated and transmissivities estimated. (Specific capacity equals yield divided by the drawdown of the water level during pumping.) In the sedimentary deposits, specific capacities in 11 wells ranged from approximately 1 to $60 \mathrm{gal} \mathrm{min}^{-1}$ per foot of drawdown. Applying methods described by Theis (1963) and Hurr (1966), the range of transmissivities estimated from the specific capacities is several hundred to 13,000 cubic feet per day per foot (equivalent to $\mathrm{ft}^{2} \mathrm{~d}^{-1}$ ). Most of the wells are believed to penetrate less than half the aquifer thickness, however, and many of the wells are fairly old. Thus, the observed specific capacities are probably not reliable indicators of the transmissivity of the aquifer. Lithologic logs from many wells consistently describe the sediments as predominantly fine grained and organic rich, and the average transmissivity is likely to be in the lower part of the range given above-perhaps 4,000 to 5,000 $\mathrm{ft}^{2} \mathrm{~d}^{-1}$

Transmissivities in the volcanic rocks are even more difficult to estimate than those in the valley-fill deposits. Data on discharge and drawdown are available from drillers' logs or owners' reports for eight wells in the valley that penetrate at least small thicknesses of basaltic flows and volcanic sediments beneath the val- ley fill. The wells range from large-diameter irrigation wells to small stock-watering wells. Their depths are mostly less than 250 feet. Specific capacities range from about 3 to several hundred gal $\mathrm{min}^{-1}$ per foot of drawdown, indicating that apparent transmissivities are in the range 800 to $55,000 \mathrm{ft}^{2} \mathrm{~d}^{-1}$. These wells penetrate no more than a few tens of feet of volcanic rock, however, and the water-bearing formations appear to be mostly volcanic sediments and breccias. Data from these wells probably are not representative of conditions in the deeper basaltic aquifers.

The volcanic formations in the area appear to be similar in most respects to formations near Klamath Falls, where data are available from about 140 wells completed in basaltic flow rocks and volcanic sediments (Sammel, 1980). Assuming that the hydraulic characteristics of the Warner Valley rocks are similar to those in the Klamath Falls area, average transmissivity in tuffs and tuffaceous sediments is estimated to be about $8,000 \mathrm{ft}^{2} \mathrm{~d}^{-1}$ and in the basaltic flow rocks, about $10,000 \mathrm{ft}^{2} \mathrm{~d}^{-1}$.

Flow paths of ground water in the area have not been accurately determined. Probable patterns of flow can be deduced, however, from measurements of static heads in wells and from some of the chemical data.

Within the valley-fill deposits, water probably moves upward from the bedrock and laterally from the valley walls as the result of the presumably higher potentiometric heads in the adjacent highlands. Artesian heads observed in several deep wells and highly permeable zones penetrated by wells in bedrock aquifers near the valley walls indicate that such flow must occur. The artesian heads are generally no more than 10 or 15 feet above normal hydrostatic heads, however, and the amount of flow may be rather small.

Chemical analyses of water from one drill hole, MC2, located near the south end of Warner Valley, show that water having the characteristics generally found in bedrock aquifers moves upward more than 200 feet into the unconsolidated deposits at this site (table 3). A significant amount of ground-water recharge may occur, therefore, at the base of the valley-fill deposits if conditions at $\mathrm{MC} 2$ are prevalent.

Throughout most of the thickness of the valley-fill deposits, ground-water flow is toward the north with a gradient that is probably similar to the surface-water gradient of about 0.8 feet per mile.

The water table forms a generally uniform surface which is interrupted only by a ground-water mound within the former delta of Deep Creek, near Adel. Unconfined ground water in the deltaic deposits has static heads as much as 70 feet above levels in adjacent valley-fill deposits, and hydraulic gradients directed away from the delta are as high as 40 feet per mile. 
At the north end of Warner Valley, much of the ground water is discharged by evapotranspiration. Irrigation from large wells in this area contributes to the evaporative discharge, but most of the water probably evaporates from lake and swamp surfaces.

Ground water probably flows out of Warner Valley toward the topographically low area surrounding Harney Lake, about 10 miles to the north. Much of the flow may occur in a thick section of tuffaceous sediments and welded tuffs that cover the older Tertiary volcanic rocks north of Warner Valley (Walker and Repenning, 1965; Greene and others, 1972).

A crude estimate of ground-water discharge can be made on the basis of an assumed hydraulic gradient and an estimate of transmissivity in the region north of Warner Valley. The average hydraulic gradient between the north end of Warner Valley and Harney Lake is on the order of 0.007 . Transmissivity in the welded tuffs and tuffaceous sediments is estimated to be in the range 5,000 to $8,000 \mathrm{ft}^{2} \mathrm{~d}^{-1}$. If most of the flow is assumed to occur through an 8-mile wide section of rock below the 4,500-foot altitude contour north of Bluejoint Lake, the total annual ground-water outflow is calculated to be in the range 12,000 to 20,000 acre-ft. This estimate may contain large errors, but it seems certain that ground-water discharge is a small fraction of the total recharge from streamflow and precipitation.

\section{QUALITY OF WATER}

\section{QUALITY OF SURFACE WATER}

The chemical quality of water in the perennial streams that enter the valley is excellent, as would be expected of water that originates as precipitation on the Warner Range only a few tens of miles west of the valley. The data in table 5 and the Stiff diagrams in plate 1 show that the waters in Deep Creek, Twentymile Creek, and Honey Creek are mildly bicarbonate waters in which calcium concentrations slightly exceed concentrations of sodium and magnesium. The concentration of dissolved solids is less than 200 milligrams per liter $\left(\mathrm{mg} \mathrm{L}^{-1}\right)$.

As the water moves downgradient (northward) in Deep Creek and into the chain of lakes that form the channel in much of the area north of Adel, dissolved solids increase and sodium becomes the dominant cation. Some of the added constituents, particularly solids increase and sodium becomes the dominant cation. Some of the added constituents, particularly sodium and nitrogen, are probably derived from fertilizers used in the valley. Much of the increase in dissolved solids, however, is due to natural constituents dissolved by ground water from the valley-fill deposits. Finally, evaporation from lakes and the shallow water table and the addition of water from thermal springs add to the concentrations of dissolved solids in the surfiace waters.

\section{QUALITY OF GROUND WATER}

Shallow ground water in the Warner Valley area is generally of good to excellent quality. Concentrations of dissolved solids are mostly less than $300 \mathrm{mg} \mathrm{L}^{-1}$ (table 6). Waters having temperatures less than $10^{\circ} \mathrm{C}$ are of excellent quality and are chemically similar to stream waters entering the valley. The coldest waters are found in gravity springs located in the highlands. They are mildly calcium bicarbonate to sodium kicarbonate-type waters.

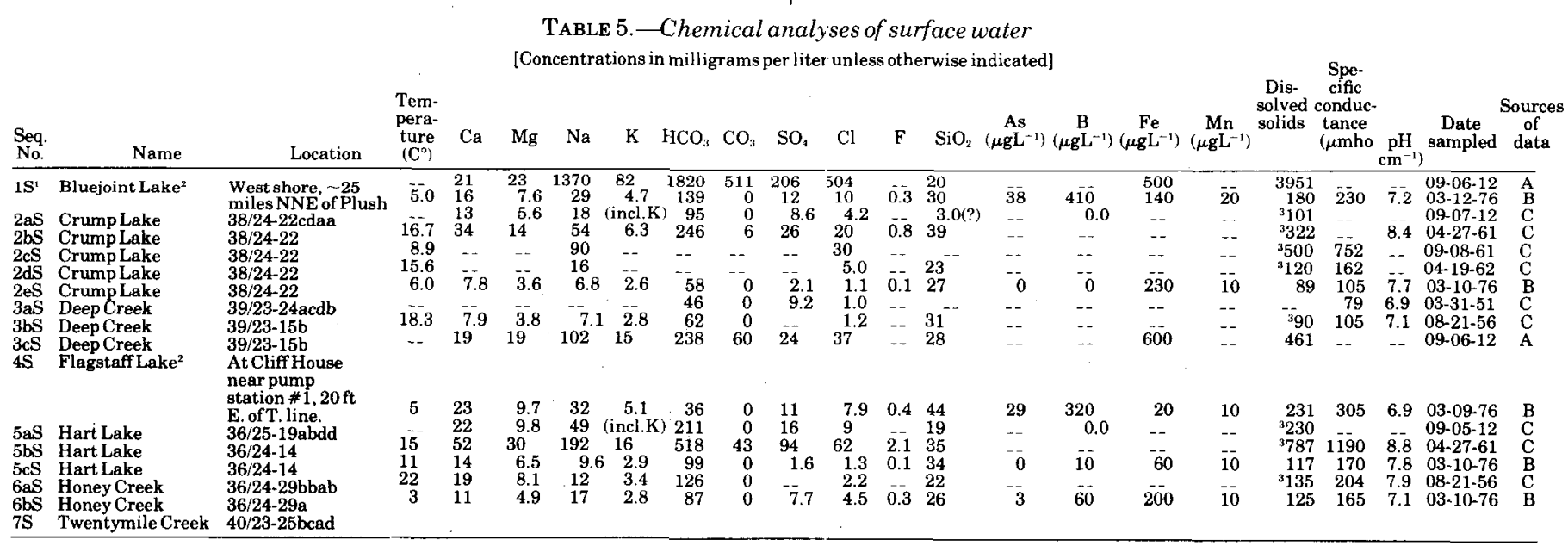

Sources of data:

A. Van Winkle (1914)

B. E. A. Sammel and N. E. Voegtly.
C. Phillips and Van Denburgh (1971)

'Sequence numbers of surface waters are identified with an " $S$ " symbol.

${ }^{2}$ Not in area covered by this report. Data has been included for comparison.

${ }^{3}$ Estimated by summation of $\mathrm{HCO}_{3} \times 0.4917$ and other ions listed (Hem, 1970). 
TABLE 6. - Chemical analyses of water from wells and springs [Concentrations in milligrams per liter unless otherwise indicated]

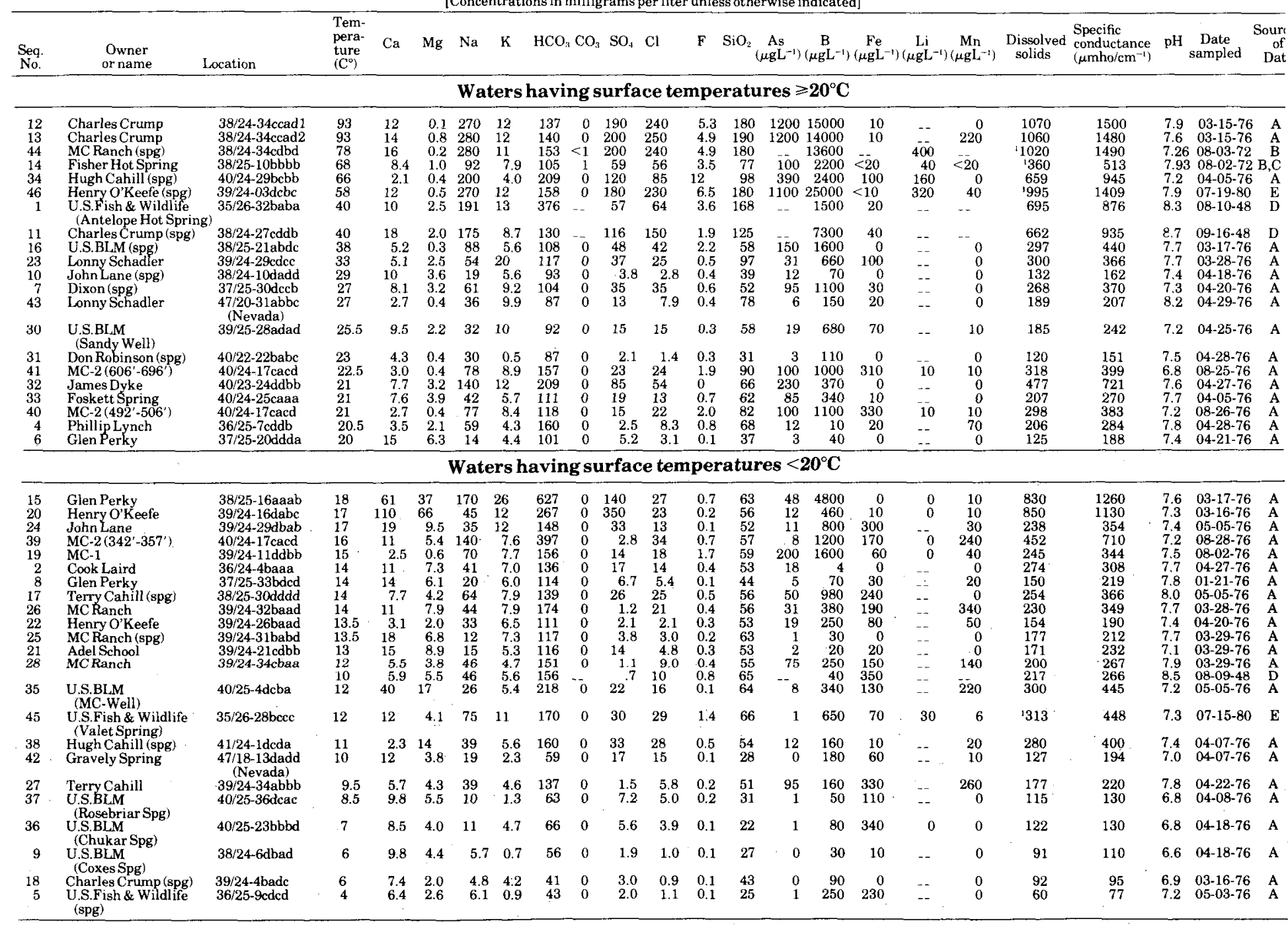

Sources of data:

A. E. A. Sammel and N. E. Voegtly.
B. R.H.Mariner, and others (1974).

C. R. H. Mariner, and others (1975)

D. Trauger (1950)

E. E.A. Sammel and R. W. Craig.

Estimated by summation of $\mathrm{HCO}_{3} \times 0.4917$

and other ions listed (Hem, 1970).

Within the valley, most nonthermal waters have temperatures in the range $10^{\circ} \mathrm{C}$ to $16^{\circ} \mathrm{C}$. Their contact with the basin sediments is reflected in concentrations of major ions that are high relative to the cold spring waters from the highlands. Sodium and bicarbonate are the predominant ions.

The chemical contents of the colder waters of the Warner Valley area correspond to those found in waters throughout the Lava Plateau region, as documented by Klein and Koenig (1977). According to these authors, cold spring waters having temperatures less than the mean annual air temperature are characterized by sodium, calcium, and magnesium concen-

trations which are generally less than $10 \mathrm{mg} \mathrm{L}^{-1}$ each. Sulfate and chloride concentrations are generally less than $2 \mathrm{mg} \mathrm{L}^{-1}$. Bicarbonate concentrations range from 41 to $66 \mathrm{mg} \mathrm{L}^{-1}$. Silica concentrations are generally less than $30 \mathrm{mg} \mathrm{L}^{-1}$, but range to more than $40 \mathrm{mg} \mathrm{L}^{-1}$. The chemical similarity between the colder waters of Warner Valley and the regional pattern is probably the result of two factors: the region's widespread volcanic rocks which provide a generally similar chemical basis for water-rock interactions, and the relatively short residence times of the waters in the rocks which minimizes the effect of the water-rock reactions.

In the discussion that follows and throughout the remainder of this report, the sequence number assigned to each ground-water sample taken for chemical analysis is used interchangeably to refer to both the sample and to the spring or well from which it came. Locations and other data for these springs and wells 
may be found by referring to the sequence numbers in tables 3 and 4 .

Thermal waters in the study area range from sodium bicarbonate waters at low temperatures to sodium chloride waters at higher temperatures. The hotter waters contain the highest measured concentrations of sodium, chloride, sulfate, and silica. Three samples of this type of water were obtained in the Crump geyser area, located on the west side of the valley north of Adel. Samples 12, from a 121-foot well, and 44, from a nearby spring, have temperatures of $93^{\circ} \mathrm{C}$ and $78^{\circ} \mathrm{C}$ respectively. The waters have virtually identical chemical compositions and are clearly derived from the same parent water (pl. 1 and fig. 4). The third sample, number 13 , is from a 1,684-foot well located only 140 feet from well 12. Most of the constituents in sample 13 have slightly higher concentrations relative to sample 12. Boiling observed at the water surface in well 13 may have concentrated the dissolved constituents.

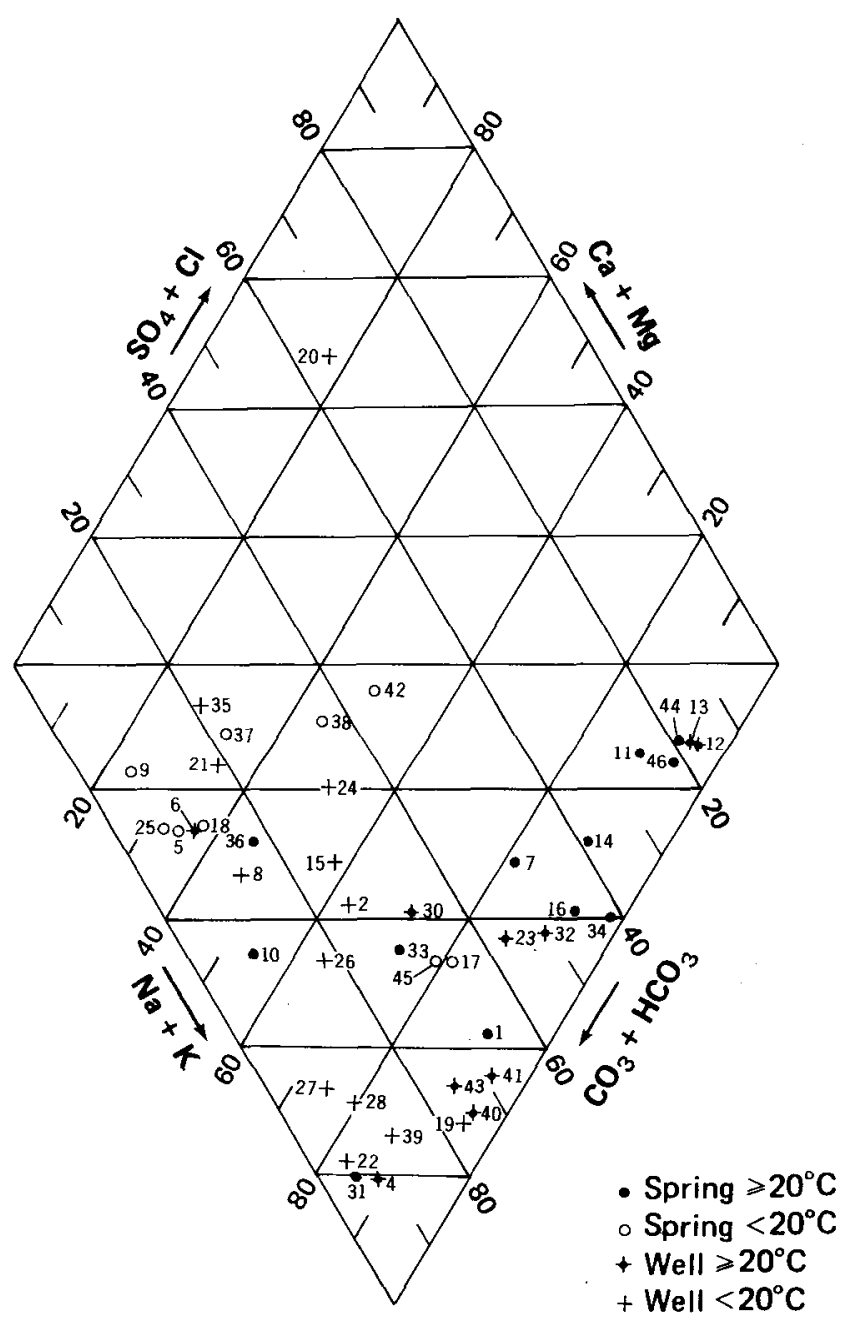

Figure 4.-Piper diagram of chemical relations in water from wells and springs: percentage reacting values.
Sample 11, from a spring located approximately a mile north of Crump geyser, is also a sodium chloride water. Chemically it is a dilute version of the Crump geyser waters and is clearly related.

In the remaining thermal waters, with temperatures in the range of $20^{\circ} \mathrm{C}$ to $68^{\circ} \mathrm{C}$, sodium and chloride generally increase with respect to calcium and bicarbonate as temperatures increase (table 7). The increasing sodium and chloride concentrations probably represent increased proportions of thermal water.

The two hottest waters in the latter group are Fisher Hot Spring (sample 14), located about 4 miles north of Crump geyser on the east side of the valley, which has a surface temperature of $68^{\circ} \mathrm{C}$, and a large seep at the south end of Warner Valley (sample 34), with a temperature of $66^{\circ} \mathrm{C}$. Cooler waters of this type are scattered throughout Warner Valley and Coleman Valley. The relationship between these waters and the waters of the Crump geyser area is discussed in subsequent sections of this report.

Concentrations of fluoride are high in most of the thermal waters, ranging from 1.9 to $12 \mathrm{mg} \mathrm{L}^{-1}$ in waters warmer than $40^{\circ} \mathrm{C}$. The fluoride concentrations vary greatly and are not closely correlated with concentrations of more stable ions such as chloride (fig. 5). The high concentration of fluoride in sample $34,12 \mathrm{mg}$ $\mathrm{L}^{-1}$, may be related to the unusually low concentration of calcium in this water, $2.1 \mathrm{mg} \mathrm{L}^{-1}$, which is the lowest concentration observed in a ground-water sample in Warner Valley. The calcium concentration is approximately the amount required for equilibration with the mineral fluorite $\left(\mathrm{CaF}_{2}\right)$ which is commonly found in volcanic terranes (Hem, 1970). This relationship is not typical of thermal waters in Warner Valley however.

Sample 20 , obtained at $17^{\circ} \mathrm{C}$ from a 360 -foot well located about $1 / 2$ mile south of Crump geyser, may have an admixture of thermal water but is anomalous with respect to its high concentrations of calcium, magnesium, and sulfate (fig. 4). The specific conductance,

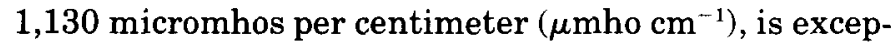
tionally high for a low-temperature water.

Silica and chloride concentrations are useful in some areas for determining possible mixing trends in thermal waters. (See Sammel, 1980.) Chloride concentrations acquired at high temperatures in geothermal reservoirs tend to remain constant as the waters ascend to the surface unless the water has boiled or is diluted by shallow ground water. If the cooling waters do not become saturated with respect to amorphous silica, the silica concentrations also may remain rather stable. Thus, if variations in these two constituents can be attributed solely to mixing, they may be used to determine the amount of mixing that has occurred.

A graph of chloride concentration versus temperature in the thermal waters (fig. 6) shows that chloride 
TABLE 7.-Molal ratios of selected dissolved constituents in ground water

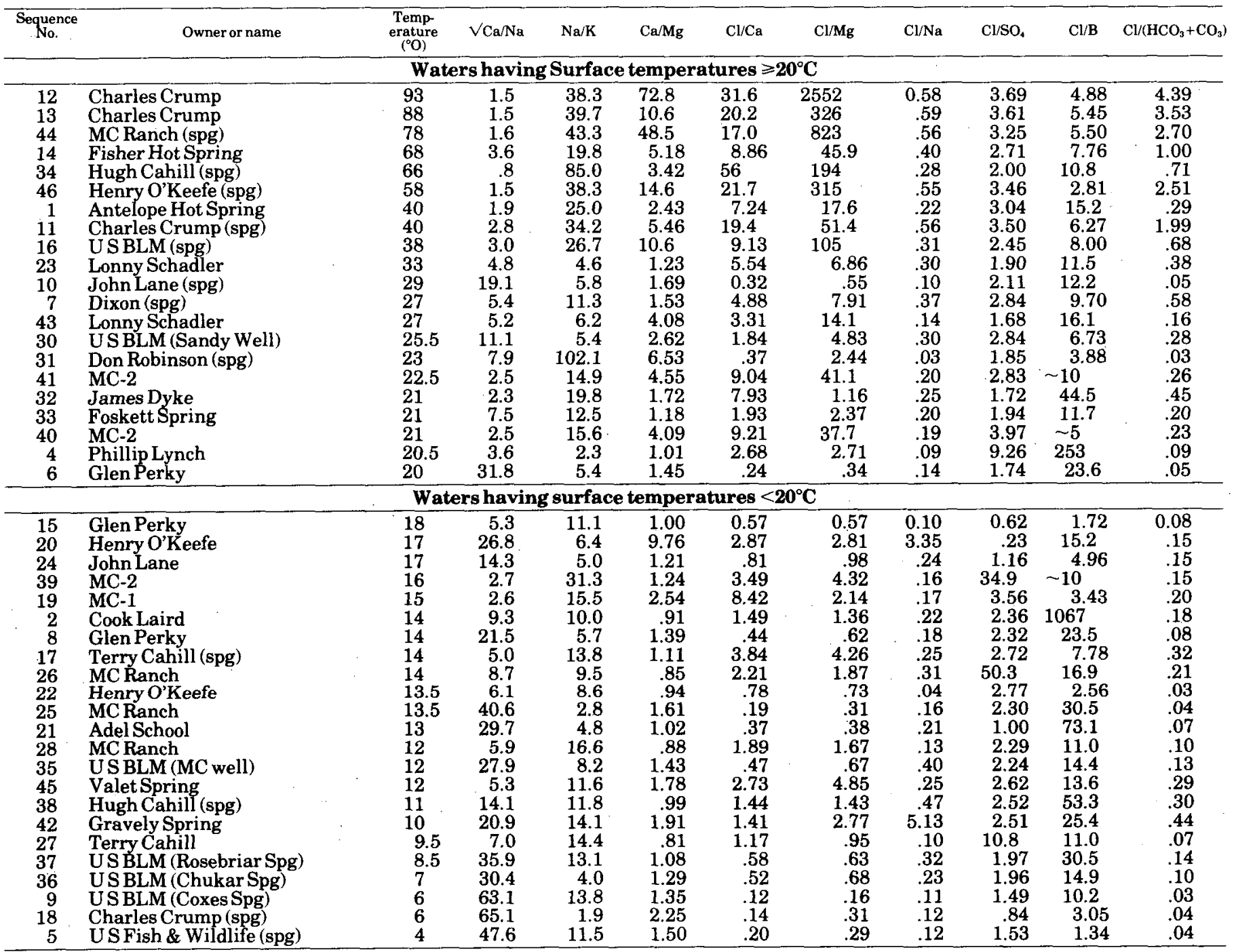

generally increases with increasing temperature. Because chloride concentrations are fairly uniform in the colder waters (represented by the triangular point in fig. 6) and in the hotter waters (samples 12,13 and 44), mixing of waters from these two groups should produce a linear trend for waters of intermediate composition. The scatter in the data suggests, however, that factors other than simple mixing of hot and cold waters are important in determining the temperatures of many of the low-temperature waters. Conductive heat loss may explain some of the temperature differences, and this mechanism is invoked in a subsequent section of the report ("Temperatures in the Geothermal Reservoir") in order to account for the observed temperatures of Fisher Hot Spring and several other waters.

Silica concentrations. in the thermal waters generally increase with increasing chloride concentration, and a graph of silica versus chloride (fig. 7) suggests that both of these constituents might be used with some confidence in mixing models. A dilution trend is clearly indicated by line $\mathrm{A}$ in figure 7 . Trend A contains all but two of the thermal waters having temperatures greater than $30^{\circ} \mathrm{C}$. The exceptions are samples 1 and 23. Sample 1 (Antelope Hot Spring) has an exceptionally large silica concentration in relation to its temperature and chloride concentration. This spring occurs at a much higher altitude than other thermal springs $(6,000$ feet versus 4,500 feet for springs on the valley floor), and its relationship to other thermal waters is uncertain. Sample 23 was obtained from a rarely used well of unknown depth located near the west valley wall south of Adel. The silica concentration is anomalously high in relation to the dissolved-solids concentration and concentrations of other major ions.

Exceptions to the trend of line $\mathrm{A}$ at temperatures below $30^{\circ} \mathrm{C}$ are samples from wells 4,43 , and $\mathrm{MC2}$ (samples 40 and 41). These waters, with samples 1 and 23 , may define a separate mixing trend, line $B$ in figure 
7 , or, more probably, may have increased their silica concentrations by dissolving amorphous silica from the valley-fill deposits or bedrock.

The low-concentration end point in figure 7 , shown by the open triangle, represents the average concen-

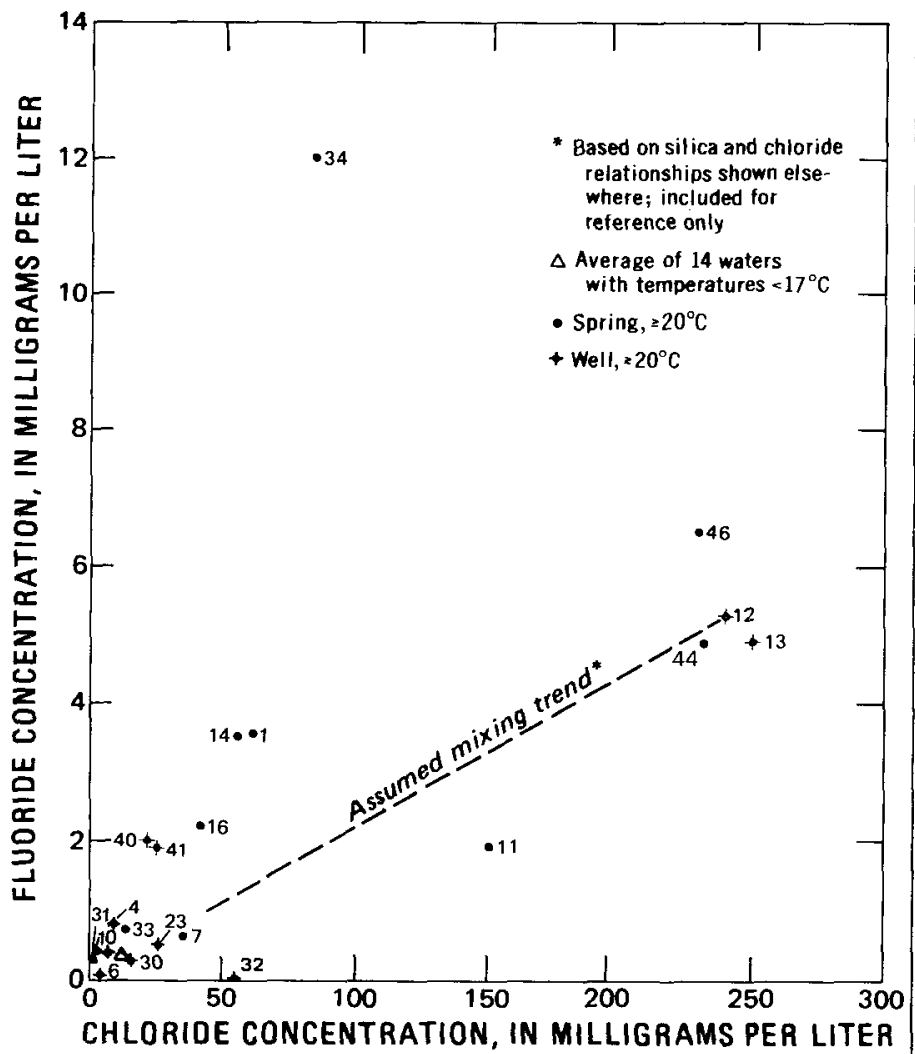

Figure 5.-Graph of chloride concentration versus fluoride concentration in ground water. The assumed mining trend is based on silica and chloride relationships shown elsewhere and is included for reference only

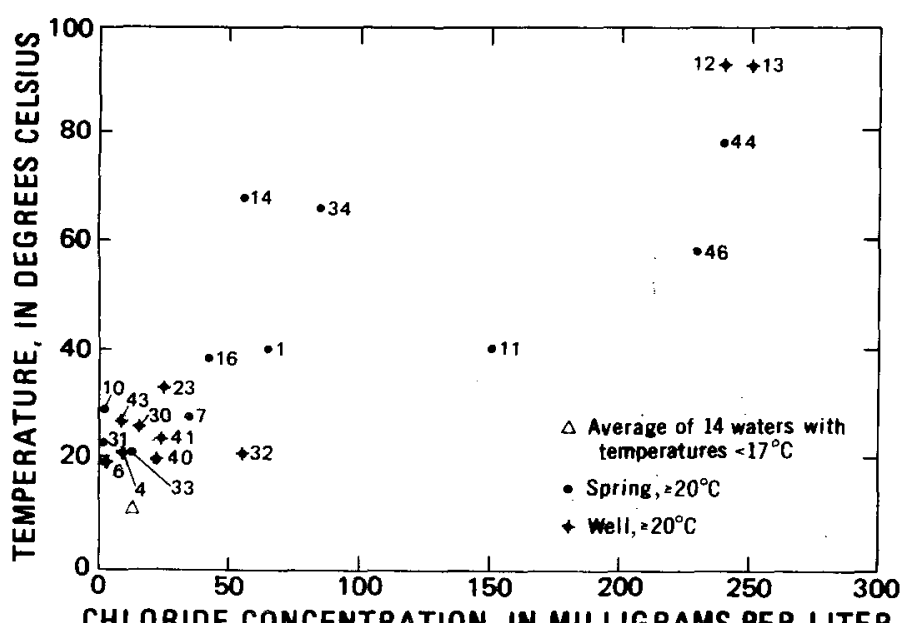

Figure 6.-Graph of chloride concentration versus temperature in ground water. trations of silica and chloride in 14 low-temperature waters from Warner Valley. The average concentrations of silica, chloride, and dissolved solids in these waters fit well in mixing models described in a sequent section of this report. Hence, these average concentrations are assumed to be close to actual concentrations in the recharge waters of the area. The 14 waters selected do not include 6 dilute cold waters from springs located on raised fault blocks adjacent to the valley. Although the waters of these springs may be typical of upland recharge sources, their chemical compositions generally do not fit the geothermal mixing models as well as do the compositions of waters that have circulated more deeply and have acquired slightly higher temperatures and concentrations of dissolved solids. The implications of this fact are discussed further in the section entitled "Temperatures in the Geothermal Reservoir."

A further evaluation of the usefulness and reliability of the silica and chloride concentrations as geothermal indicators may be made with the help of graphs such as those shown in figures 8 and 9 . In these graphs, concentrations of chloride, silica, and bicarbonate are plotted as ratios versus the chloride concentration. As compared with simple two-parameter graphs, such as figures 5,6 , and 7 , ratio plots may convey additional information insofar as the direction and magnitude of changes in the ratio of the two parameters are significant. As in figures 5,6 , and 7 , separate data points are given for each thermal water $\left(\geqslant 20^{\circ} \mathrm{C}\right)$ and a single point represents a probable average lowtemperature recharge water. In both graphs, a dashed

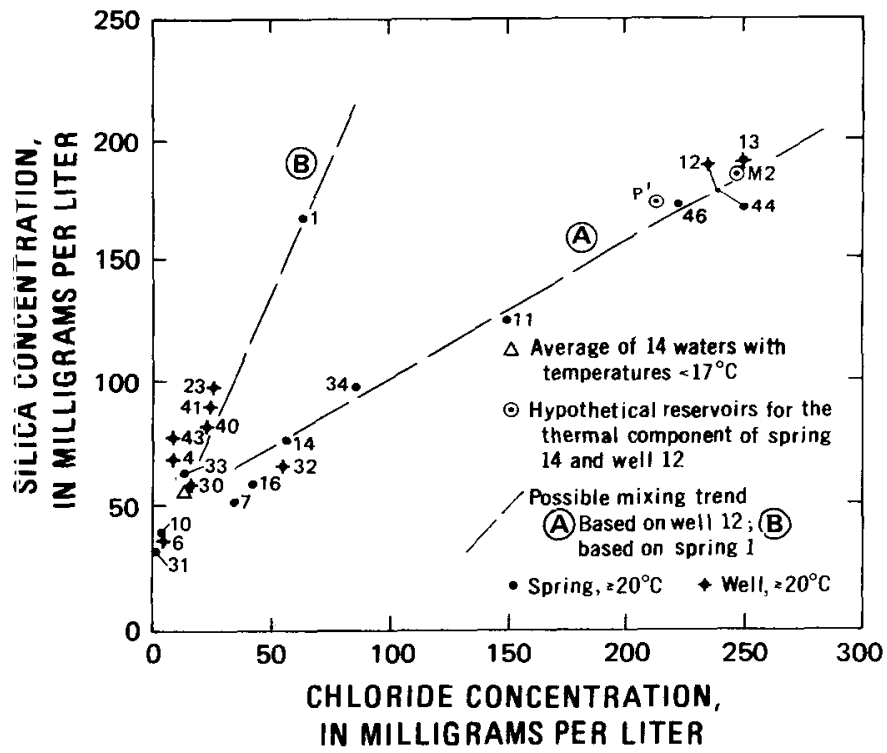

FIGURE 7.-Graph of chloride concentration versus silica concentration in ground water and hypothetical reservoir water. 
line indicates the curve that would be followed if the average cold recharge water were mixed in all proportions with a hot water represented either by sample 12 (fig. 9), or by a hypothetical reservoir water (fig. 8). The concentrations of silica and chloride in the reservoir water were estimated by means of silica-enthalpy and chloride-enthalpy diagrams discussed in the section of this report entitled "Temperatures in the Geothermal Reservoir."

The graph of figure 8 shows that the ratio of chloride to silica is much lower in the presumed recharge water than in the hotter geothermal waters. This is the result of the relatively high solubility and the general availability of amorphous silica at shallow depths in volcanic terranes. Chloride, on the other hand, is not readily available to the shallow ground waters of Warner Valley, and concentrations greater than about $20 \mathrm{mg}$ $\mathrm{L}^{-1}$ probably indicate the presence of a thermal-water component.

In the thermal-reservoir water, the high ratio of chloride to silica reflects the limiting of silica concentrations by the temperature-dependent solubility of quartz (Fournier, 1973), whereas the chloride concentration is limited only by the availability of chloridebearing minerals and residence time. The high concentrations of chloride in the hotter waters indicate that

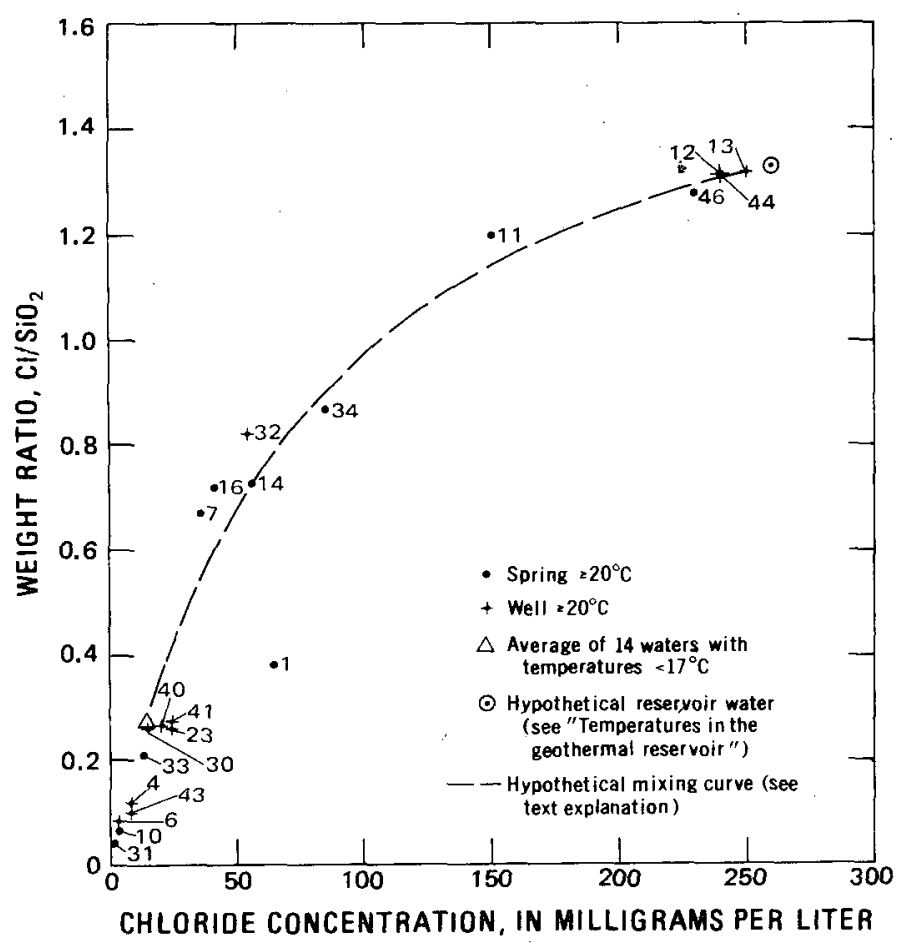

FIGURE 8.-Graph of the weight ratio $\left(\mathrm{Cl} / \mathrm{SiO}_{2}\right)$ versus chloride concentration in ground water. chloride is available to the thermal waters and that the residence times are fairly long.

The reasonably close fit of the intermediate data points to the hypothetical mixing curve in figure 8 indicates that simple mixing of reservoir water with recharge water could account for the observed silica and chloride concentrations in most of the moderatetemperature waters. The fit would be slightly better if the water of well 12 were used as the high-temperature end point, but the small difference may be due to analytical imprecision and is probably not significant. At the steeply-sloped low-chloride end of the curve, some scatter occurs which is partly masked by the relative independence of the chloride-silica ratio from the chloride concentration. Only the data point for spring 1 (Antelope Hot Spring) is clearly anomalous, however, and there is little suggestion of the double mixing trends that appear when the silica and chloride concentrations are plotted as in figure 7.

The ratio of equivalents chloride to equivalents $\left(\mathrm{HCO}_{3}+\mathrm{CO}_{3}\right)$ can be useful in distinguishing waters of differing thermal aquifers (Fournier and Truesdell, 1970; White, 1970). Concentrations of $\left(\mathrm{HCO}_{3}+\mathrm{CO}_{3}\right)$ in thermal waters may be established by temperaturedependent reactions involving the partial pressure of $\mathrm{CO}_{2}$ gas and sodium or potassium silicates, all of which commonly occur in hydrothermal environments. To the extent that these constituents are uniform within an aquifer and vary between aquifers, the equivalent $\mathrm{Cl} / \mathrm{HCO}_{3}+\mathrm{CO}_{3}$ ) ratio will be distinctive for a given aquifer and may be retained for some time in the near-surface environment (Fournier and Truesdell, 1970). Mixing of thermal water with shallow water

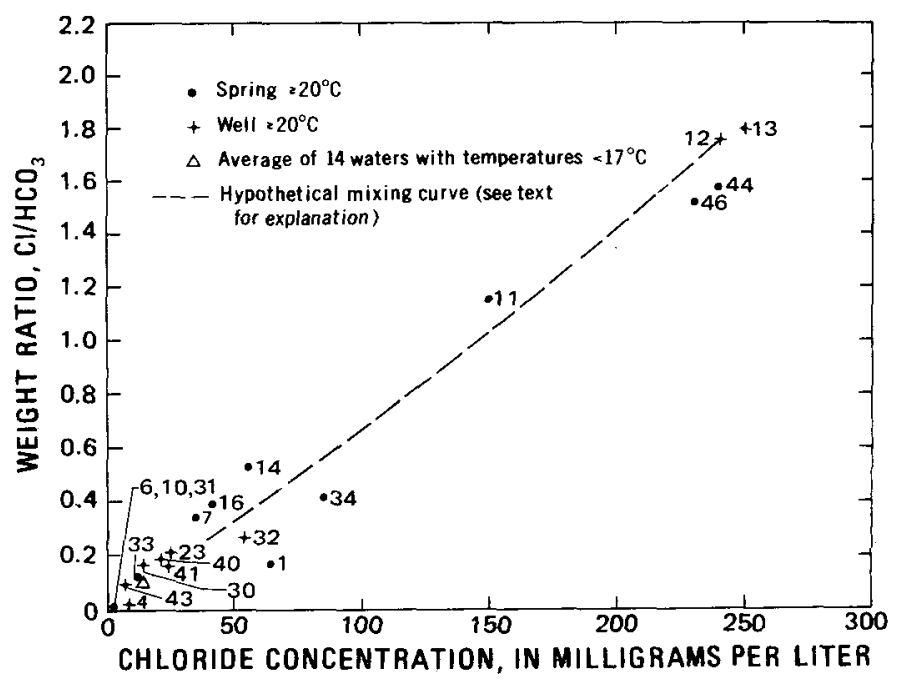

FIGURE 9.-Graph of the weight ratio $\left(\mathrm{Cl} / \mathrm{HCO}_{3}\right)$ versus chloride concentration in ground water. 
having a different $\mathrm{Cl} / \mathrm{HCO}_{3}+\mathrm{CO}_{3}$ ) ratio will obviously result in ratios intermediate between the two.

For the Warner Valley waters, the atomic ratio $\mathrm{Cl} /$ $\mathrm{HCO}_{3}$, is used in figure 9 in place of the equivalent $\mathrm{Cl} / \mathrm{HCO}_{3}+\mathrm{CO}_{3}$ ) ratio because only two of the waters contain $\mathrm{CO}_{3}$ and the concentrations of this ion are $1 \mathrm{mg}$ $\mathrm{L}^{-1}$ or less. The graphical relations are virtually identical to those that would be shown by the equivalent $\mathrm{Cl} /\left(\mathrm{HCO}_{3}+\mathrm{CO}_{3}\right)$ ratio.

The change in the $\mathrm{Cl} / \mathrm{HCO}_{3}$ ratio shown in figure 9 between the high-chloride (hot) waters and the lowchloride (cooler) waters clearly indicates that the two extreme groups of waters represent differing chemical regimes. As is true for the chloride-silica relation (fig. 8) the most reasonable explanation for the distribution of intermediate data points appears to be mixing of the end-member waters.

The hypothetical mixing curve based on sample 12 as the high-chloride end point probably accounts fairly well for the composition of spring 11, a spring of moderate temperature located 1 mile north of Crump geyser. The scatter of data points near the low-chloride end of the curve may be the normal effect of a heterogeneous environment such as Warner Valley. It seems equally probable, however, that some of the departures from values predicted by the mixing curve represent differing mixing trends. It may be significant, for example, that three warm springs located near the north end of Crump Lake (samples 7, 14, and 16) have uniformly higher bicarbonate concentrations than predicted, whereas a well and a spring located in the south end of Warner Valley (samples 32 and 34) have lower than expected bicarbonate concentrations. A sixth sample (1), from Antelope Hot Spring, has a position with respect to the mixing curve that is similar to its position in figure 9 and which seems clearly anomalous.

In the absence of additional high-chloride waters that might help to establish possible origins in separate reservoirs, no firm conclusions regarding precise mixing trends can be reached on the basis of figures 8 and 9. Additional evidence is discussed in the section of the report entitled "Temperatures in the Geothermal Reservoir."

Several general conclusions about the origin and nature of the thermal waters in Warner Valley may be drawn from the chemical data. It seems certain, for example, that the thermal waters originate in a hotwater system rather than a vapor-dominated system. The occurrence of high concentrations of alkali chlorides, silica, boron, and arsenic in waters of nearneutral $\mathrm{pH}$ support this conclusion (White and others, 1971). Ratios of major ions (shown in table 7) also support the concept of a hot-water system. Fairly high ratios of $\mathrm{Ca} / \mathrm{Mg}, \mathrm{Cl} / \mathrm{Mg}$, and $\mathrm{Cl} /\left(\mathrm{HCO}_{3}+\mathrm{CO}_{3}\right)$ and low ratios of $\mathrm{Ca} / \mathrm{Na}$ in the hotter waters are typical of hydrothermal systems having moderately high reservoir temperatures (White, 1970; Mahon, 1970; Ellis, 1970). Adiabatic cooling of the hot waters as they ascend to the surface would not greatly change the relations among major ions such as silica, chloride, sodium, and sulfate.

Extensive sinter deposits observed in two thermal discharge areas north of Adel (pl. 1) indicate that the thermal waters have had temperatures that may have been as high as $180^{\circ} \mathrm{C}$ (White and others, 1971). Field observations indicate that silica is still being deposited in these areas.

Finally, all thermal waters in Warner Valley are assumed to be mixtures of hot waters and cooler recharge waters. This conclusion is not well substantiated by the data presented thus far, but it is supported by the graphs of temperature versus chloride, chloride versus silica, and chloride versus bicarbonate (figs. 6-9).

\section{ISOTOPES IN GROUND WATER}

Twenty-nine samples of water from the Warner Valley area were analyzed for stable isotopes of oxygen $\left({ }^{18} \mathrm{O}\right)$ and hydrogen (deuterium). Samples were taken from a wide range of waters in the study area in order to provide information on background concentrations as well as concentrations in the thermal waters. Results of the analyses are shown in table 8 .

The amounts of ${ }^{18} \mathrm{O}$ and deuterium, $\mathrm{D}$, in precipitation decrease with altitude and other factors in a manner that is approximated by the expression, $\delta \mathrm{D}=8 \delta^{18} \mathrm{O}$ +10 , where $\delta \mathrm{D}$ and $\delta^{18} \mathrm{O}$ are ratios of these isotopes to ${ }^{1} \mathrm{H}$ and ${ }^{16} \mathrm{O}$, respectively, expressed in parts per thousand (per mil) as departures from the ratios in standard mean ocean water (SMOW) (Craig, 1961). ${ }^{1}$ The "meteoric line" resulting from the above expression is shown in figure 10 , along with data from the springs and wells in the Warner Valley area.

Samples numbered 5, 9, and 37 in figure 10 are from cold springs at high altitudes. The data points are roughly parallel to, but offset from, the meteoric line. The position of sample 18, from a cold, high-altitude spring, and sample 19, a cold water from a depth of approximately 400 feet in a GS heat-flow hole (MC1), are anomalous but are within the limits of analytical error.

The hottest waters, samples 12,13 , and 44 , show an enrichment in ${ }^{18} \mathrm{O}$ of at least 2 per mil relative to the colder waters. The increase is presumably due to isotope exchange reactions between water and rock

\footnotetext{
1 For a more complete description of the application of isotope analyses to geothermal investigations see, for example, Coplen (1976).
} 


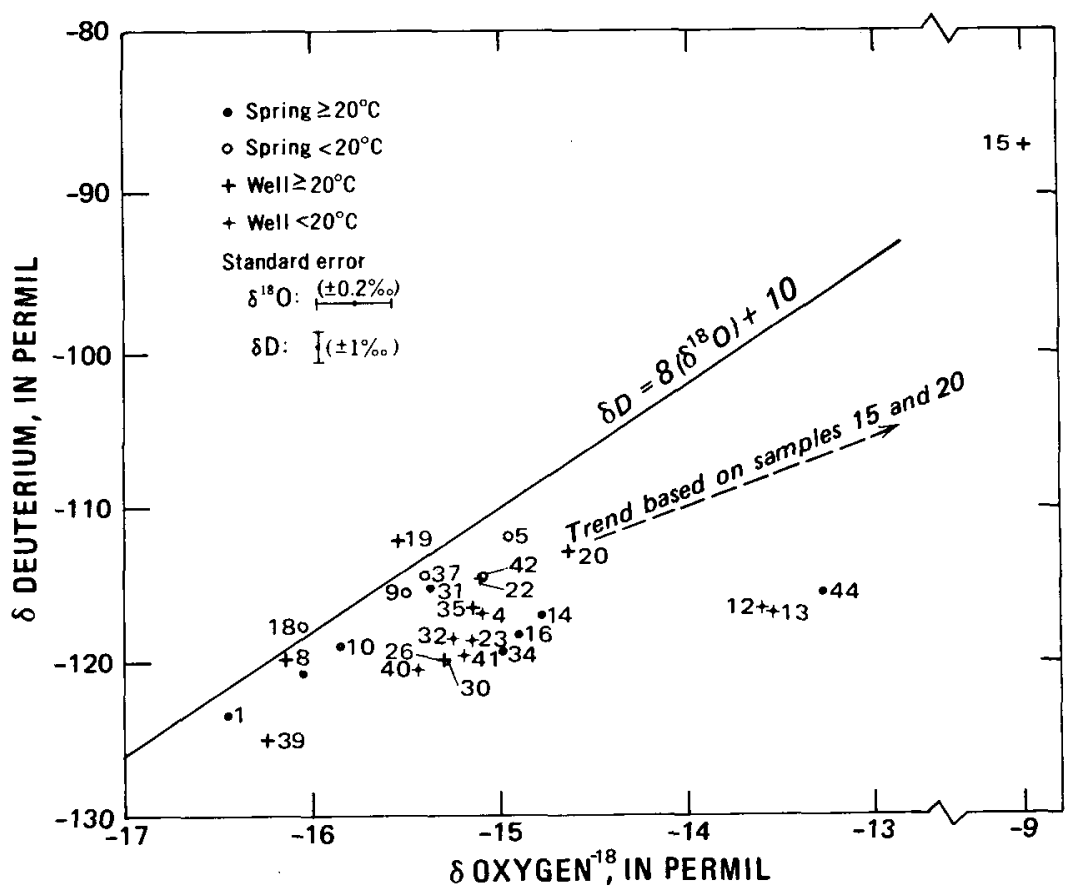

FIGURE 10.-Graph of $\delta^{18} \mathrm{O}$ versus $\delta \mathrm{D}$ in ground water as departures, in parts per thousand, from standard mean ocean water (Craig, 1961).

TABLE 8.-Isotopes of oxygen $\left({ }^{18} \mathrm{O}\right)$ and hydrogen (deuterium and tritium) in ground water

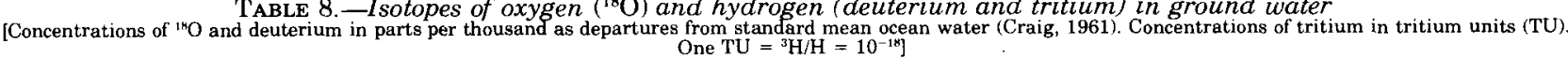

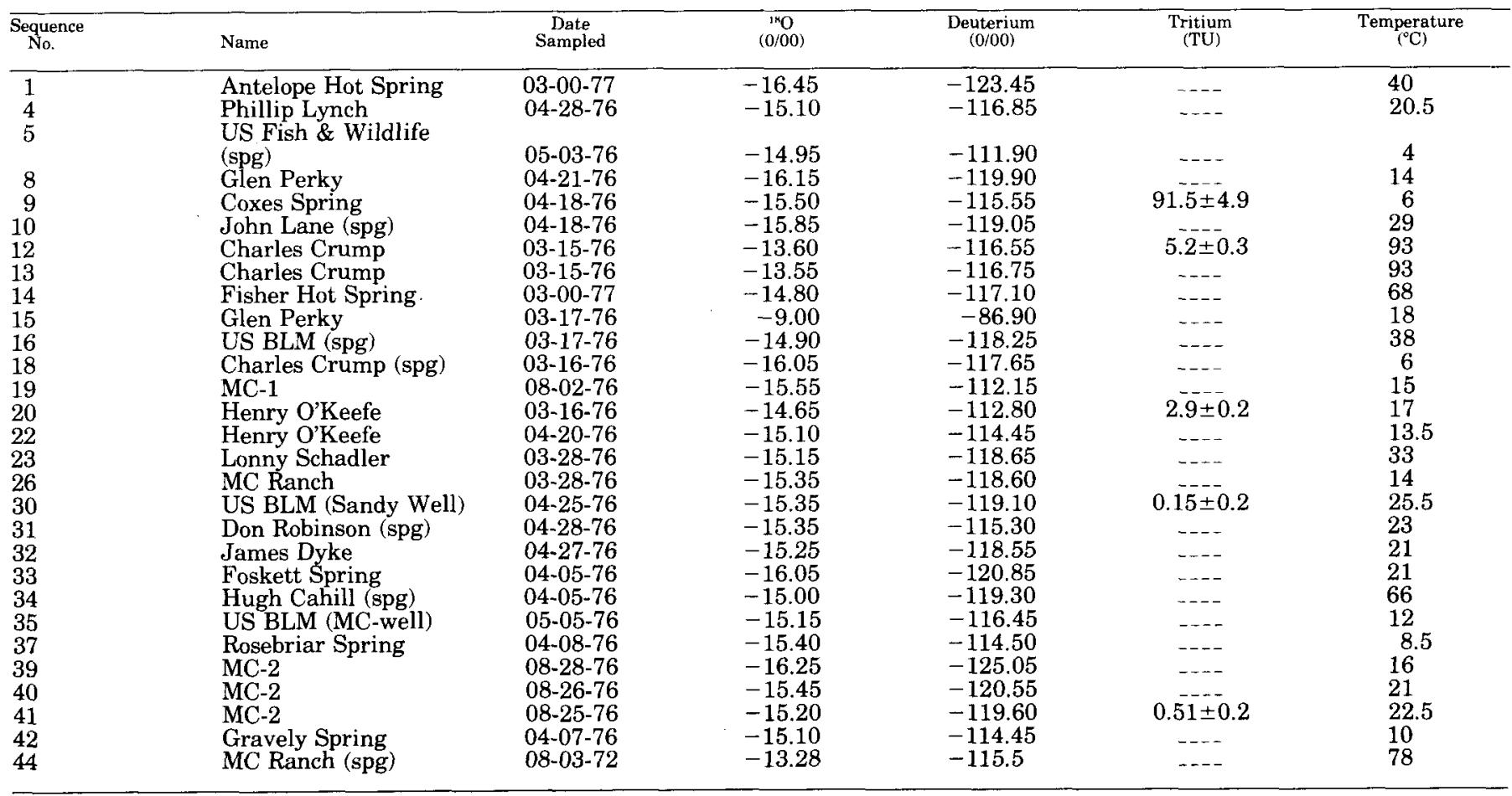


oxygen in a reservoir that is deeper and hotter than the shallow aquifers. The amount of ${ }^{18} \mathrm{O}$ enrichment in these waters may be compared to increases of 1.4 per mil in hot waters at Klamath Falls, Oreg. (Sammel, 1980), and as much as 3-5 per mil in a hightemperature system such as Steamboat Springs, Nev. (White, 1968).

Sample 15 , with a temperature of $18^{\circ} \mathrm{C}$, was obtained in a 90 -foot well located on the east side of Warner Valley and is clearly anomalous in relation to other waters in the area. Its position on the graph coincides, however, with a trend for warm waters of the Klamath Hills area, near Klamath Falls, in which chemical and isotopic compositions are, for the most part, similar to those of sample 15 (Sammel, 1980).

Low-temperature evaporation has been invoked in order to explain the characteristics of the Klamath Hills waters. This explanation does not satisfactorily account for the chemical nature of sample 15 . Concentrations of dissolved solids and of the major ions, Ca, $\mathrm{Mg}, \mathrm{Na}, \mathrm{K}, \mathrm{HCO}_{3}$, in sample 15 are from four to six times the mean concentrations of these ions in $18 \mathrm{sam}$ ples of water from Warner Valley having temperatures between $10^{\circ} \mathrm{C}$ and $20^{\circ} \mathrm{C}$. This apparent uniformity of change suggests evaporation as a mechanism. However, concentrations of silica and chloride in sample 15 are low, respectively 1.1 and 2 times concentrations in the 18 other waters. As silica and chloride are expected to be conserved during evaporative concentration, this mechanism does not satisfactorily account for their low values. An alternative explanation is that the high concentrations of constituents were acquired by solution of minerals in an atypical zone of the aquifer. This explanation could account for the chloride concentration which would not necessarily be greatly increased by solution of the valley-fill deposits, but the low silica concentration would still be difficult to explain. The question remains unresolved, but the explanation, if obtained, may also account for the reported chemistry of sample 20, from a 109-foot well near Adel, which has the same temperature and nearly the same dissolved solids concentration as sample 15 , although greatly differing ratios of major ions. Sample 20 also shows an enrichment in ${ }^{18} \mathrm{O}$ which places it on the trend for sample 15 (fig. 10).

Except for samples 15 and 20, the warmer waters of Warner Valley show an enrichment of ${ }^{18} \mathrm{O}$ generally commensurate with their temperatures. Small discrepancies, such as those between springs 14,16 , and 34 , can probably be readily accounted for by differing mixing proportions of thermal waters with cold waters. Springs 1, 10, 31, and 33, however, with temperatures ranging from $21^{\circ} \mathrm{C}$ to $40^{\circ} \mathrm{C}$, fall relatively close to the meteoric line, suggesting either that the isotopes are not in equilibrium or that the waters have obtained some heat by conduction. The latter possibility is most likely for spring 33, which is located in Coleman Valley in an area of probable high heat flow. Sample 39, obtained at a depth of about 350 feet in heat-flow hole MC2, is a cold water that has probably been enriched in ${ }^{18} \mathrm{O}$, as well as in major ions, by solution of minerals in the valley-fill deposits. The exceptionally low deuterium concentration probably implies that the water originated at high altitude.

Concentrations of the radioactive isotope tritium $\left({ }^{3} \mathrm{H}\right)$ were determined in five samples (table 8 ). Tritium is formed naturally by cosmic radiation in the upper atmosphere, and decays, with a half-life of 12.3 years, to helium-3. Concentrations are reported in tritium units (TU) which equal a ${ }^{3} \mathrm{H} / \mathrm{H}$ ratio of $10^{-18}$, about 3 picocuries per liter. Most tritium now in the hydrosphere is the result of thermonuclear testing in the period 1953 to 1963 . Tritium levels in precipitation in Warner Valley prior to 1953 were probably about $9 \mathrm{TU}$ (T. A. Wyerman, written commun., 1978). According to estimates by Wyerman, levels peaked in 1966 at about $1,000 \mathrm{TU}$ and have declined since then to about $20 \mathrm{TU}$ in 1976.

Samples of tritium collected at one point in time (synoptically), as is the case for the Warner Valley samples, cannot be used to determine exact ages of the waters, but they do provide a basis for estimating relative times of residence in the aquifers. The relatively arge amount of tritium in sample 9, its low temperature $\left(6^{\circ} \mathrm{C}\right)$, and the location of this spring on the valley wall indicate a short residence time, probably on the order of a few years. The other four samples, numbers $12,20,30$, and 41 , have relatively small amounts of tritium which indicate long residence times, on the order of tens of years to hundreds or thousands of years, depending on whether the aquifer is assumed to be recharged by piston flow or complete mixing (Pearson and Truesdell, 1978). The slightly higher level of tritium in sample 12, from the hot well at Crump geyser, suggests that the water is mixed with a larger joportion of young recharge water than are the samples from deeper wells in basaltic rocks or valley-fill deposits (samples 20,30, and 41). These relations are used in a subsequent section of this report in one of the mixing models for the waters of the Crump geyser area. (See section entitled "Temperatures in the Geothermal Reservoir.")

\section{DISTRIBUTIONS OF TEMPERATURE AND HEAT FLOW}

TEMPERATURE OF GROUND WATER

Temperatures were measured in springs and wells at $\$ 2$ sites in the study area. The observed temperatures 
are shown on the location map (pl. 1) and the frequency distribution of temperature is shown in figure 11 for waters having temperatures less than $40^{\circ} \mathrm{C}$. Seven samples of hot water, ranging in temperature from $40^{\circ} \mathrm{C}$ to $93^{\circ} \mathrm{C}$ are omitted. A majority of the waters sampled had temperatures in the range $10^{\circ} \mathrm{C}$ to $15^{\circ} \mathrm{C}$, or about 1 to 6 degrees above the mean annual air temperature at Adel.

The temperature distribution shown in figure 11 is biased by the large number of cold springs sampled in the highlands adjacent to the basin and by the large number of cold wells located near the mouth of Deep Creek. It is clear, however, that most shallow ground water in the basin either has not been heated by deep circulation or has not retained a significant amount of crustal heat. The distribution in figure 11 is highly skewed and would appear even more so if the seven hot-water samples were added to the graph.

The gradational change from cold meteoric waters to geothermal waters in figure 11 provides no basis for distinguishing between these groups. The chemical nature of the water also shows a gradational change (fig. 4) and indicates that many waters having temperatures greater than about $16^{\circ} \mathrm{C}$ have a component derived from hot waters of deep circulation. The temperature of water probably provides an approximate indication of the amount of mixing that has occurred, but, as is shown elsewhere in this report, temperature is not a completely reliable indicator.

The areal pattern of temperature distribution in ground water (pl. 1) does not clearly define areas of geothermal anomalies, but the data are sufficient to show significant differences between areas. In the area north of Hart Lake, the ground waters sampled within the basin boundaries show only a normal increase in temperature with depth and there is no clear evidence of a geothermal resource. Outside the valley walls, Antelope Hot Spring on Hart Mountain is the only known geothermal occurrence. South of Hart Lake, warm waters occur at shallow depths in several areas: at a fault intersection north of Crump Lake, near an intersection of faults on the east side of the valley (Fisher Hot Spring area), between fault intersections on the west side of the Valley (Crump geyser area), and at the base of a tilted fault block at the south end of Warner Valley. Several warm springs and wells are scattered at additional isolated locations in the southern part of Warner Valley, Coleman Valley, and Big Valley.

The factor common to nearly all these occurrences, close proximity to major faults and, in most cases, to fault intersections, is noteworthy. Concealed faults undoubtedly occur at many places beneath the valley floor, and it seems probable that undiscovered geothermal waters occur in association with these faults.

Subsurface resistivity measurements made by audio-magnetotelluric methods show that a large area near Crump geyser is underlain by rocks having anomalously low resistivities (Gregory and Martinez, 1975). Apparent resistivities as low as $2.5 \mathrm{ohm}$ meters occur at apparent depths between 500 and 1,000 feet and resistivities of $4 \mathrm{ohm}$ meters or less were measured beneath an area covering about a square mile. These data are probably best explained by the assumption that a reservoir of hot water having high electrical

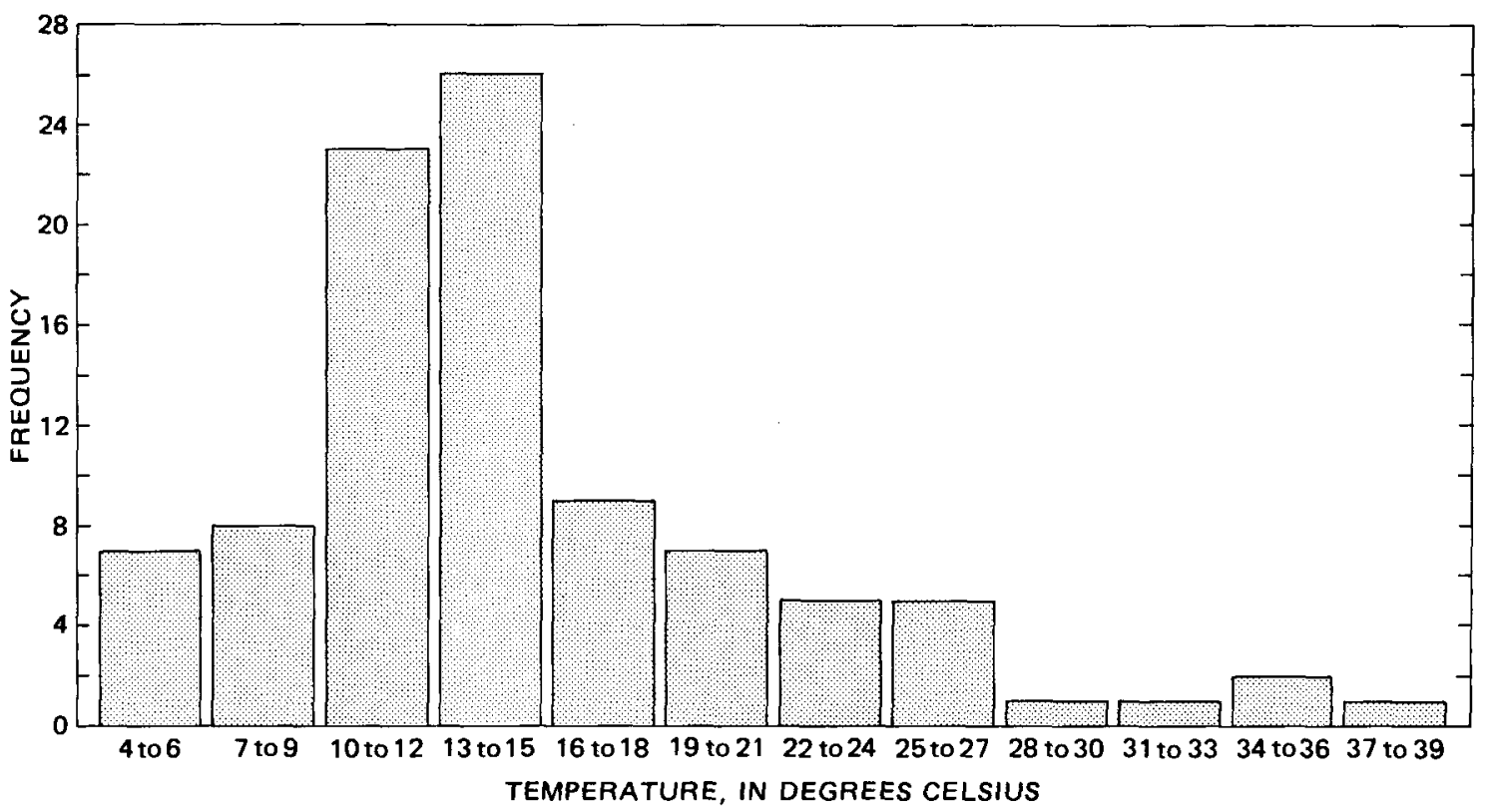

FIGURE 11.-Frequency of temperatures $\left(<40^{\circ} \mathrm{C}\right)$ measured in springs and wells. 
conductivity occurs at the indicated depths.

Resistivity measurements are not available in the same detail for other sites, and the areal extent of shallow warm waters elsewhere in the valley cannot be estimated by this method. Temperature profiles and heat-flow data, described below, suggest that at least one other extensive area of the basin contains thermal waters.

\section{HEAT FLOW}

Temperature profiles were obtained in six unused water wells and three test holes (table 3 and figs. 12 and 13). Locations of these wells and test holes are shown in plate 1 . The three test holes, MC1, MC2, and OK1, were completed as heat-flow holes in 1976 . Ten additional heat-flow holes were drilled in 1979 by the Geological Survey. Temperature and heat-flow measurements obtained in the 10 holes by means of an insitu probe (Sass and others, 1979) are available only in preliminary form. Data and interpretations from these sites will be released in the near future.

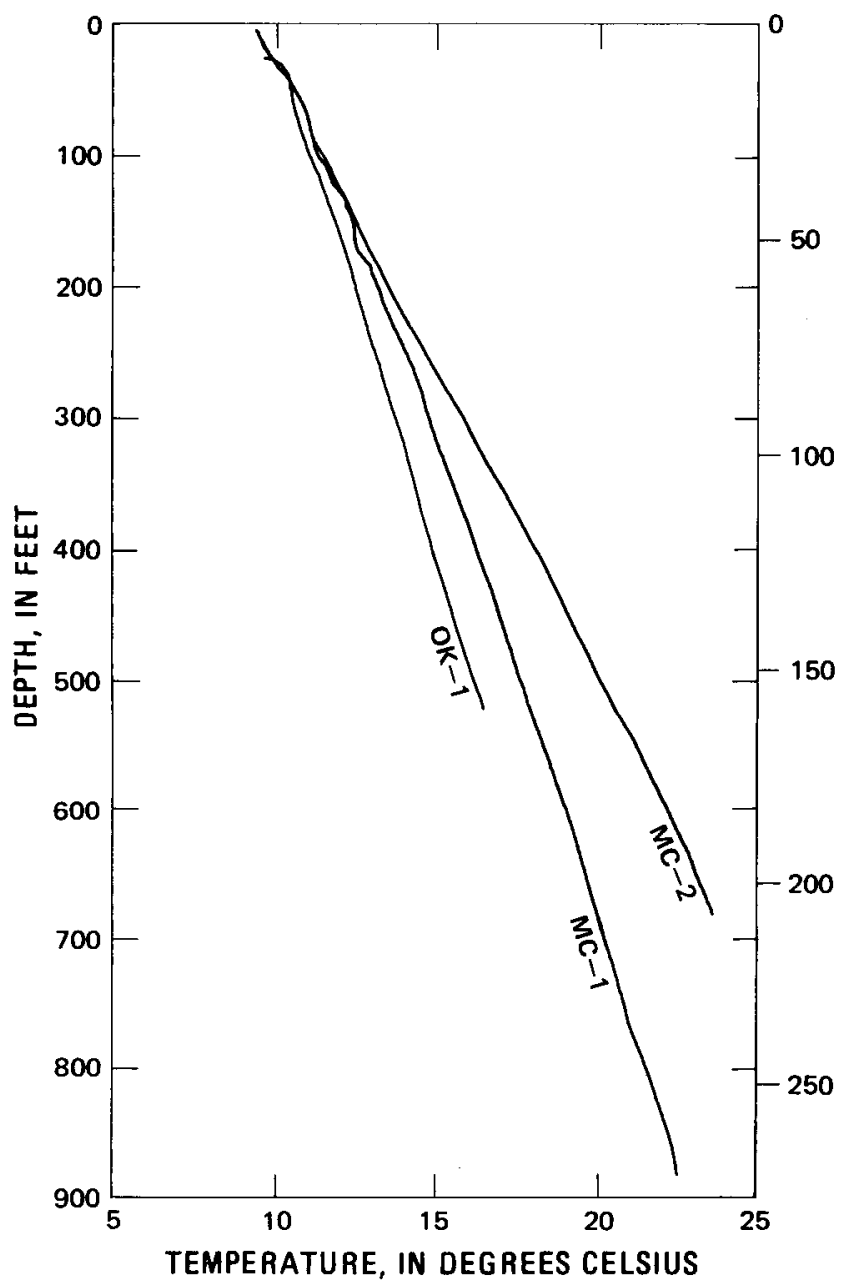

Figure 12.-Profiles of temperature measured in heat-flow holes.
Preliminary interpretation of the thermal data indicates that, in the areas north of Hart Lake and in the center of Warner Valley south of Adel, heat flow is about 75 milliwatts per square meter $\left(\mathrm{mW} \mathrm{m}^{-2}\right)$, which is in the lower part of the normal range for this region of the Basin and Range province (Charles Mase, written commun., 1980). On the basis of temperature profiles from holes $\mathrm{MC1}$ and $\mathrm{OK} 1$, the average normal thermal gradient in the valley-fill deposits may be in the range $40^{\circ} \mathrm{C} \mathrm{km}^{-1}$ to $45^{\circ} \mathrm{C} \mathrm{km}^{-1}$. Thus, if temperatures near land surface are about $10^{\circ} \mathrm{C}$, temperatures in parts of the valley unaffected by recharge or thermal convection should be at least $16^{\circ} \mathrm{C}$ at 500 -foot depths and at least $22^{\circ} \mathrm{C}$ at 1,000 feet. The minimum depth of circulation required to attain temperatures of $20^{\circ} \mathrm{C}$ or more would be 730 feet.

Thermal gradients and heat flows are apparently higher than normal at several of the 10 recent test sites. These sites include a location 1 mile west of Hart Lake, another about 5 miles north of Crump geyser, and three sites near Fisher Hot Spring. Thermal gradients at these sites ranged from $113^{\circ} \mathrm{C} \mathrm{km}^{-1}$ to $600^{\circ} \mathrm{C}$ $\mathrm{km}^{-1}$, and apparent heat flows ranged from 125 to 689

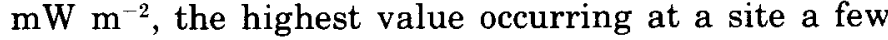
hundred feet from Fisher Hot Spring (Charles Mase, written commun., 1980). No measurements were obtained at the extreme south end of the valley near the site of spring 34 , but temperatures reportedly measured in the tilted fault block at this location by a private exploration company suggest that heat flow may be above normal.

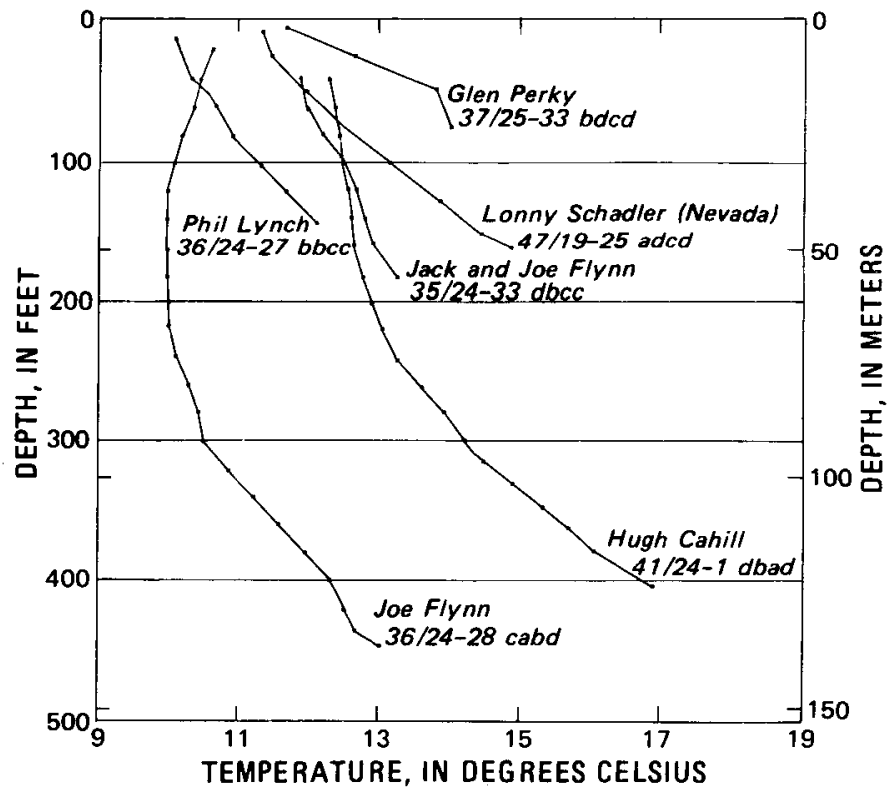

FIGURE 13.-Profiles of temperature in water wells. 
The high thermal gradients and heat flows measured in the areas described above occur as the result of circulation of hot water that is believed to rise in the nearby faults and spread laterally through shallow basaltic rocks and the valley-fill deposits. The extent and depth of the spreading zone in the Crump geyser areas were estimated, on the basis of AMT measurements, to be at least $1 \mathrm{mi}^{2}$ and 1,000 feet, respectively. The heat-flow data obtained near Fisher Hot Spring suggest a zone of comparable size at this location. Elsewhere in the valley, the volumes of shallow hot water are unknown.

The subsurface temperature distribution in the Crump geyser area was investigated further by means of measurements obtained in holes driven or augered to depths of 2 meters. The area covered by these small-diameter holes is shown in figure 14, where generalized lines of equal temperature have been drawn on the data obtained at 2-meter depths. Temperatures obtained at shallower depths showed a large amount of scatter resulting from surface effects and insolation, but the measurements at 2 meters were fairly consistent. Many of the holes did not reach the full depth of 2 meters, and for these holes, the temperatures given in figure 14 were extrapolated from shallower measurements.

The number of data points shown in figure 14 is insufficient to define the temperature distribution fully, but the general characteristics of the shallow thermal anomaly in the vicinity of Crump geyser are probably indicated fairly well. The thermal disturbance resulting from the geologically recent imposition of the two hot wells (wells 12 and 13) appears as a minor perturbation in the temperature field. The cause is probably the spreading of hot water that erupts and leaks from the wells. A much larger anomaly appears in the area of siliceous-sinter mounds and hot springs that occupies about $4 \frac{1 / 2}{2}$ acres to the east of the wells. The spread of hot water from these sources, and possibly from others that may be concealed, raises temperatures to more than $60^{\circ} \mathrm{C}$ over a large area.

The mounds of siliceous sinter that dot the area stand 4 or 5 feet above the surrounding terrane. Springs and seeps occur both at the edges of these mounds and in isolated locations. Strata of sinter were encountered in the temperature holes at depths of about 3 feet at several places where no springs exist at present. The mounds and strata suggest that hydrothermal activity was formerly greater than at present and that the hydraulic heads in the springs were higher than existing heads.

The shallow thermal anomalies in the Crump geyser area appear to be caused by the lateral spread of hot water from seeps, springs, and wells. The large thermal anomaly inferred from geophysical measurements is believed to be caused by spreading, at greater depths, of hot water from two or more intersecting faults. Two faults have been mapped as striking N. $48^{\circ}$ W. and intersecting the north-trending boundary fault at points located a few hundred yards north and south of the geyser area.

A large area of low heat flow and low thermal gradients occurs in and adjacent to the former delta of Deep Creek near Adel (Charles Mase, written commun., 1980). In this area, ground-water inflow from the canyon of Deep Creek, a probable fault zone, lowers temperatures of ground water in the adjacent valleyfill deposits. Reports of temperatures encountered in the San Juan Oil Co. test well, located 1 mile east of Adel, indicate that this cold-water inflow persists to great depths in the Tertiary rocks beneath the valleyfill deposits.

Profiles of temperature measured in six water wells in Warner Valley (fig. 13) show good agreement with data from the heat-flow holes. The correlation is surprising because thermal gradients derived from measurements in water wells are often unreliable owing to convection in the well or outside the casing. Several of the Warner Valley profiles show large effects of convective flow, most notably in well 36/24-28cabd (Flynn), where the thermal gradient is reversed in the upper 150 feet of the well. However, the relatively uniform gradients observed in the lower sections of most profiles generally confirm the data from the heat-flow holes and suggest that thermal gradients are low at the north end of the valley and are higher than normal at the south end and in Coleman Valley. Gradients observed in the water wells range from $36^{\circ} \mathrm{C} \mathrm{km}^{-1}$ to $58^{\circ} \mathrm{C}$ $\mathrm{km}^{-1}$ in three wells north of Hart Lake, and from $82^{\circ} \mathrm{C}$ $\mathrm{km}^{-1}$ to $86^{\circ} \mathrm{C} \mathrm{km}^{-1}$ in two wells in Coleman Valley. A sixth well, 37/25-33bdcd, located about $1 \frac{1 / 2}{2}$ miles north of Fisher Hot Spring, had an extremely high gradient in the upper 50 feet which is probably evidence of the convective flow of hot water at shallow depths in this area.

\section{TEMPERATURES IN THE GEOTHERMAL} RESERVOIR: ESTIMATES FROM MIXING MODELS AND CHEMICAL GEOTHERMOMETERS

Temperatures of equilibration were calculated for all waters having surface temperatures of $20^{\circ} \mathrm{C}$ or more (table 9). The geothermometers used for these calculations are the silica geothermometer of Fournier and Rowe (1966) and Fournier (1973) and the Na-K-Ca geothermometer of Fournier and Truesdell (1973). The silica geothermometer based on quartz equilibrium is assumed to apply if the apparent equilibration temperature is greater than $110^{\circ} \mathrm{C}$. Below $110^{\circ} \mathrm{C}$, equilibration is assumed to occur with chalcedony. This distinction is made arbitrarily for the Warner Valley waters on the basis of data from Iceland, where chalcedony 


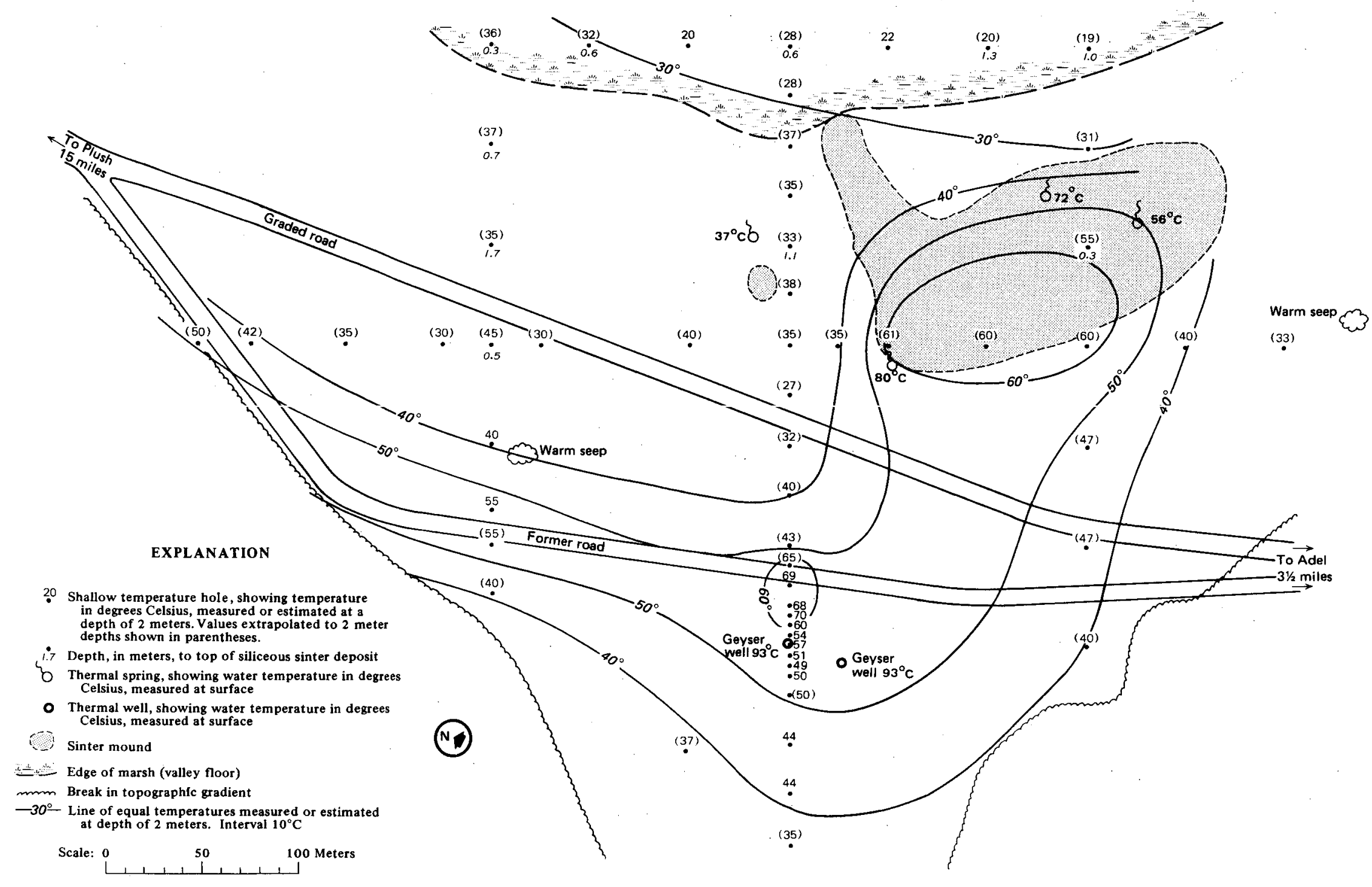


equilibration was established at temperatures less than $110^{\circ} \mathrm{C}$ for virtually all waters occurring in basaltic rocks (Arnórsson, 1975).

The graph in figure 15 shows that the agreement between the silica and $\mathrm{Na}-\mathrm{K}-\mathrm{Ca}$ geothermometers ranges from poor to excellent, with generally good agreement occurring in waters having temperatures of $40^{\circ} \mathrm{C}$ or more. Indicated reservoir temperatures are generally high for waters having moderate to high measured temperature, and for these waters the $\mathrm{Na}-\mathrm{K}-\mathrm{Ca}$ geothermometer temperatures are, with only one exception, lower than the quartz geothermometer temperatures. The lower temperatures indicated by the Na-K-Ca geothermometer are consistent with changes in the $\mathrm{Na} / \mathrm{K}$ and $\mathrm{Ca} / \mathrm{Na}$ ratios that would be expected as the result of water-rock reactions during the ascent of thermal waters from a deep reservoir (Fournier and Truesdell, 1973).

Equilibration temperatures shown in figure 15 represent the authors' selection of the most probable geothermometer temperature indicated for each sample. The quartz-conductive temperature was preferred over the adiabatic-cooling temperature for all silicabased temperatures greater than $110^{\circ} \mathrm{C}$. The rejection of the adiabatic-cooling model is based on the lack of evidence of steam separation in the subsurface and the high probability that the thermal waters have cooled conductively during their ascent. The conductive cooling model is discussed below in the section entitled "Conceptual Models of the Geothermal System."

The Na-K-Ca geothermometer temperature selected for the lower-temperature waters in figure 15 includes a correction for the concentration of magnesium in the sample. According to Fournier and Potter (1978), this empirical correction should be applied to the Na-K-Ca geothermometer whenever a thermal water has equilibrated in the presence of sufficient magnesium to affect the $\mathrm{Na} / \mathrm{K}$ and $\mathrm{Ca} / \mathrm{Na}$ ratios significantly. The correction is based largely on the value of $R$, the percent $\mathrm{Mg} /(\mathrm{Mg}+\mathrm{Ca}+\mathrm{K})$ in equivalents (table 9 ), and is used when $\mathrm{R}$ has values less than 50 and the $\mathrm{Na}-\mathrm{K}-\mathrm{Ca}$ geothermometer temperature is not less than $70^{\circ} \mathrm{C}$. The magnitude of the correction is a function of both the $\mathrm{R}$ value and the $\mathrm{Na}-\mathrm{K}-\mathrm{Ca}$ geothermometer temperature. Large values of $\mathrm{R}$ and estimated temperature require large temperature corrections. For example, an $R$ value of 50 and an estimated temperature of $200^{\circ} \mathrm{C}$ requires a negative correction of about $185^{\circ} \mathrm{C}$. An $R$ value of 2 would require no correction at temperatures less than about $195^{\circ} \mathrm{C}$.

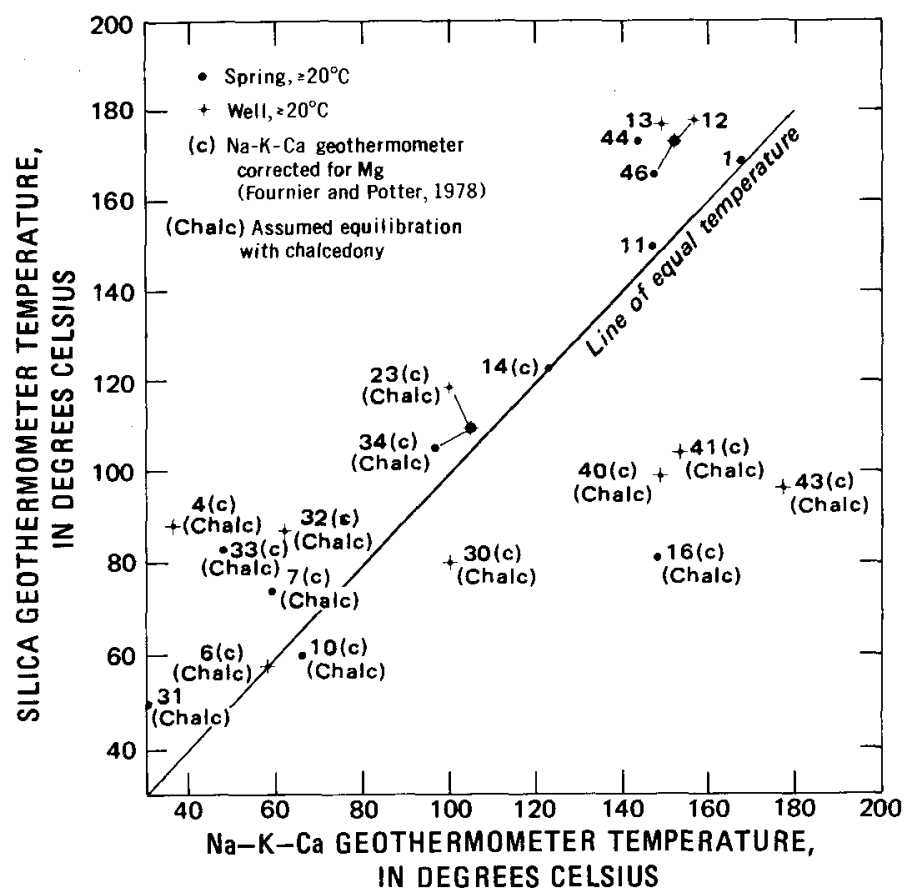

Figure 15. - Gr, h showing correlation between temperatures estimated by the silica and Na-K-Ca geothermometers. 
Magnesium concentrations are low and values of $R$ are correspondingly low for well 12 and springs 44 and 46 in the Crump geyser area; the $\mathrm{Na}-\mathrm{K}-\mathrm{Ca}$ geothermometer consequently needs little or no correction for these waters. Other waters, such as springs 1,11 , and 14 , have larger $R$ values, but are highly mixed waters in which the magnesium concentrations may have been acquired during or after mixing. No correction is used for springs 1 and 11, but the indicated temperature for spring 14 has been corrected in order to bring the $\mathrm{Na}-\mathrm{K}-\mathrm{Ca}$ temperature into agreement with the quartz equilibration temperature of $123^{\circ} \mathrm{C}$. This temperature fits well in the mixing models discussed below.

In the remainder of this section, a detailed examination is made of the chemical relations in 10 of the hotter waters in order to justify the conclusions regarding the geothermal reservoir. The final conclusions depend largely on the relations between waters from the Crump geyser area and those from the Fisher Hot Spring area. Other thermal waters are fitted into the conceptual model with varying degrees of confidence.

\section{CRUMP GEYSER AREA}

Samples 12,13 , and 44 were obtained in two boiling wells and a spring, respectively, which are located near the western boundary fault about 3 miles north of Adel. Measured surface temperatures are, respectively, $93^{\circ} \mathrm{C}, 93^{\circ} \mathrm{C}$, and $78^{\circ} \mathrm{C}$. The temperature at a clepth of 660 feet in well 13 is reported to be $127^{\circ} \mathrm{C}$ and the maximum temperature in well 12 was $124^{\circ} \mathrm{C}$. Temperatures in the spring (44) have previously been observed to be somewhat higher than the temperature reported here. Chemical analyses of major constituents (table 6) show that the three waters are virtually identical.

The quartz conductive geothermometer indicates that the temperature of equilibration is at least $173^{\circ} \mathrm{C}$ for the three waters, whereas the Na-K-Ca geothermometer indicates a temperature close to $150^{\circ} \mathrm{C}$. If the quartz conductive geothermometer is accepted as the rnore reliable of the three silica geothermometers, and if the chloride concentrations and mixing models (discussed below) are accepted as probably correct, the

TABLE 9. Calculated temperatures of equilibration for waters having surface temperatures of $20^{\circ} \mathrm{C}$ or more

\begin{tabular}{|c|c|c|c|c|c|c|c|c|c|}
\hline \multirow{3}{*}{$\begin{array}{l}\text { Sequence } \\
\text { No. }\end{array}$} & \multirow{3}{*}{ Owner or name } & \multirow{3}{*}{$\begin{array}{c}\text { Measured } \\
\text { temperature } \\
\left({ }^{\circ} \mathrm{C}\right)\end{array}$} & \multicolumn{7}{|c|}{ Calculated reservoir temperature $\left({ }^{\circ} \mathrm{C}\right)$} \\
\hline & & & \multirow{2}{*}{$\begin{array}{c}\text { Qtz. } \\
\text { (adiab.)1 }\end{array}$} & \multirow{2}{*}{$\begin{array}{c}\text { Qtz. } \\
\text { (cond.) }\end{array}$} & \multirow{2}{*}{$\begin{array}{l}\text { Chalced. } \\
\text { (cond.) }\end{array}$} & \multicolumn{2}{|c|}{$\mathrm{Na} / \mathrm{K}+\beta \sqrt{ } \mathrm{Ca} / \mathrm{Na}^{2}$} & \multirow[b]{2}{*}{$\mathrm{R}^{4}$} & \multirow[b]{2}{*}{$\delta^{18} \mathrm{O}\left(\mathrm{SO}_{4}\right)^{5}$} \\
\hline & & & & & & . & $\underset{\text { corrected }^{3}}{\mathrm{Mg}}$ & & \\
\hline 12 & Charles Crump & 93 & 163 & 173 & 151 & 152 & 152 & 0.9 & 208 \\
\hline $1 \overline{3}$ & Charles Crump & 93 & 165 & 177 & 155 & 149 & 142 & 6.1 & \\
\hline 44 & MC Ranch (spg) & 78 & 163 & 173 & 151 & 144 & 144 & 1.5 & 202 \\
\hline 14 & Fisher Hot Spring & 68 & 121 & 123 & 95 & 169 & 123 & 11.7 & 139 \\
\hline 34 & Hugh Cahill (spg) & 66 & 132 & 136 & 109 & 125 & 105 & $\begin{array}{l}11.1 \\
13.7\end{array}$ & 179 \\
\hline 46 & Henry O'Keefe (spg) & .58 & 163 & 173 & 151 & 152 & 150 & 4.3 & 219 \\
\hline \multirow[t]{2}{*}{1} & US Fish and Wildlife & & & & & & & & \\
\hline & (Antelope Hot Spring) & 40 & 159 & 169 & 146 & 168 & 87 & 19.8 & 125 \\
\hline 11 & Charles Crump (spg) & 40 & 144 & 150 & 125 & 147 & 112 & 12.8 & 200 \\
\hline 16 & US BLM (spg) & 38 & 109 & 110 & 81 & 158 & 148 & 5.8 & $-\ldots$ \\
\hline 23 & Lonny Schadler & 33 & 131 & 136 & 109 & 253 & 105 & 21.2 & --- \\
\hline 10 & John Lane (spg) & 29 & 93 & 91 & 60 & 777 & ${ }^{7} 66$ & 31.6 & 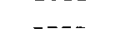 \\
\hline 7 & Dixon (spg) & 27 & 104 & 104 & 74 & 193 & 59 & 29.2 & --- \\
\hline 43 & Lonny Schadler & 27 & 122 & 124 & 96 & 230 & 177 & 7.8 & ---- \\
\hline 30 & US BLM (Sandy Well) & 25.5 & 109 & 109 & 80 & 233 & 100 & 19.9 & ---- \\
\hline 31 & Don Robinson (spg) & 23 & 84 & 81 & 50 & 729 & $(8)$ & 12.6 & --- \\
\hline 41 & $\mathrm{MC}-2$ & 22.5 & 128 & 132 & 104 & 191 & 153 & 8.0 & $-\ldots$ \\
\hline 32 & James Dyke & 21 & 114 & $11 \overline{5}$ & 87 & 177 & 62 & 27.6 & --- \\
\hline $3 \overline{3}$ & Foskett Spring & 21 & 112 & 112 & 83 & 792 & 48 & 37.9 & $-\ldots+$ \\
\hline 40 & $\mathrm{MC}-2$ & 21 & 124 & 127 & 99 & 189 & 149 & 8.6 & $-n$ \\
\hline 4 & Phillip Lynch & 20.5 & 116 & 117 & 88 & 161 & 36 & 37.8 & ---- \\
\hline 6 & Glen Perky & 20 & 91 & 88 & 58 & 758 & $(8)$ & 37.6 & $\ldots$ \\
\hline
\end{tabular}

iFournier (1977)

${ }^{2} \beta=1 / 3$ except where noted (Fournier and Truesdell, 1974).

${ }^{3}$ Fournier and Potter (1978).

${ }^{4} \mathrm{R}=\frac{\mathrm{Mg}}{\mathrm{Mg}+\mathrm{Ca}+\mathrm{K}} \times 100$; units of concentration are equivalents (Fournier and Potter, 1978).

${ }^{5} \mathrm{McKenzie}$ and Truesdell (1977).

${ }^{6}$ Nehring and others (1979).

${ }_{7} \beta=4 / 3$ (Fournier and Truesdell, 1974).
${ }^{8}$ UFormula not applicable: - estimated Na-K-Ca temperature less than $70^{\circ} \mathrm{C}$ (Fournier and Potter, 1978), 
lower temperatures indicated by the Na-K-Ca geothermometer can be explained as the result of water-rock reactions that occur as the waters ascend from the reservoir and cool. The likelihood of this explanation is supported by data from two of the samples, well 12 and spring 44 , in which a difference of $8^{\circ} \mathrm{C}$ between the two $\mathrm{Na}-\mathrm{K}-\mathrm{Ca}$ temperatures results from minor chemical changes that occur in the spring as the water rises and cools $15^{\circ} \mathrm{C}$.

The fairly high reservoir temperature indicated by the silica geothermometer is supported by the observed shift in the $\delta^{18} \mathrm{O}$ ratio (fig. 7 ) of about 2 per mil relative to values in cold regional waters. The amount of increase suggests equilibration at fairly high temperatures and is compatible with the estimated temperature of $175^{\circ} \mathrm{C}$.

High rates of chloride to calcium, magnesium, sodium, sulfate, and total carbonate species are also compatible with relatively long residence times at high temperatures (table 7). The ratio of sodium to potassium is fairly large, however, indicating that reservoir temperatures are probably not extremely high (White, 1970).

The close similarity in ionic concentrations and ratios among the three waters clearly points toward common origins and subsurface movements. The lower temperature of the spring water is probably explained by the additional conductive cooling of this water.

If these waters are assumed to rise and spread from the adjacent boundary fault, it might be expected that some mixing occurs with local ground water. The tritium concentration in sample 12 (table 8 ) indicates that such mixing does occur. The amount of mixing can be estimated by assuming, on the basis of cold-water sample 9 in table 8 , that the tritium concentration of the recharge water is about 90 tritium units (TU). If the tritium concentration in the geothermal reservoir is assumed to be zero, the fraction of cold water in sample 12 is calculated to be 0.06 . The uncertainty in this fraction is large because of uncertainty as to the exact nature of the cold recharge water. The results of other mixing models discussed below show, however, that the fraction is probably close to the value indicated by the tritium model.

Possible modes of origin for the thermal waters of the Crump geyser area are suggested by the silicaenthalpy relations shown in figure 16 (Fournier, 1977). The three simplest of the possible modes are described below as they apply to sample 12, the water least affected by near-surface boiling or conductive cooling.

The extension of the mixing line through sample 12 in figure 16 intersects the lowest possible enthalpy of steam separation for the altitude of Warner Valley at 96 calories per gram ( $\mathrm{cal} \mathrm{g}^{-1}$ ). A vertical line from this point (M 2) intersects the curve for maximum steam loss due to adiabatic cooling (Fournier, 1977) and then may be directed horizontally to intersect the curve for quartz equilibration at M1 (enthalpy $=166 \mathrm{cal} \mathrm{g}^{-1}$ ). Point M1 indicates the minimum enthalpy and silica concentration of a possible reservoir water supplying water M2, which is assumed to mix with a typical cold recharge water (point $A$ ) to form the water of sample 12. The horizontal boiling path from point M1 to the maximum steam-loss curve represents the increase in quartz concentration due to boiling. The vertical path from the maximum steam-loss curve to point M2 represents the energy loss (cooling) due to boiling. The enthalpy estimated for the reservoir is not greatly sensitive to the choice of the steam-separation point (M2).

An alternative mode of origin for sample 12 is one in which the water cools conductively from the enthalpy indicated by the quartz conductive geothermometer (near point $P$ in the diagram) and then mixes from point M2. A third possible origin would produce the shallow thermal water by direct mixing of cold water with water from a reservoir having an enthalpy of about $245 \mathrm{cal} \mathrm{g}^{-1}$ (point M3).

The waters of well 13 and spring 44 are believed to originate in the same way as the water of well 12 . The displacement of sample 13 relative to sample 12 is readily explained by the surface boiling that is observed in the large-diameter well of sample 13 . The position of sample 44 in the diagram appears to be the result of additional conductive cooling as the hot water flows to the spring at shallow depths.

The third hypothesis, mixing from a high-enthalpy reservoir, is believed to be unlikely on the basis of indications from mixing models. The fraction of cold water calculated from the tritium mixing model is 0.06 , whereas the fraction indicated by mixing from a high-enthalpy reservoir in figure 16 is 0.66 . A coldwater fraction of 60 percent or more would probably introduce a significant concentration of magnesium into the mixture, whereas observed concentrations are less than $1 \mathrm{mg} \mathrm{L}^{-1}$, thus lending weight to the evidence favoring only minor amounts of mixing. Either of the first two models, adiabatic cooling with steam separation or conductive cooling from near point $P$ is possible on the basis of the silica-enthalpy relations, and each postulates a reservoir temperature of at least $165^{\circ} \mathrm{C}$. However, the lack of any evidence of steam separation or of vapor transport and the high probability of conductive cooling at the observed flow rates favors the conductive-cooling model.

A second approach to mixing models utilizes the chloride-enthalpy relation and assumes that most chloride in thermal waters is released by water-rock reactions at high temperatures in the geothermal res- 


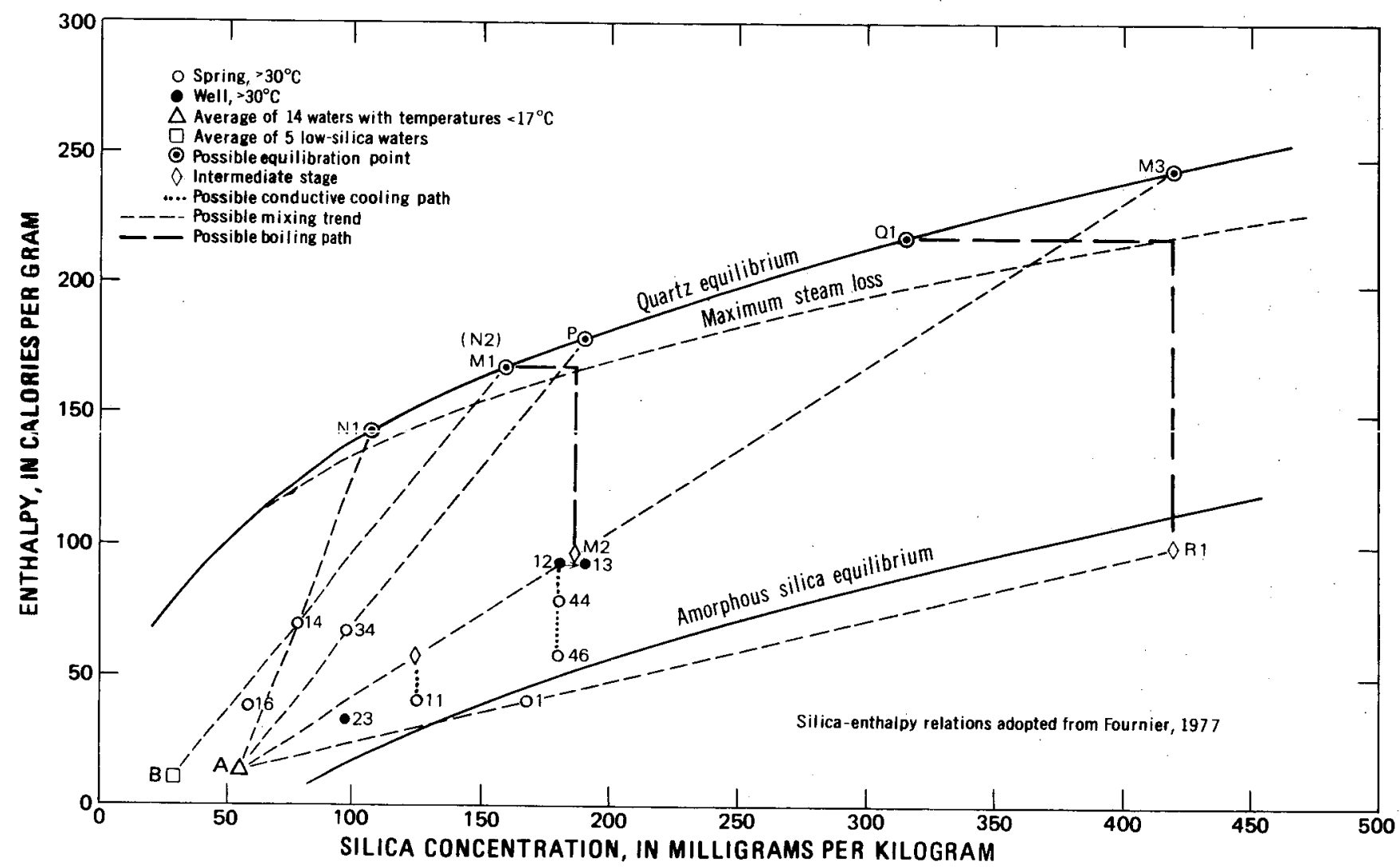

FIGURE 16.-Graph of silica concentration versus enthalpy in waters having surface temperatures $>30^{\circ} \mathrm{C}$. 
ervoir (Fournier and others, 1979; Truesdell and Fournier, 1976; Fournier, 1977). The diagram of figure 17 shows possible equilibration points, conductive cooling paths, and mixing paths for the 10 samples having temperatures greater than $30^{\circ} \mathrm{C}$.

In figure 17, the high-chloride, low-enthalpy waters of samples 12,13 , and 44 are shown in relation to two possible points of origin, M1 and M4. Point M1 corresponds closely to the similar point in the silica-enthalpy diagram from which boiling might occur. Point M4 is an equilibration point determined by the silica geothermometer from which conductive cooling could occur.

The line connecting points M1 and M2 in figure 17 represents an adiabatic cooling curve constructed by extending a line from M2, the point of steam separation, to a point of zero chloride concentration and an enthalpy of $639 \mathrm{cal} \mathrm{g}^{-1}$ representing the composition of pure steam (Truesdell and Fournier, 1976).

The mixing fractions of cold water calculated for well 12 from the chloride-enthalpy and silica-enthalpy graphs are identical $(0.05)$, and are close to the value

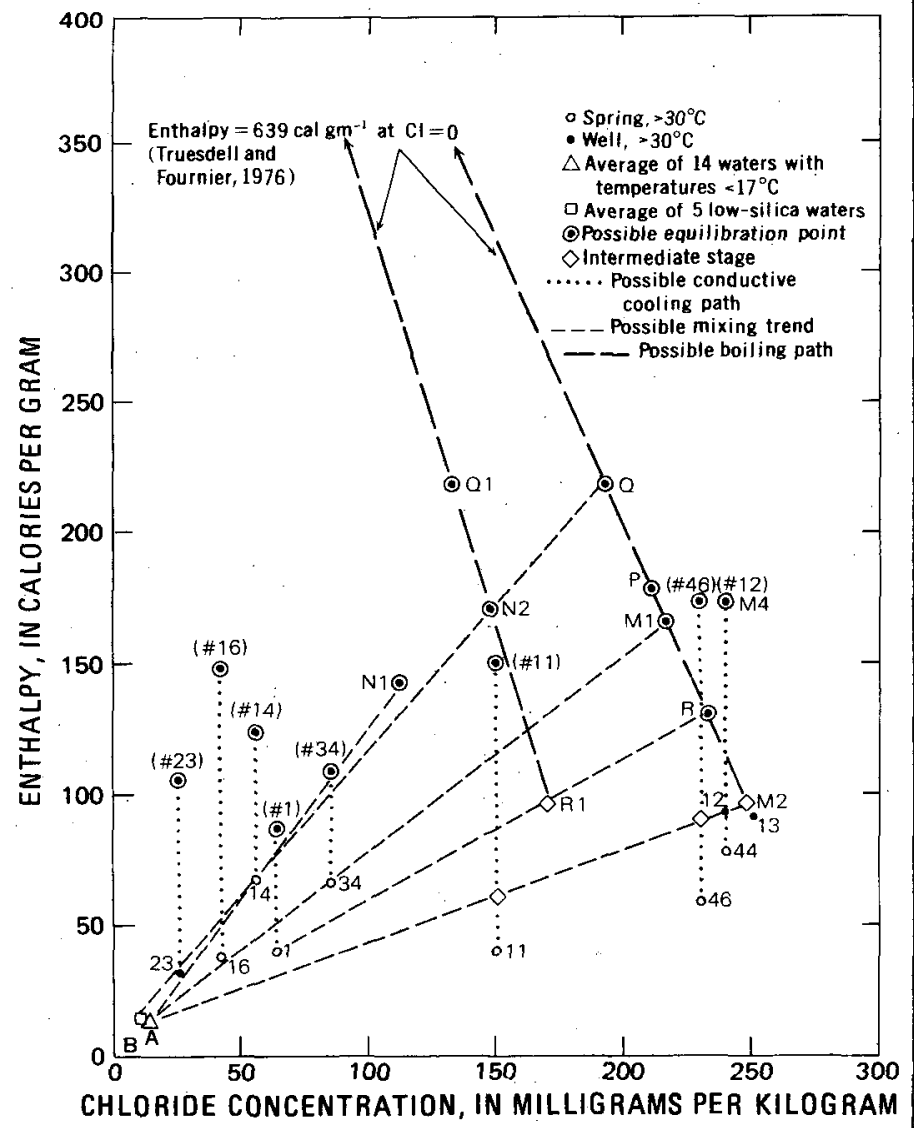

Figure 17.-Graph of chloride concentration versus enthalpy in waters having surface temperatures $>30^{\circ} \mathrm{C}$. obtained from the tritium mixing model (0.06). Although the coincidence inspires some confidence in the mixing models and in the probability of an origin in a reservoir at about $170^{\circ} \mathrm{C}$, the data do not permit a clear choice between the alternatives of conductive or adiabatic cooling. These alternatives are discussed further at the end of this section of the report.

Corroborative evidence for the mixing trend between M2 and cold water is provided by the data from spring 11. This spring, with a temperature of $40^{\circ} \mathrm{C}$ and a flow of about 5 gallons per minute ( $\mathrm{gal} \mathrm{min}^{-1}$ ), is located along the west boundary fault about a mile north of well 12. The water has a chemical composition similar to those of the Crump geyser waters (fig, 4), but roughly half the dissolved-solids concentration.

It seems reasonable to assume that the water in spring 11 has cooled conductively, perhaps $15^{\circ} \mathrm{C}$ or $20^{\circ} \mathrm{C}$, as spring 44 is believed to do. This assumption places spring 11 on the mixing trend for well 12 in both the chloride and silica diagrams. On the basis of the mixing line from point $\mathrm{M} 2$, cold-water fractions in spring 11 are calculated to be $0.48,0.44$, and 0.52 , respectively, for the constituents silica, chloride, and dissolved solids. The dissolved solids concentration at M2 was estimated from ratios of silica and chloride to dissolved solids in sample 12 . Thus, the mixing model shows excellent agreement for these constituents and indicates that the thermal component of spring 11 could have originated in water represented by point M2.

There remains the possibility that the water of spring 11 has attained its present state entirely by conductive cooling from its indicated quartz conductive geothermometer temperature of about $150^{\circ} \mathrm{C}$. This possibility cannot be entirely ruled out, but the small concentration of dissolved solids $\left(662 \mathrm{mg} \mathrm{L}^{-1}\right)$ in the water is incompatible with equilibration at this temperature and indicates that mixing has occurred. Ratios of major ions in spring 11 also support the concept of lowtemperature mixing. Ratios of calcium, magnesium, and bicarbonate to chloride and sodium are increased by the mixing, while ratios of sodium to potassium, chloride to sodium, and chloride to sulfate remain similar to those in the higher temperature water. The mixing model explains these observations better than the conductive-cooling hypothesis.

A third spring which is included with the Crump geyser waters on the basis of its chemical composition is spring 46 , located about one mile south of Crump geyser and about 0.6 miles east of the boundary fault. This spring, with a temperature of $58^{\circ} \mathrm{C}$ and a flow rate of about 3 gal $\mathrm{min}^{-1}$, issues at the end of a peninsulalike sinter terrace about 0.6 miles long extending southeast from the fault zone. At least six additional 
springs and seeps having low flows and temperatures ranging from $35^{\circ} \mathrm{C}$ to $49^{\circ} \mathrm{C}$ also issue from the terrace.

The chemical composition of spring 46 is similar in all important respects to the compositions of wells 12 and 13 and spring 44 ; the silica concentration is identical to that of well 12 and the chloride concentration is only slightly lower than that of well $12\left(230 \mathrm{mg} \mathrm{L}^{-1}\right.$ versus $240 \mathrm{mg} \mathrm{L}^{-1}$ ) (table 6).

The virtual coincidence of ionic concentrations in the Crump geyser water and spring 46 compels the belief that the two waters originate in the same reservoir and probably ascend in the same fault. It is significant, therefore, that the water of spring 46 undergoes little change in ionic concentrations (with the possible exception of an increase in boron) as it flows 0.6 miles from the fault zone to its outlet while cooling about $35^{\circ} \mathrm{C}$. The lack of water-rock interaction during this passage implies that the water moves in a conduit that is probably armored with silica and that has remained open during the time required to precipitate the large amount of silica laid down in building the sinter terrace. Further important implications are that the hot waters of the Crump geyser area can presumably move upward from the reservoir in similar armored conduits while changing little in composition as they cool conductively. The indirect evidence afforded by spring 46 thus tends to increase confidence in the belief that the Crump geyser waters closely approximate the chemical composition of the geothermal reservoir.

Waters from the two wells and three springs in the Crump geyser area appear to define a lower limiting trend on the silica-enthalpy and chloride-enthalpy diagrams (figs. 16 and 17). Spring 1, which falls below this trend on the silica graph, is an isolated spring at high altitude whose relation to thermal waters in Warner Valley is unclear. This spring is discussed below. All other thermal waters fall on or above the trend established by 12,13 , and 44 if about $20^{\circ} \mathrm{C}$ of conductive cooling is accepted for spring 11 , and $30^{\circ} \mathrm{C}$ or more of cooling has occurred in spring 46 .

\section{FISHER HOT SPRING AREA}

An upper limiting trend in both the silica and chloride diagrams is determined by the mixing lines through spring 14, Fisher Hot Spring. This spring has a surface temperature of $68^{\circ} \mathrm{C}$ and an estimated flow of 15-20 gal $\mathrm{min}^{-1}$. The calculated temperature of equilibration is $123^{\circ} \mathrm{C}$ for both the quartz conductive and the magnesium-corrected $\mathrm{Na}-\mathrm{K}-\mathrm{Ca}$ geothermometers.

The concentration of dissolved solids ( $360 \mathrm{mg} \mathrm{L}^{-1}$ ) and the position of this water on the chloride and silica diagrams (figs. 16 and 17) and the trilinear diagram (fig. 4) suggest that this is a mixed water. Ratios of major ionic constituents (table 7) are similar to those in spring 11 and show changes relative to the hotter waters that are consistent with low-temperature mixing. For these reasons, the line showing a direct conductive cooling path in figure 17 is not favored as an explanation for the origin of this water.

If the water of Fisher Hot Spring is assumed to be highly mixed, as its chemical composition suggests, several possible mixing relations can be postulated from figures 16 and 17 . In figure 16 , thermal water at $\mathrm{N} 1$, having an equilibration temperature of $143^{\circ} \mathrm{C}$ may mix with cold water represented by point $\mathrm{A}$. The fraction of cold water calculated for this mixture is 0.58 , and is the same for the corresponding mixture on the chloride-enthalpy graph. The temperature of equilitration indicated by point $\mathrm{N} 1$ is $20^{\circ} \mathrm{C}$ higher than the temperature estimated by the quartz and $\mathrm{Mg}$-corrected $\mathrm{Na}-\mathrm{K}-\mathrm{Ca}$ geothermometers but is close to the temperature of $139^{\circ} \mathrm{C}$ indicated by the sulfate-oxygen geotherrnometers. The latter geothermometer may not be relia.ble if the water is mixed, however, and lowtemperature sulfate is introduced in the mixture (Nehring and Mariner, 1979).

A second possible mixing path utilizes average valtes of silica in five low-silica cool waters (point $B$, figs. 16 and 17). The five waters $(5,6,36,37$, and 42$)$ include four high-altitude cold springs on the eastern fault blocks and a well located about 3 miles north of Fisher Hot Spring. These waters differ somewhat from other cool waters in the area, and they could represent a mixing water that occurs on the east side of the valley. The equilibration temperature for quartz at which this trend ends in figure 16 (point N2) coincides with the uncorrected $\mathrm{Na}-\mathrm{K}-\mathrm{Ca}$ temperature (about $168^{\circ} \mathrm{C}$ ).

Other explanations for the origin of spring 14 are possible, including various combinations of conductive cooling and mixing from high- or low-temperature reservoirs. One alternative hypothesis, given below, seems more probable than others when all the available evidence is considered.

Abnormally high thermal gradients and heat flow in the area near Fisher Hot Spring have been described in the section of the report entitled "Distributions of Temperature and Heat Flow." The presence of large volumes of warm ground water in the area makes it probable, therefore, that the spring water has acquired həat by conduction and by mixing with ground water having temperatures as high as $30^{\circ} \mathrm{C}$ to $40^{\circ} \mathrm{C}$. The effects of these processes would probably establish a mixing line for spring 14 on the silica-enthalpy diagram originating at some position above point $\mathrm{A}$ and trending roughly parallel to the line through spring 34 . The mixing line would probably include sample 16, a highly mixed water from a spring located about 2 miles south of Fisher Hot Spring. Spring 16 has a surface 
temperature of $38^{\circ} \mathrm{C}$ and a flow of $1-2 \mathrm{gal} \mathrm{min}^{-1}$. The reservoir equilibration point could range from near $M 1$ to $\mathrm{P}$, depending on the point of origin and the displacement of spring 14 due to conductive heating. The indicated temperature of equilibration is in the range of $165^{\circ} \mathrm{C}$ to $175^{\circ} \mathrm{C}$ and the fraction of high-temperature water in the mixture is about 0.10 . A similar trend would appear on the chloride-enthalpy diagram (fig. 17).

General confirmation of the mixing relations for Fisher Hot Spring and other thermal waters is provided by the boron-enthalpy diagram (fig. 18), which shows a configuration similar to that of the chlorideenthalpy relation. However, plots of the relation between boron and other major ions (not presented in this report) show much more scatter than similar plots using chloride. In particular, samples 1, 14, and 34 have exceptionally low boron-chloride ratios that have the effect of displacing these samples on the boronenthalpy graph (fig. 18) from the positions they occupy on the chloride-enthalpy graph (fig. 17). If boron concentrations in these samples are low as the result of near-surface reactions with clay minerals, for example, adjustments for these losses applied to the boron concentrations in figure 18 for samples 1,14 , and 34 would bring them into conformity with the relations on the chloride-enthalpy graph. The boron-enthalpy graph thus provides a partly independent confirmation of the chloride relations and supports the concept of highenthalpy, low-concentration mixed waters for Fisher Hot Spring and spring $16{ }^{2}$

In spring 16 , thermal water apparently has mixed with local water to produce ratios of major ions that are similar in all important respects to those in spring 14 (table 7). Most of these ratios contrast strongly with those in three shallow low-temperature wells in the area $(6,8,15)$. The relatively high temperature of spring 16 probably reflects the high ambient temperatures in the area rather than a large component of thermal water, however. The fraction of thermal water may be only about 0.05 , as determined by the probable mixing line with background water of elevated temperature and dissolved solids concentration. The mixing water could readily be derived from waters like those in wells 6,8 , and 15 by conductive heating and reequilibration, with consequent decreases in calcium, magnesium, bicarbonate, and sulfate relative to sodium and chloride.

Relations among major ionic constituents of the thermal waters and mixing calculations based on these

\footnotetext{
${ }^{2}$ The anomalously high concentration of boron in spring 46 may be the result of waterrock interaction as the spring water flows about $0.6 \mathrm{mi}$ through the siliceous sinter terrace to its outlet: Chemical analysis of the sinter shows that it contains 700 parts per million by weight of boron
}

relations tend to reinforce the hypothesis of lowtemperature mixing for the waters of Fisher Hot Spring and spring 16 . These springs consistently fall on or near the trends of chloride versus silica and chloride versus bicarbonate in figures 7,8 , and 9 . They also have consistent ratios to the positions of spring 11 and the hotter waters in these diagrams. Mixing trends are believed to provide good evidence that waters in positions along well-defined trends probably reflect similar origins and are mixed with chemically similar waters.

From these arguments, and as a check on the relationship between the silica-enthalpy and chlorideenthalpy graphs, it may be assumed that, if the water of spring 14 is derived from a reservoir between points $\mathrm{P}$ and $\mathrm{M} 1$, having a temperature of $170^{\circ} \mathrm{C}$, a chloride concentration of about $215 \mathrm{mg} \mathrm{L}^{-1}$ (fig. 17) and a silica concentration of about $175 \mathrm{mg} \mathrm{L}^{-1}$ (fig. 16) the position of this reservoir water should fall along the mixing trend in the silica-chloride graph (fig. 7). The point labeled $\mathbf{P}^{\prime}$ in figure 7 is consistent with this hypothesis and with the positions of the Crump geyser samples. The graphs based on chloride concentration, silica concentration, and enthalpy thus demonstrate fairly consistent relationships among waters in the two major thermal areas of Warner Valley.

The mixing hypothesis described above indicates that the temperature of equilibration for the thermal component of Fisher Hot Spring is at least $170^{\circ} \mathrm{C}$. The apparent equilibration temperature of $123^{\circ} \mathrm{C}$ indicated by the quartz geothermometer (table 9 ) is, of course, in agreement with the proposed mixing formula derived from the silica-enthalpy graph. The identical temperature obtained from the magnesium-corrected $\mathrm{Na}-\mathrm{K}-\mathrm{Ca}$ geothermometer could be fortuitous, and the uncorrected temperature of $169^{\circ} \mathrm{C}$ may be correct. The addition of magnesium during mixing at shallow depths would not have changed the ratios used in the $\mathrm{Na}-\mathrm{K}-\mathrm{Ca}$ geothermometer.

To summarize the conclusions for the Fisher Hot Spring and Crump geyser areas, the reservoir waters indicated by mixing models for the two areas have similar, although not identical, temperatures and concentrations of dissolved constituents. Apparent equilibration temperatures range from a mimimum of $165^{\circ} \mathrm{C}$ for Fisher Hot Spring to $173^{\circ} \mathrm{C}$ for Crump geyser. Chloride concentrations may be in the range 215 to 240 $\mathrm{mg} \mathrm{L}^{-1}$ and silica concentrations may be in the range 165 to $190 \mathrm{mg} \mathrm{L}^{-1}$. On the basis of ratios to silica and chloride, dissolved solids concentrations could range from 900 to $1,150 \mathrm{mg} \mathrm{L}^{-1}$. The apparent differences between the reservoirs supplying the two areas may be commensurate with the uncertainties inherent in the mixing models and hence should not be taken as con- 


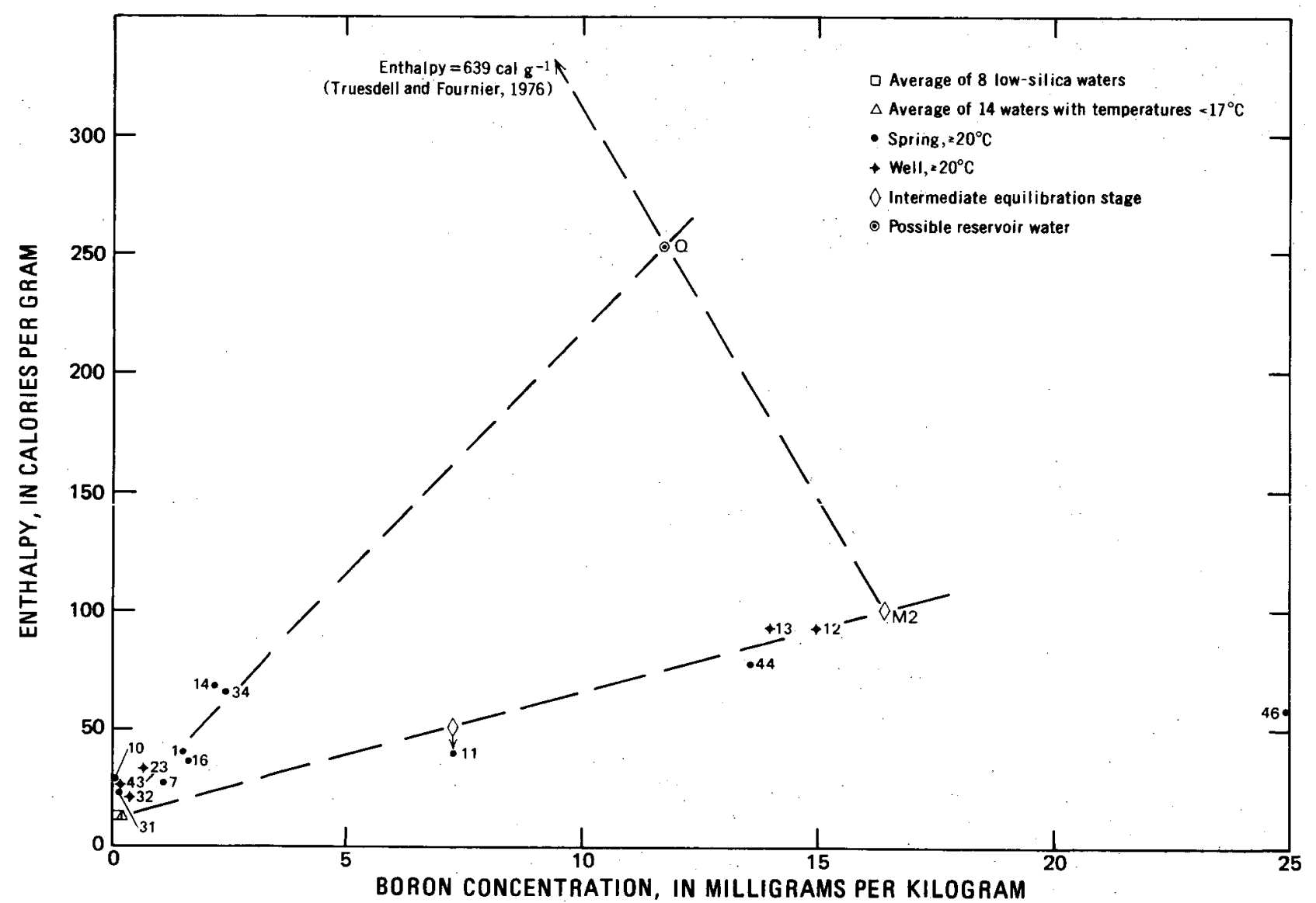

园

FIGURE 18.-Graph of boron concentration versus enthalpy in waters having surface temperatures $>30^{\circ} \mathrm{C}$. 
clusive evidence of discontinuity between the reservoirs.

Graphs of the isotope concentrations $\delta^{18} \mathrm{O}$ and $\delta \mathrm{D}$ versus chloride have proven useful in clarifying the relations among thermal waters and thermal reservoirs in Yellowstone Park and Long Valley (Truesdell and others, 1977; Fournier and others, 1979). This approach, applied to waters of Warner Valley (figs. 19 and 20), adds little to the information previously discussed, largely because of the scarcity of boiling waters and uncertainties concerning the reservoir characteristics. However, the relations depicted in figures 19 and 20 agree with the mixing models for the Warner Valley waters with only minor inconsistencies.

The partition of oxygen-18 and deuterium that would result from single-stage boiling from a reservoir at $220^{\circ} \mathrm{C}$ (point Q) to a separation temperature of $96^{\circ} \mathrm{C}$ (surface boiling temperature in Warner Valley) fixes one outside limit for the thermal waters, while the mixing line between the equilibration point and an assumed cold-water point fixes the remaining boundary (Truesdell and others, 1977). Point Q represents a possible, but not probable, origin for the thermal waters in a deep, high-temperature reservoir. The evidence for such a reservoir is discussed at the end of this section of the report.

The scatter of deuterium concentrations in the lowtemperature waters (table 8) makes it difficult to select a low-temperature origin point, and spring 18 was rather arbitrarily chosen for this point in figure 19. In figure 20 , the average $\delta^{18} \mathrm{O}$ value in 14 cold waters was chosen as the point of origin, A, although the high concentrations of oxygen- 18 in springs 14 and 16 probably require a cold-water point considerably enriched in oxygen-18. This fact is not incompatible with the proposed mixing of thermal water with moderately hightemperature water to produce the water of Fisher Hot Spring and spring 16 . The probable error in the determination of oxygen- 18 and deuterium concentrations is

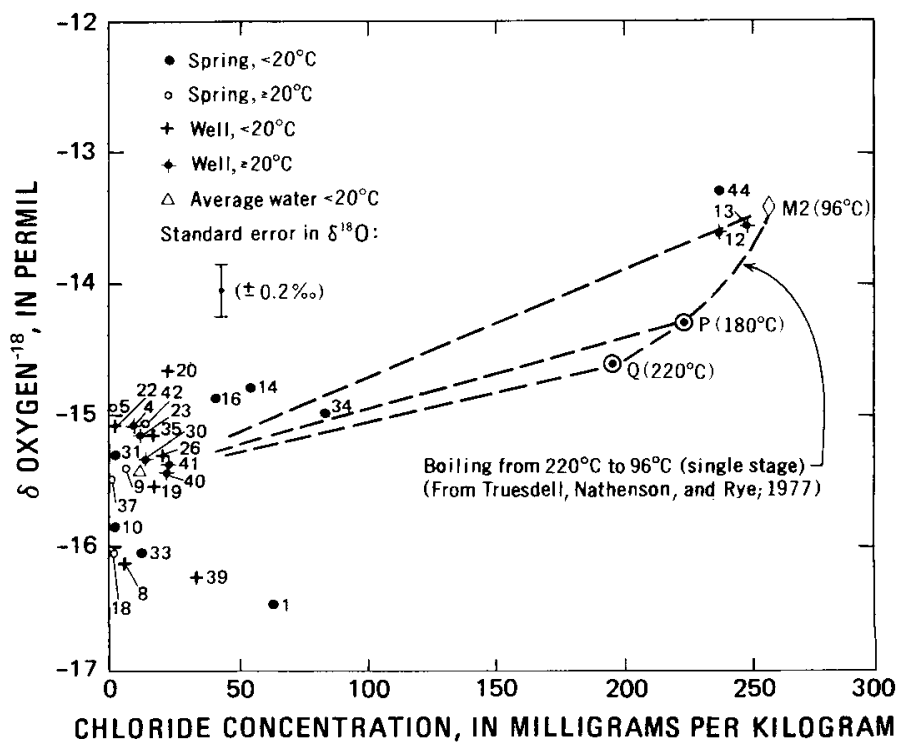

FIGURE 20.-Graph of chloride concentration versus $\delta^{18} \mathrm{O}$ in ground water, showing a single-stage boiling curve between $220^{\circ} \mathrm{C}$ and $96^{\circ} \mathrm{C}$.

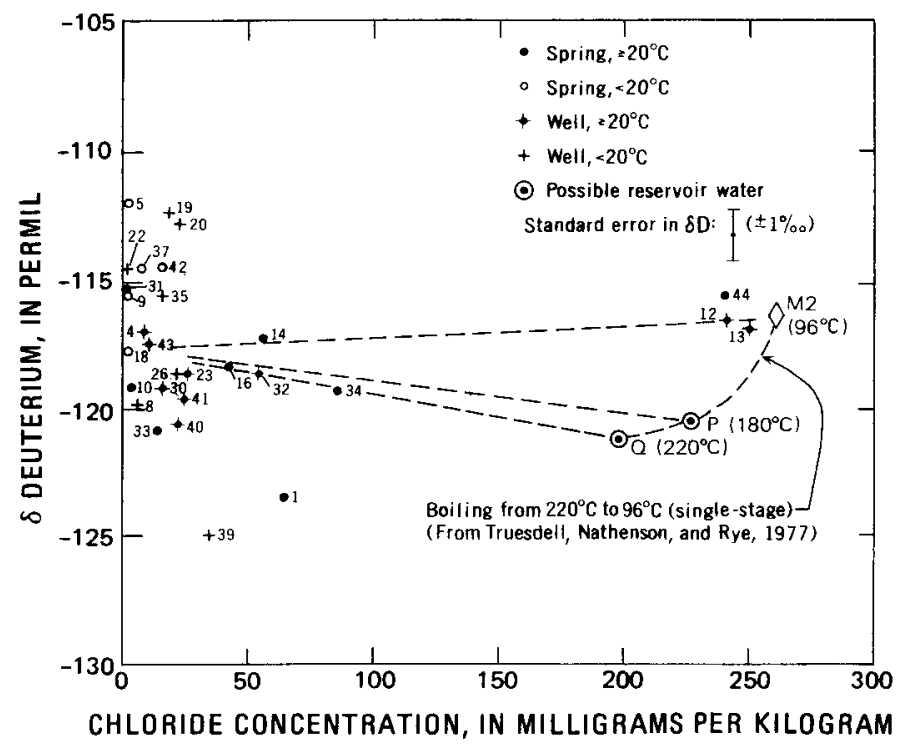

FIgURE 19.-Graph of chloride concentration versus $\delta \mathrm{D}$ in ground water, showing a single-stage boiling curve between $220^{\circ} \mathrm{C}$ and $96^{\circ} \mathrm{C}$. 
rather large; despite this fact, the correlation of figures 19 and 20 with the silica-enthalpy and chlorideenthalpy graphs is fairly good.

\section{OTHER THERMAL WATERS}

Spring 34 is located at the base of a tilted fault block at the south end of Warner Valley. The rate of flow is difficult to determine but is estimated to be in the range of 3 to 5 gallons per minute. The surface temperature is $66^{\circ} \mathrm{C}$ and the apparent temperatures of equilibration are $109^{\circ} \mathrm{C}$ and $105^{\circ} \mathrm{C}$ respectively, according to the chalcedony and the magnesium-corrected $\mathrm{Na}-\mathrm{K}-\mathrm{Ca}$ geothermometers.

Spring 34 is probably a mixed water having fractions of cold water of 0.68 and 0.66 calculated from the silica-enthalpy and chloride-enthalpy graphs, respectively. The graphs of isotope concentration versus chloride concentration (figs. 19 and 20) also suggest that the water has formed by direct mixing of local ground water with reservoir water. Fractions of cold water calculated by assuming mixing from point $P$ in figures 20 and 21 range from 0.62 and 0.66 , depending on the point chosen for the cold-water component. It should be noted, however, that quantitative determisations from figures 19 and 20 are highly dependent on the chloride concentrations and hence add little independent support to the determinations based on the chloride-enthalpy relation.

The interpretations given above suggest that the geothermal regime at the south end of Warner Valley in the vicinity of spring 34 is similar to the regime postulated for the areas north of Adel. Several aspects of the chemistry of spring 34 cloud this picture, however.

Spring 34 has high concentrations of sulfate, bicarbonate, and fluoride and low concentrations of calcium and boron relative to other thermal waters. The $\mathrm{pH}$ is fairly low (7.2) and the deuterium concentration is significantly depleted relative to concentrations in more typical thermal waters. Finally, the concentration of dissolved solids in this water is too high to fit any of the mixing relations utilized above.

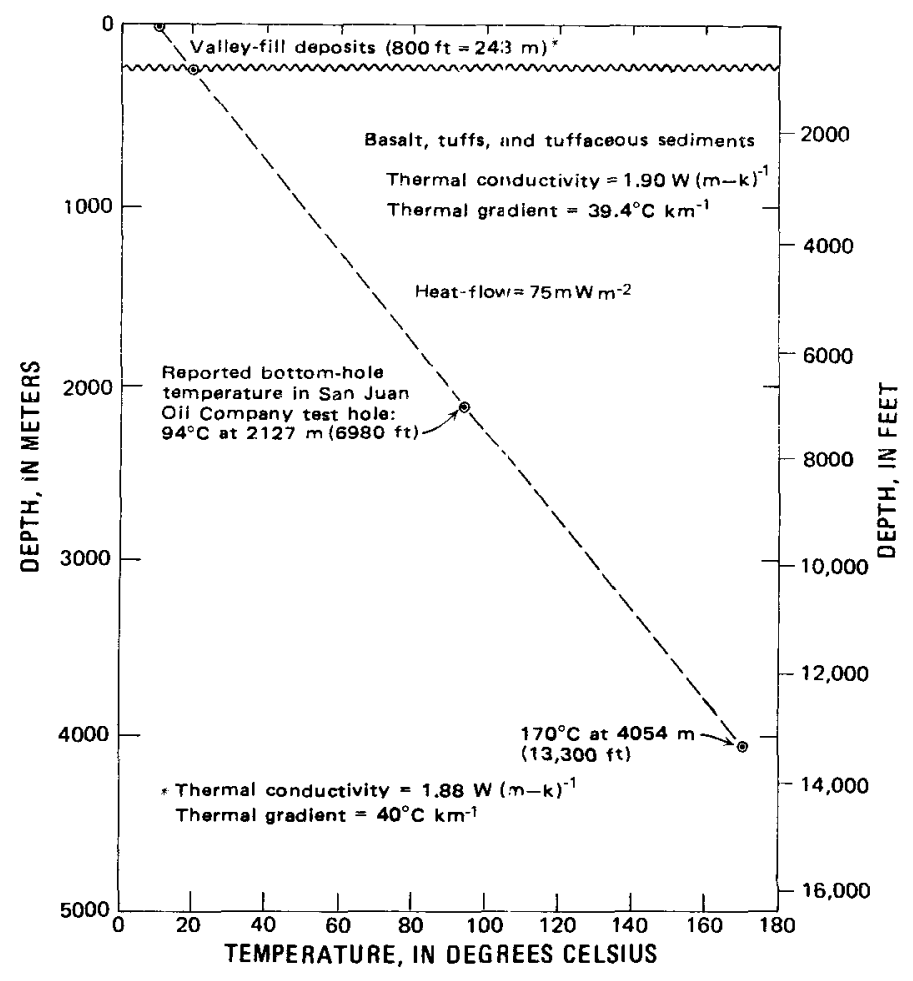

FigURe 21.-Hypothetical profile of normal temperature versus depth in Warner Valley. 
Ratios of several major ions, $\mathrm{Ca} / \mathrm{Mg}, \mathrm{Cl} / \mathrm{Mg}$, and $\mathrm{Cl} / \mathrm{Na}$ (table 7), indicate a fairly close relationship between spring 34 and the hotter thermal waters. The silica-chloride relation in figure 7 also confirms the probable origin of the thermal component of spring 34 in hot water similar to that of Fisher Hot Spring and Crump geyser. Ratios that are sensitive to lowtemperature equilibration, such as $\mathrm{Ca} / \mathrm{Mg}$ and $\mathrm{Cl} /\left(\mathrm{HCO}_{3}+\mathrm{CO}_{3}\right)$, are closer to those observed in two samples from a deep test hole located near the south end of the valley (samples 40 and 41). The samples from depths below 492 feet in this test hole have higher concentrations of bicarbonate, sulfate, and fluoride than shallower ground waters and they may represent a type of water that occurs in the Tertiary volcanic sediments that underlie the valley floor. The positions, in figure 4, of samples from wells in bedrock or deep wells in the valley-fill deposits tend to support this conclusion. (See samples 4, 19, 23, 32, 40, 41, and 43.) Ground water of this type is depleted in deuterium and probably contains little or no tritium; it may represent old water recharged during pluvial times from high altitudes.

On the basis of the chemical composition and mixing models, therefore, it is believed that the thermal waters of spring 34 and other warm springs at the south end of the valley originally equilibrate at a temperature of $170^{\circ}-180^{\circ} \mathrm{C}$. Mixing with local ground water adds high concentrations of fluoride, sulfate, bicarbonate, and dissolved solids while ratios of chloride to silica remain on the mixing trend observed for more typical thermal waters. The fraction of cold water in the mixture may range from 0.65 to 0.71 or more, depending on the selection of a low-temperature point for the local ground water. The sulfate-oxygen geothermometer (table 9) apparently confirms a hightemperature equilibration for this water $\left(179^{\circ} \mathrm{C}\right)$, but the reliability of this geothermometer is questionable when it is applied to a mixture presumably containing large amounts of low-temperature sulfate.

Another thermal water, that of Antelope Hot Spring on Hart Mountain (1), does not fit any of the models thus far described. The sample is a low-enthalpy, high-silica, sodium bicarbonate water that is not clearly related to other thermal waters of the area.

Antelope Hot Spring appears far from the mixing trends established by other thermal waters in figures 7,8 and 9 , although the separate trend that could be deduced from the graph of figure 7 is not substantiated by the graphs of figures 8 and 9 . This water contains low concentrations of deuterium and oxygen-18 which place it outside the field established by other thermal waters on the graphs of isotope-chloride relations (figs. 19 and 20 ). The quartz and Na-K-Ca geothermometers are in close agreement at a temperature of about $168^{\circ} \mathrm{C}$, but the high concentration of magnesium $(2.5$ $\mathrm{mg} \mathrm{L}^{-1}$ ) suggests that the corrected Na-K-Ca temperature of $87^{\circ} \mathrm{C}$ may be applicable.

A comparison of the silica-enthalpy and chlorideenthalpy graphs (figs. 16 and 17) suggests that the water has acquired excess silica relative to the chloride concentration. Computer calculations of phase equilibria (Kharaka and Barnes, 1973) lend support to this assumption by showing that the water is supersaturated with respect to amorphous silica at its measured temperature.

Molal ratios of $\sqrt{\mathrm{Ca}} / \mathrm{Na}, \mathrm{Na} / \mathrm{K}$, and $\mathrm{Cl} / \mathrm{SO}_{4}$ are similar to ratios in the waters of Crump geyser and Fisher Hot Spring, but other ratios are highly dissimilar (table 7). Most ratios suggest that the water is highly mixed and has reequilibrated with shallow ground water at low temperature.

Several hypotheses provide partial explanations for the origin of Antelope Hot Spring. First, the water may have cooled conductively from the reservoir indicated by the quartz and $\mathrm{Na}-\mathrm{K}-\mathrm{Ca}$ geothermometers at about $170^{\circ} \mathrm{C}$. If so, the low chloride concentration in relation to silica and dissolved solids concentrations must be accounted for in some other way. A second explanation is based on the single-stage boiling and mixing relationship determined by the mixing line through spring 1 on the silica-enthalpy graph (fig. 16). This process would require that the thermal component of the mixture originate in a reservoir at about $215^{\circ} \mathrm{C}$. The data do not clearly rule out such a high-temperature reservoir, and this possibility is discussed further in the summary of this section of the report. It may be significant, however, that the mixing line from $\mathrm{R} 1$ in figure 16 closely follows the equilibrium curve for amorphous silica solubility and that the spring water is supersaturated with respect to amorphous silica.

The most probable explanation for the characteristics of Antelope Hot Spring involves conductive cooling, mixing, and the solution of silica during the cooling and mixing process. Many combinations of these processes would fit the available data and none of them is susceptible to convincing proof.

The position of sample 1 on the chloride-enthalpy diagram (fig. 17) is probably the most reliable indicator of the relation of this water to other thermal waters in the area. On this diagram, sample 1 falls above the mixing line for the Crump geyser waters. In view of the isolated location of spring 1, its high altitude, and the absence of any other thermal water on Hart Mountain, it seems probable that this water cools conductively from a position even farther above the Crump geyser mixing trend and that this water is not necessarily derived from the reservoir that supplies the Crump 
geyser water. Furthermore, the water that recharges Antelope Hot Spring is probably derived from the same high-altitude sources that recharge the shallow aquifers on Hart Mountain. The result is seen in the unusually low concentrations of oxygen-18 and deuterium in the spring water (figs. 10, 19, and 20).

The exceptionally high silica concentration in spring 1 is probably derived from Tertiary tuffaceous sedimentary rocks that underlie and are incorporated in the volcanic dome of Hart Mountain (fig. 3). Corroborative evidence for this view is provided by the chemical composition of Valet Spring, a cold-water spring located about 1 mile north of Antelope Hot Spring on Hart Mountain. The silica concentration in Valet Spring is $66 \mathrm{mg} \mathrm{L}^{-1}$, the highest concentration measured in a cold spring, and the water also contains higher concentrations of sodium, bicarbonate, sulfate, and dissolved solids than other cold springs in or near the valley.

The water of Antelope Hot Spring probably rises in the permeable zone of a major fault intersection (fig. 3 ), cools conductively, and mixes with local ground water. The reservoir supplying the spring has a temperature of at least $87^{\circ} \mathrm{C}$, as indicated by the magnesiumcorrected Na-K-Ca geothermometer (table 9), but the temperature could be considerably higher if possible mixing relations on the chloride-enthalpy graph are considered.

The equilibration temperature for Antelope Hot Spring probably cannot be estimated on the basis of available data. Despite agreement between the quartz conductive and uncorrected $\mathrm{Na}-\mathrm{K}-\mathrm{Ca}$ geothermometers, neither of these is believed to be reliable in this instance. The quartz geothermometer is almost certainly erroneous if the chloride concentration is, as assumed, a valid indicator of mixing. The Na-K-Ca geothermometer is probably erroneous if, as assumed, the thermal water originates from and mixes with low-temperature ground water from Hart Mountain. When the Na-K-Ca geothermometer is applied to the water of spring 45 , for example, calculated equilibration temperatures are $191^{\circ} \mathrm{C}$ and $63^{\circ} \mathrm{C}$, respectively, for the uncorrected and magnesium-corrected geothermometers. These temperatures do not differ greatly from those indicated for spring 1 , suggesting that even the magnesium-corrected value may not be a reliable indicator of equilibration temperature in the hot spring.

The last of the nine samples having temperatures greater than $30^{\circ} \mathrm{C}$ is number 23 , obtained from a well of unknown depth located along the west boundary fault about 2 miles south of Adel. The well is known to be old and is used only rarely for stock watering. As a consequence, there is some doubt about the reliability of the chemical data.

The data from well 23 demonstrate many of the complexities inherent in the determination of chemical relations in low-temperature waters. Sample 23 falls near the trends for Fisher Hot Spring and spring 34 in figure 17 (chloride-enthalpy); it falls near the trend for Crump geyser waters in figures 5 (chloride-fluoride) and 16 (silica-enthalpy); and it is on the trend with Antelope Hot Spring and low-temperature waters from cleep wells in figure 7 (silica-chloride). Ratios of major ions in this water (table 7) are similarly varied.

The chloride concentration should be one of the more reliable indicators for well 23 , and in relation to this constituent, both temperature and silica concentration are higher than expected. The water shares significant characteristics, however, with other deep well waters from the southern part of the valley and also with water from the thermal spring 34 .

On the basis of the ratios $\mathrm{Cl} / \mathrm{Na}, \mathrm{Cl} / \mathrm{SO}_{4}, \mathrm{Cl} /\left(\mathrm{HCO}_{3}+\right.$ $\left.\mathrm{CO}_{3}\right), \mathrm{Ca} / \mathrm{Mg}$, and $\mathrm{Na} / \mathrm{K}$ (table 7 ), and the chlorideenthalpy and $\delta \mathrm{D}$-chloride diagrams (figs. 17 and 19), the water is assumed to be a combination of typical high-temperature water mixed with a large fraction of shallow ground water having higher than normal tempierature and silica concentration. The relations are probably similar to those in spring 34 with additional complexities of unknown origin.

The most probable interpretations of the chemical relations and geothermometers in the waters of Warner Valley lead to the conclusion that the thermal components of these waters equilibrate in similar reservoirs at temperatures of at least $170^{\circ} \mathrm{C}$ and attain their surface temperatures and compositions largely by conductive cooling and mixing.

Adiabatic cooling with steam separation is believed $t_{1}$ be minimal for even the hotter waters. At the altitude of Crump geyser (4,500 feet), water in an unconfined aquifer could boil only at depths less than about 230 feet if the temperature were as high as $170^{\circ} \mathrm{C}$. Data from wells 12 and 13 at this location indicate that temperatures were about $124^{\circ} \mathrm{C}$ and $127^{\circ} \mathrm{C}$ at depths of 120 and 660 feet, respectively, suggesting that the shallow water is far below temperatures required for boiling under normal hydrostatic heads. If the mixing relations deduced for these wells are valid, they imply that a reasonably good hydraulic connection exists between the reservoir water and the shallow waters, and this suggests that the reservoir waters could not boil at great depths. The implausibility of extensive boiling thus favors the conductive cooling hypothesis for the Crump geyser waters and the concept of deep mixing for the remaining thermal areas.

The silica-enthalpy and chloride-enthalpy relations for the Warner Valley thermal waters can be inter- 
preted to imply the existence of a deep parent reservoir from which the $170^{\circ} \mathrm{C}$ waters of shallower reservoirs are derived. In figures 16 and 17 , mixing lines for two springs, Antelope Hot Spring and Fisher Hot Spring, can be projected to equilibration points that represent such a deep, hot reservoir. One line through Fisher Hot Spring (14) projects to a reservoir at $\mathrm{Q}$ on the chlorideenthalpy graph, and a line through Antelope Hot Spring (1) projects to a similar point (Q1) on the silicaenthalpy graph.

Although highly speculative, point $Q$ on the chloride-enthalpy graph could be a point of origin for all thermal waters in the area. According to this hypothesis, reservoir water at $Q$ cools adiabatically to M2 and mixes with cold water to form the waters of the Crump geyser area $(12,13$, and 44$)$. At intermediate points, M1 and R, the water mixes directly with cooler water to form the waters of spring 34 and spring 1 . Water from $Q$ also mixes directly with waters of lower temperature to produce the mixture at N2, from which waters of the Fisher Hot Spring area are derived by further mixing. (The point N2 was established as the end point of a possible mixing trend for Fisher Hot Spring in fig. 16).

Inspection of the silica-enthalpy graph (fig. 16) shows that if the water of Antelope Hot Spring is derived from a high-temperature reservoir, the reservoir water could cool adiabatically from Q1 to R1 and then mix with recharge water, $A$, to produce the observed silica concentration in the spring. The equilibration point equivalent to $\mathrm{R} 1$ on the chloride-enthalpy graph could be anywhere along the $96 \mathrm{cal} \mathrm{gm}^{-1}$ steam separation line. If it is placed, as shown in figure 17, at a point where the mixing fractions are identical to those for R1-1-A on the silica diagram, it falls conveniently near the extension of a boiling curve through N2. The reservoir equilibration point equivalent to $\mathrm{Q} 1$ would then presumably occur at the $218 \mathrm{cal} \mathrm{gm}^{-1}$ enthalpy level along the boiling curve as shown.

The hypothesis outlined above requires the existence of two intermediate reservoirs beneath Warner Valley, one having high silica and low chloride concentrations and the other having the reverse. An occurrence of this kind seems implausible. Furthermore, the relations proposed for Antelope Hot Spring are not substantiated by the isotope-chloride graphs (figs. 20 and 21) or by calculated mixing fractions. The unreliability of indications from Antelope Hot Spring has been discussed above, and the evidence from this spring should probably be given very little weight in conclusions concerning a high-temperature reservoir. The mixing line through Fisher Hot Spring to point $Q$ also cannot be substantiated by the isotope-chloride graphs. If the most probable of several possible mixing lines for
Fisher Hot Spring is accepted, the equilibration point falls close to M1 and the evidence for a reservoir at $Q$ vanishes.

Additional evidence supporting the concept of a high-temperature reservoir are the equilibration temperatures estimated by means of the sulfate-oxygen geothermometer (McKenzie and Truesdell, 1977) for springs 11,44 , and 46 and well 12 in the Crump geyser area (table 9). Apparent temperatures of sulfateoxygen equilibration range from $200^{\circ} \mathrm{C}$ to $219^{\circ} \mathrm{C}$ in these waters for the conductive heat-loss model. The consistency of the estimated temperatures is remarkable in view of the inclusion of spring 11 , a highly mixed water having a measured temperature of $40^{\circ} \mathrm{C}$. The maximum temperature, $219^{\circ} \mathrm{C}$, is consistent with the indications of the chloride-enthalpy graph (fig. 17).

The most damaging argument against the evidence provided by the silica-enthalpy and chloride-enthalpy diagrams is the extremely low probability that water from a high-temperature reservoir has cooled adiabatically in accordance with the boiling curves suggested in figures 16 and 17 . There is no evidence, for example, that the waters represented by possible equilibration points N2, M1, or P are derived from or are heated by steam that would have separated from a deep reservoir. There are no fumaroles in the Crump geyser area that would indicate steam separation, although this lack does not preclude the condensation of steam in the shallow ground water. However, ratios of chloride to boron, which would be expected to indicate deep boiling, show evidence only of normal heating of meteoric water. Other constituents, such as fluoride, arsenic, and lithium, similarly give no indications of extensive boiling.

There would be no need to invoke adiabatic cooling, however, if fluid from a deep high-temperature reservoir were assumed to ascend and cool conductively and then reequilibrate at shallower depths in a reservoir represented by points in the vicinity of M4 in figure 17 . All thermal waters in the area could be derived from a point near M4 by the same means proposed above for an origin at point $\mathrm{Q}$. The silica and $\mathrm{Na}-\mathrm{K}-\mathrm{Ca}$ geothermometers thus would represent the reequilibration temperatures, whereas the slow-responding sulfateoxygen would continue to indicate the temperature of the deeper reservoir.

Many uncertainties still surround the application of the sulfate-oxygen geothermometer. A discussion by Nehring and Mariner (1979) shows, for example, that thermal waters may dissolve "fossil" sulfate from minerals formed at higher temperatures, thus giving higher sulfate geothermometer temperatures than chemical geothermometers. This explanation was advanced to account for discrepancies in geothermome- 
ters in the Klamath Falls area (Sammel, 1980). On the other hand, Nehring and Mariner present evidence to show that some high-temperature waters precipitate silica at concentrations greater than about $200 \mathrm{mg} \mathrm{L}^{-1}$, thereby causing the discrepancies between the silica and sulfate geothermometers.

A third possible hypothesis, therefore, is that the precipitation of silica has resulted in erroneously low temperatures from the quartz geothermometer. In this case, the reservoir would be deeper than estimated and the thermal fluids would be assumed to cool conductively to temperatures at which the mixing relations proposed previously would apply. Some of the mixing proportions would be incorrect in this case but the general relationships would still be applicable.

The significance of these several hypotheses for strategies of exploration and development is discussed in the final section of this report. In view of the uncertainties, however, the occurrence of a deep hightemperature reservoir in Warner Valley is speculative and has an essentially unknown probability.

\section{CONCEPTUAL MODELS OF THE GEOTHERMAL SYSTEM}

\section{HEAT-FLOW CONSTRAINTS ON THE DEPTH OF FLUID CIRCULATION}

Thermal waters of the Warner Valley area are believed to originate in a deeply-circulating hot-water system. The chemical compositions of the thermal waters show no evidence that the waters have been in contact with magma or have been heated by steam rising from a magma chamber. The chemical evidence is thus in accord with the data of MacLeod, Walker, and McKee (1975), who conclude that silicic domal masses or magma chambers in this region are probably 8 or 9 million years old and would have cooled to ambient temperatures by the present time.

Geothermometers and mixing models indicate that temperatures of equilibration for the thermal components of the waters are at least $170^{\circ} \mathrm{C}$ prior to mixing. The depth at which this temperature would occur in a steady-state conductive regime beneath Warner Valley is estimated to be at least 13,000 feet. The assumptions used for this estimate are depicted in figure 21 and are described as follows: average heat flow in the valley is 75 milliwatts per square meter $\left(\mathrm{mW} \mathrm{m}^{-2}\right)$; thermal conductivity in the valley-fill deposits is 1.88 watts per meter kelvin $\left(\mathrm{W}(\mathrm{m} \bullet \mathrm{K})^{-1}\right)$; the average depth of the valley fill in the area north of Adel is 800 feet, based on depth to bedrock in the U.S. Geological Survey test hole, MC1, and on a similar depth reported in a San Juan Oil Co. test hole near Adel; thermal conductivity in the underlying Tertiary basalt and tuffaceous sedi- ments is $1.9 \mathrm{~W}(\mathrm{~m} \cdot \mathrm{K})^{-1}$, which is lower than the concluctivity in a dense basalt but which may be a reasonable value for the thin flows, tuffs, and tuffaceous sediments that underlie the valley.

The depth of 13,000 feet $(4 \mathrm{~km})$ is calculated with the further assumption that the average thermal conductivity in the bedrock remains constant with depth. Characteristics of the bedrock reported in logs of the San Juan Oil Company well show no overall change to a depth of 7,500 feet, but if deeper rocks were to have higher thermal conductivities as the result of greater densities, the depth to the $170^{\circ} \mathrm{C}$ horizon would be correspondingly increased. Calculated gradients of about $39^{\circ} \mathrm{C} \mathrm{km}^{-1}$ in the bedrock and $40^{\circ} \mathrm{C} \mathrm{km}^{-1}$ in the valleyf.ll deposits produce a temperature-depth relation that is in close agreement with a reported bottom-hole temperature of $94^{\circ} \mathrm{C}$ at a depth of 6,980 feet in the San Juan Oil Co. test hole (figure 21).

The requirement that thermal waters circulate to a depth of at least $4 \mathrm{~km}$ in order to attain the estimated reservoir temperature implies that the flow probably occurs in major boundary faults. Evidence that major faults are active and are possible conduits for groundwater flow to such depths is provided by the Adel earthquake swarm which had focal centers at depths ranging from $2 \mathrm{~km}$ to nearly $13 \mathrm{~km}$ and averaging 9 km (Schaff, 1976).

It is clear from geometric considerations that if thermal water is confined to a nearly vertical fault plane, it will not capture the vertical conductive heat flux in the crust as efficiently as if the water were spread laterally in a horizontal aquifer. Numerical models developed by M. L. Sorey for the Grass Valley, $\mathrm{Nev}$., geothermal system show, for example, that for some fault-controlled hydrothermal systems in the Basin and Range province, rates of heat absorption by meteoric water circulating down a fault are insufficient to raise fluid temperatures to known or inferred reservoir temperatures within reasonable depths of circulation (Welch, and others, 1981). In addition to vertical flow in the fault, lateral circulation is needed in order to capture a sufficient amount of heat. In the absence of lateral circulation, the meteoric recharge water would cool the adjacent rocks.

In order to estimate whether or not lateral circulation might be required in the Warner Valley faultsystem, flow rates were estimated for all known thermal springs and wells in Warner Valley and the flow rates of the thermal components, presumably derived from the $170^{\circ} \mathrm{C}$ reservoir, were calculated on the basis of proportions derived from mixing models. The sum of the flow rates of thermal springs and wells in Warner Valley is approximately 7.5 kilograms per second ( $\mathrm{kg}$ $\mathrm{s}^{-1}$ ) and the total rate of flow from the thermal reser- 
voir is approximately $2 \mathrm{~kg} \mathrm{~s}^{-1}$ ). Total thermal discharge at the land surface above a base temperature of $10^{\circ} \mathrm{C}$ is calculated to be $1.8 \times 10^{6}$ watts (W).

If the estimated mass flow from the reservoir is assumed to be replaced by recharge water circulating down the faults, calculations based on numerical models show that, at a depth of $4 \mathrm{~km}$, this circulation would lower the rock temperature about $20^{\circ} \mathrm{C}$ below that which would exist in the absence of fluid circulation (Welch and others, 1981). The assumed boundary conditions include a $70^{\circ} \mathrm{C}$ dip of the fault planes on either side of the valley and circulation to $4 \mathrm{~km}$. The dip of the faults is taken as the smaller of two estimates: $70^{\circ} \mathrm{C}$ estimated by Peterson $(1959)$, and $80^{\circ} \mathrm{C}$ estimated by Schaff (1976) on the basis of seismic data from the Warner Valley earthquake swarm of 1968. The smaller estimate is slightly more favorable for effective heat transfer. Half of the total flow is assumed to occur on each side of the valley, and the horizontal length of fault through which flow occurs is assumed to be $4 \mathrm{~km}$ on each side. If downflow occurs over greater lengths of the fault or if fluid circulation has not continued for sufficient time to establish a thermal steady state, resulting temperatures at depth in the fault conduit would be correspondingly higher.

This analysis indicates that if the total throughflow of the thermal water is approximately $2 \mathrm{~kg} \mathrm{~s}^{-1}$, the hydrothermal system in Warner Valley could consist largely of water circulating within the boundary faults to a depth of little more than $4 \mathrm{~km}$. The storage of both water and heat in the system would be extremely small in this case. The existence of a more extensive reservoir is not ruled out, however, and this possibility is discussed in the final section of this report.

Numerical simulations by Sorey (1978) further suggest that thermal waters having flow rates similar to those estimated for the Warner Valley springs would cool appreciably by conduction prior to reaching the surface. Conductive cooling at a flow rate of $2 \mathrm{~kg} \mathrm{~s}^{-1}$ might lower the temperature as much as $75^{\circ} \mathrm{C}$ from a reservoir temperature of $170^{\circ} \mathrm{C}$. These results are qualitatively confirmed by calculations, reported by Truesdell, Nathenson, and Rye (1977), which indicate that flows less than $1.7 \mathrm{~kg} \mathrm{~s}^{-1}$ at $200^{\circ} \mathrm{C}$ would cool to below boiling temperature in a vertical ascent of $4 \mathrm{~km}$. Thermal water arising from such a depth would have to flow at rates greater than $15 \mathrm{~kg} \mathrm{~s}^{-1}$ in order to maintain reservoir temperatures.

CONSTRAINTS BASED ON CHEMICAL DATA AND MIXING MODELS

The results of the numerical models must be reconciled with chemical data which are partly ambiguous (for example, the geothermometers) but which have a generally satisfying consistency (for example, the isotope data and the mixing calculations). Indications based on ratios of major ions, isotope concentrations, and mixing relations can probably be taken at face value as evidence of a high-temperature reservoir. Silica-concentrations in the hotter waters are consistent with this evidence and indicate that the temperature is at least $170^{\circ} \mathrm{C}$.

Two factors may mitigate the supposed effects of conductive cooling. The flow rate from the reservoir could be as much as double the estimated rate, and much of the flow could be dispersed within the valleyfill deposits. The large volumes of heated ground water known to exist in the Crump geyser and Fisher Hot Spring areas are evidence of this dispersion. Higher flow rates would decrease the temperature loss in the upflowing thermal water and the higher ambient temperatures in the mixing zones would further increase the final temperature of the mixing water.

The differing influences of these factors are probably involved to some extent in the temperature differences observed between the Crump geyser area and the Fisher Hot Spring area. It is likely, for example, that the flow system is not symmetric as postulated in the heat-loss model described above. Discharge on the west side of the valley could be as much as twice the discharge on the east side, thereby accounting in part for the temperature differences between the two areas.

On the west side of the valley, thermal water from the reservoir probably ascends and cools conductively in several conduits within the boundary fault. The flow rate may be in the range 1 to $3 \mathrm{~kg} \mathrm{~s}^{-1}$. Near the base of the valley-fill deposits, the continuity of the channels is broken and the water spreads and mixes with local ground water. Clear evidence for the hot saline water in this zone is seen in the resistivity data described in a previous section of the report.

The water may reequilibrate to some extent in this mixing zone and attain the cation ratios that, in the $\mathrm{Na}-\mathrm{K}-\mathrm{Ca}$ geothermometer, indicate a temperature of $152^{\circ} \mathrm{C}$. Silica concentrations and dissolved solids concentrations remain high, however, in the slowly circulating hot water. Vertical permeabilities in this zone are probably low and one half or more of the hot water spreads laterally through the valley-fill deposits. The remainder ascends to the surface through the conduits that supply the thermal springs in this area. As previous sections of this report have shown, some springs contain highly mixed water (samples 7,10 , and 11 , for example) while other springs and two wells (springs 44 and 46 and wells 12 and 13) tap only slightly mixed water that retains most of the characteristics acquired in the thermal reservoir.

In the Fisher Hot Spring area, the cooling and mixing relations are not entirely clear, but much of the 
evidence points toward a reservoir temperature of $170^{\circ} \mathrm{C}$ or more. The reservoir could be the one that supplies the Crump geyser waters or it could be hydraulically unconnected and have slightly lower concentrations of chloride and slightly higher silica concentrations than the Crump geyser reservoir. The resolution of mixing diagrams for these waters is not sufficiently precise to permit distinctions of this sort to be made. It seems fairly certain, however, that the reservoir water mixes directly with local warm waters to produce the water of Fisher Hot Spring and spring 16.

There is at present no evidence to indicate a large mixing zone in the deeper valley-fill deposits beneath Fisher Hot Spring similar to the zone inferred beneath Crump geyser. Heat-flow holes give clear evidence, however, of a zone of lateral spreading that extends to depths of at least several hundred feet. The areal extent of this zone has not been well defined but is at least several square miles.

Conditions similar to those in the Fisher Hot Spring area are also believed to exist at the south end of Warner Valley, where thermal waters having temperatures of $170^{\circ} \mathrm{C}$ or more appear to mix directly with local warm waters. The area may differ from the northern areas in that much of the warm water may exist in a fractured fault block that dips into the valley and forms its southern boundary. Little else can be deduced from the data available at this time, and additional data collected in the area by a private exploration company may refine or alter these conclusions in the future.

\section{RESERVOIR CHARACTERISTICS}

Discussions in this report referring to the geothermal reservoir in Warner Valley have thus far assumed only that circultion occurs along fault planes to depths sufficient to attain indicated reservoir temperatures. Available data neither confirm nor deny the possibility that circulation also occurs in a direction perpendicular to the fault plane in a laterally extensive volume of rock.

Some evidence supports this possibility. The great enrichment of oxygen-18 in the reservoir waters relative to recharge waters could require that the thermal waters percolate through large volumes of permeable rock outside the fault zone, especially if leaching has depleted the oxygen-18 in the rocks of the fault conduits. The similarity of thermal waters on opposite sides of the valley (if the mixing models are valid) may also support the concept of a laterally extensive reservoir.

If a more extensive reservoir exists, the narrow range of reservoir temperatures indicated by the geothermometers and mixing models for waters on both sides of the valley may imply that the reservoir rocks have a fairly small vertical thickness. The known stratigraphy of the area also implies that permeable strata at great depths are likely to be thin, perhaps confined to alternating interflow zones in basaltic rocks.

If rock temperatures are assumed to range from $170^{\circ} \mathrm{C}$ at the top of the reservoir to $180^{\circ} \mathrm{C}$ at the bottom, this temperature difference would probably occur over a vertical distance of no more than a few hundred meters, assuming that vertical convective flow in the reservoir is minimal. For the calculations that follow, a minimum reservoir thickness of 200 meters $(650 \mathrm{ft})$ and a probable maximum thickness of 500 meters $(1,600 \mathrm{ft})$ are assumed.

It is convenient to assume that the reservoir is confined to the rocks that lie between the main boundary faults, although it may be equally probable that a major reason for the occurrence of the thermal waters at this location is a fortuitous juxtaposition of permeable rocks on both sides of the two faults. The first possibility seems much the more likely of the two, however, and is assumed to be the case in the following discussion.

It may also be assumed that the reservoir supplying Crump geyser and Fisher Hot Spring is confined to a 9-mile length of the valley between Pelican Lake and Hart Lake. This assumption is based on the lack of thermal manifestations to the north and south of this area and on data from the Geological Survey test holes MC1 and OK1 and the San Juan Oil Co. well east of Adel, all of which show less than normal temperatures at their respective total depths of 885,522 , and 7,500 feet.

By projecting an assumed $70^{\circ}$ dip of the boundary faults in the area underlain by the reservoir, the average width of the reservoir between the faults at a depth of 13,000 feet is determined to be 3.2 miles and the area of the reservoir is, therefore, about $29 \mathrm{mi}^{2}\left(75 \mathrm{~km}^{2}\right)$. For assumed thicknesses of 650 feet $(200 \mathrm{~m})$ and 1,600 feet $(500 \mathrm{~m})$, the reservoir volume is calculated to be $3.6 \mathrm{mi}^{3}$ $\left(15 \mathrm{~km}^{3}\right)$ and $9 \mathrm{mi}^{3}\left(38 \mathrm{~km}^{3}\right)$, respectively.

Utilizing the International System of Units for ease in comparison of results, a porosity of 0.10 is assumed in the reservoir rocks and volumetric specific heat is assumed to be 2.7 joules per cubic centimeter per degree Celsius $\left(\mathrm{J} \mathrm{cm}^{-3}{ }^{\circ} \mathrm{C}^{-1}\right)$. Volumetric heat above a base temperature of $10^{\circ} \mathrm{C}$ stored in the reservoir is then calculated to be $6.5 \times 10^{18} \mathrm{~J}$ for the $200 \mathrm{~m}$ thickness and $1.6 \times 10^{19} \mathrm{~J}$ for the 500-meter thickness. Applying the 25 percent recovery factor used by Nathenson and Niuffler (1975), recoverable thermal energy is estimated to be $1.6 \times 10^{18} \mathrm{~J}$ and $4 \times 10^{18} \mathrm{~J}$ for the two thicknesses of reservoir assumed. 
Several additional calculations can be made to serve as rough checks on the heat and mass balances implied by the preceeding analysis. For example, assuming that normal heat flow through the valley-fill deposits is $0.075 \mathrm{~W} \mathrm{~m}^{-2}$, the total conductive heat flow in the area underlain by the reservoir $\left(117 \mathrm{~km}^{2}\right)$ is calculated to be $8.8 \times 10^{6} \mathrm{~W}$. The calculated convective heat discharge at or near land surface, $1.8 \times 10^{6} \mathrm{~W}$, is, therefore, about one-fifth of the conductive heat flow. The difference between the values is sufficiently. large to ensure an adequate conductive heat-flow base from which to derive the convective discharge. The convective discharge is large enough, however, to account for a probable small deficit in the measured heat flows in the central and northern parts of the valley. It may also account, in part, for the lower than normal thermal gradients observed in the San Juan Oil Company well and the Geological Survey test holes MC1 and OK1.

A second calculation may be made in order to estimate mass flow rates and apparent permeabilities in the reservoir rocks. For this calculation, it is assumed that mass discharge from the thermal reservoir is double the estimated flow at the surface, or 4 kilograms per second $\left(\mathrm{kg} \mathrm{s}^{-1}\right)$. Corrected for density at $170^{\circ} \mathrm{C}$, this becomes 4.7 liters per second $\left(\mathrm{L} \mathrm{s}^{-1}\right)$. The hydraulic gradient in the reservoir is assumed to be 0.005 , comparable to the near-surface gradient estimated for regional ground-water flow. For the width and range of thicknesses assumed for the reservoir, the apparent permeability is calculated to be in the range 0.10 to 0.15 feet per day $\left(\mathrm{ft}^{-1}\right.$ ), which, corrected to surface temperature, is about $2 \times 10^{-2}$ to $5 \times 10^{-2} \mathrm{ft} \mathrm{d}^{-1}$.

It could also be assumed that as little as one-fourth or as much as three-fourths of the total flow in the reservoir results in upward flow in the conduits, but in all cases, the calculated permeabilities remain in a range that appears reasonable when compared with published data from other areas. (See, for example, $6 \times$ $10^{-3} \mathrm{ft} \mathrm{d}^{-1}$ for welded tuffs in Nevada (Davis and De Wiest, 1966, p. 339), $6 \times 10^{-3} \mathrm{ft} \mathrm{d}^{-1}$ for welded tuffs and tuffaceous sediments in Long Valley, Calif. (Sorey and others, 1978), and $2.5 \times 10^{-4} \mathrm{ft} \mathrm{d}^{-1}$ for moderately dense Hawaiian basalts (Davis, 1969, p. 65). All of the parameters assumed for the above calculations have extremely large uncertainties, and the fair agreement with a few published data is not intended to imply any degree of reliability in the results. The calculations do no more than indicate that the assumptions used may be reasonable ones.

At the south end of Warner Valley in the large tilted fault block and the adjacent valley-fill deposits, the reservoir may have an area of about $8 \mathrm{mi}^{2}\left(21 \mathrm{~km}^{2}\right)$. On the basis of the chemical data, the reservoir may be assumed to occur at the same depth as the northern reservoir. For the same range of reservoir thicknesses the stored heat is calculated to be about $3.2 \times 10^{18} \mathrm{~J}$ and the recoverable energy is about $8 \times 10^{17} \mathrm{~J}$.

The combined recoverable thermal energy in the Crump geyser, Fisher Hot Spring, and south Warner areas is estimated to be about $5 \times 10^{18} \mathrm{~J}$. The estimate is based, as described above, on a single reservoir supplying Crump geyser and Fisher Hot Spring and a separate reservoir supplying springs at the south end of the valley. The estimate is regarded as a probable maximum.

The probable minimum heat content in the Warner Valley systems is calculated as heat stored only in the major faults and associated fractured rocks in the fault zones. The total heat stored in faults adjacent to Crump geyser, Fisher Hot Spring, and spring 34 at the south end of Warner Valley could be as small as $5 \times 10^{16} \mathrm{~J}$. This calculation includes a total fault length of 25 kilometers, a depth interval of 500 meters and a faultzone thickness of 10 meters; porosity and heat capacity are the same as assumed for the reservoir calculations above, and the heat stored in the upflow conduits is ignored. The recovery factor for such a system is unknown but could be assumed to be comparable to that calculated for the extended reservoir systems. Thus, recoverable thermal energy for the fault-restricted system may be about $1 \times 10^{16} \mathrm{~J}$.

Additional geothermal resources occur in Coleman Valley and Big Valley, where warm springs or wells indicate probable low-temperature systems. The areas covered by this report may also contain undiscovered resources. The additional geothermal energy in these areas is expected to be small.

Unless the geothermal heat in a reservoir can be tapped by wells within economic drilling limits, the thermal energy represents an accessible resource base rather than a resource, to use the terminology employed by Muffler and Guffanti (1979). The recoverability of the deep reservoir water in Warner Valley is uncertain. However, the hot water that can be obtained from shallow wells penetrating the fault zones or the valley-fill deposits represents a low-tomoderate-temperature resource which could be readily utilized at the present time.

Much of the thermal energy stored in the Crump geyser and Fisher Hot Spring areas is available to wells less than 300 meters deep within the valley-fill deposits. In each of these areas, the volume of sedimentary deposits containing water at temperatures of $100^{\circ} \mathrm{C}$ or more may be about one-half $\mathrm{km}^{3}$. If porosity and volumetric specific heat in the valley-fill deposits are conservatively assumed to be the same as in the bedrock, the total thermal energy above a base temperature of $10^{\circ} \mathrm{C}$ is calculated to be about $1 \times 10^{17} \mathrm{~J}$ for 
each area. Assuming 25 percent recovery, the total recoverable energy in the sedimentary deposits of the upper valley may be about $5 \times 10^{16} \mathrm{~J}$. In the absence of comparable data from the south end of Warner Valley, no estimate has been made for this area.

Thermal energy may be recoverable from the deep reservoirs in Warner Valley by drilling into the fault zones in the Crump geyser and Fisher Hot Spring areas. Wells tapping the fault zones should encounter water at temperatures intermediate between the reservoir temperature and the boiling temperature at land surface (approximately $96^{\circ} \mathrm{C}$ ). Estimates based on the numerical model results of Sorey (1978) indicate that thermal water ascending and conductively cooling in a fault plane should retain a temperature of at least $155^{\circ} \mathrm{C}$ at a depth of 2 kilometers for the flow rates and boundary conditions applicable to the Crump geyser area. At a depth of 1 kilometer, the temperature should be at least $140^{\circ} \mathrm{C}$, and at 0.6 kilometer, about $130^{\circ} \mathrm{C}$.

If the flow is confined to a cylindrical conduit, the temperatures at any depth would be considerably higher than those estimated for the fault-plane model. Estimates of the temperature decrease caused by conductive cooling in cylindrical conduits and fault planes based on analytical solutions of Nathenson, Urban, and Diment (1979) and Sorey (1978) indicate that thermal upflow in the principal geothermal areas of Warner Valley is probably restricted to lengths of the faults that may approach the dimensions of a cylindrical conduit. The analytical results show, for example, that reservoir water having a flow rate of $2 \mathrm{~kg} \mathrm{~s}^{-1}$ would cool to about $96^{\circ} \mathrm{C}$ at land surface in either a cylinder of small dimension or a fault plane less than $400 \mathrm{~m}$ in length. Greater lengths of fault surface would permit cooling to much lower temperatures than are actually observed in the Crump geyser area, while flow rates much greater than those estimated would apparently result in higher temperatures than those observed near land surface and would imply that considerable boiling must occur at shallow depths.

The implications of these conclusions for geothermal exploration and development are clear. Water can probably be obtained at temperatures of $100^{\circ} \mathrm{C}$ or more by wells penetrating the unconsolidated deposits to depths of 200 to 300 meters within a kilometer or two of the Crump geyser and Fisher Hot Spring areas. Water approaching the estimated reservoir temperature (at least $170^{\circ} \mathrm{C}$ ) is probably available only to wells that tap the fault conduits close to the hot springs.

As the foregoing calculations show, water should be available at high temperatures in the upflow conduits within acceptable drilling depths. If a permeable conduit were to be tapped by a pumped well, the decrease in pressure caused by pumping would be transmitted to the reservoir and the flow rate would increase. The result would be an increase in the discharge temperature. Although discharge temperatures would eventually decline somewhat under long-term pumping as the rocks adjacent to the conduits reequilibrated, the final steady-state temperature would be greater than the temperature initially encountered at any given depth.

If the sulfate-oxygen geothermometer correctly indicates the presence of a reservoir having a temperature of $220^{\circ} \mathrm{C}$, the two most probable conceptual models for the system are (1) a deep high-temperature reservoir that supplies a shallower reservoir in which the thermal waters reequilibrate, and (2) a deep hightemperature reservoir from which the thermal waters ascend to the surface and cool conductively, some of them mixing with cooler waters at fairly shallow depths.

In terms of present-day exploration and developrnent, case 1 would probably not differ in any practical way from the situation discussed above which assumes the presence of only one reservoir having a temperature of $170^{\circ} \mathrm{C}$ to $180^{\circ} \mathrm{C}$. In either situation, drilling costs would probably preclude drilling into the reservoir and development would occur by tapping thermal conduits above the $170^{\circ} \mathrm{C}$ reservoir. Case 2 would differ from case 1 in making possible the withdrawal of hot water directly from the deep reservoir by tapping the upflow conduits. Thus, even though conductive cooling would still occur, temperatures obtained at given depths would be higher than those obtainable in the absence of a $220^{\circ} \mathrm{C}$ reservoir.

Temperatures attainable by tapping the fault conduits have not been estimated for any of the cases described above. Factors limiting the temperature would probably be the permeability, volume, and configuration of the reservoir or reservoirs and the permeability of the upflow conduits. Aquifer tests in exploration wells tapping the conduits could provide much-needed evidence concerning these factors.

The hydraulic system in Warner Valley is probably a relatively simple one, and stresses imposed on the system during an aquifer test should make it possible to obtain reliable estimates of the temperature, size, and hydraulic characteristics of the geothermal reservoir. These estimates, combined with additional chemical and isotopic analyses, should permit the prediction of long-term responses in the system and lead to an estimate of the economic potential of the Warner Valley geothermal resource.

\section{REFERENCES}

Arnórsson, Stefán, 1975, Application of the silica geothermometer in low temperature hydrothermal areas in Iceland: American Journal of Science, v. 275, p. 763-784. 
Bowen, R. G., and Peterson, N. V., 1970, Thermal springs and wells in Oregon: Oregon Department of Geology and Mineral Industries Miscellaneous Paper 14, 1 p.

Christiansen, R. L., and McKee, E. H., 1978, Late Cenozoic volcanic and tectonic evolution of the Great Basin and Columbia Intermontane region, in Smith, R. B., and Eaton, G. P., eds., Cenozoic tectonics and regional geophysics of the Western Cordjllera: Geological Society of America Memoir 152.

Coplen, T. B., 1976, Cooperative geochemical resource assessment of the Mesa geothermal system: Final report to the U.S. Department of the Interior, Bureau of Reclamation, IGPP-UCR-76-1, Institute of Geophysics and Planetary Physics, University of California at Riverside, $97 \mathrm{p}$.

Couch, R., and Johnson, S., 1968, The Warner Valley earthquake sequence, May and June, 1968: The Ore Bin, v. 30, no. 10, p. 191-204.

Couch, R, W., and Lowell, R. P., 1971, Earthquakes and seismic energy release in Oregon: The Ore Bin, v. 33, no. 4, p. 61-84.

Craig, H., 1961, Standard for reporting concentrations of deuterium and oxygen-18 in natural waters: Science, v. 133, p. 1833.

Davis, S. N., 1969, Porosity and permeability of natural materials, in DeWiest, R. J. M., ed., Flow through porous media: New York, Academic Press, p. 54-89.

Davis, S. N., and DeWiest, R. J. M., 1966, Hydrogeology: New York, John Wiley, $463 \mathrm{p}$.

Donath, F. A., 1962, Analysis of basin-range structure, SouthCentral Oregon: Geological Society of America Bulletin, v. 73, p. $1-16$.

Downs, Theodore, 1956, The Mascall fauna from the Miocene of Oregon: California University, Department of Geological Science Bulletin, v. 31 , no. 5, p. 199-354

Ellis, A. J., 1970, Quantitative interpretation of chemical characteristics of hydrothermal systems: U.N. Symposium on the Development and Utilization of Geothermal Resources, Pisa, 1970 in Geothermics, Special Issue 2, p. 516-528.

Evernden, J. F., Savage, D. E., Curtis, G. H., and James, G. T., 1964, Potassium-argon dates and the Cenozoic mammalian chronology of North America: American Journal of Science, v. 262, p. 145198.

Fournier, R. O., 1973, Silica in thermal waters: laboratory and field investigations: International Symposium on Hydrogeochemistry and Biogeochemistry, Proceedings, Tokyo, 1970, Washington, D.C., The Clarke Company, p. 122-139.

- 1977, Chemical geothermometers and mixing models for geothermal systems: Geothermics, v. 5, p. 41-50.

Fournier, R. O., and Potter, R. W., 1978, A magnesium correction for the Na-K-Ca chemical geothermometer: U.S. Geological Survey Open-File Report 78-486, 24 p.

Fournier, R. O., and Rowe, J. J., 1966, Estimation of underground temperatures from the silica content of water from hot springs and wet steam wells: American Journal of Science, v. 264, no. 9, p. 685-697.

Fournier, R. O., and Truesdell, A. H., 1970, Chemical indicators of subsurface temperature applied to hot spring waters of Yellowstone National Park, Wyoming, U.S.A., in U.N. Symposium on Development and Utilization of Geothermal Resources, Pisa, 1970: Geothermics, Special Issue 2, p. 529-535.

_ 1973, An empirical Na-K-Ca geothermometer for natural waters: Geochimica et Cosmochimica Acta, v. 37, p. 1255-1275.

1974, Geochemical indicators of subsurface temperaturePart II, Estimation of temperature and fraction of hot water mixed with cold water: U.S. Geological Survey Journal of Research, v. 2, no. 3, p. 263-270.

Fournier, R. O., Sorey, M. L., Mariner, R. H., and Truesdell, A. H., 1979, Chemical and isotopic prediction of aquifer temperatures in the geothermal system at Long Valley, California: Journal of Volcanology and Geothermal Research, v. 5, p. 17-34.

Fuller, R. E., 1931, The geomorphology and volcanic sequence of Steens Mountain in southeastern Oregon: Washington University Geology Publication, v. 3, no. 1, p. 1-130.

Greene, R. C., Walker, G. 'W., and Corcoran, R. E., 1972, Geologic map of the Burns quadrangle, Oregon: U.S. Geological Survey Miscellaneous Geologic Investigations map I-680, scale $1: 250,000$,

Gregory, D. I., and Martinez, R. J,, 1975, Audio-magnetotelluric apparent resistivity maps, Warner Valley, Oregon: U.S. Geological Survey Open-File Report 75-652, 4 sheets.

Hem, J. D., 1970, Study and interpretation of the chemical characteristics of natural water: U.S. Geological Survey Water-Supply Paper 1473, p. 176-178.

Hurr, R. T., 1966, A new approach for estimating transmissibility from specific capacity: Water Resources Research, v. 2, no. 4, p. $657-664$.

Kharaka, Y. K., and Barnes, Ivan, 1973, SOLMNEQ: Solutionmineral equilibrium computations: U.S. Geological Survey Computer Contribution, National Technical Information Service PB 215-899, $81 \mathrm{p}$.

Klein, C. W., and Koenig, J. B., 1977, Interpretation of analytical results, thermal and non-thermal waters, lava plateaus region of northeastern California and southern Oregon: Second workshop on sampling geothermal effluents, Environmental Protection Agency, Proceedings, p. 166-173.

Langbein, W. B., 1961, Salinity and hydrology of closed lakes: U.S. Geological Survey Professional Paper 412, 20 p.

Larson, E. E., 1965, The structure, stratigraphy and paleomagnetics of the Plush area, southeastern Lake County, Oregon: Ph. D. dissertation, University of Colorado, $166 \mathrm{p}$.

McKenzie, W. F., and Truesdell, A. H., 1977, Geothermal reservoir temperatures estimated from the oxygen isotope compositions of dissolved sulfate and water from hot springs and shallow drillholes: Geothermics, v. 5, p. 51-61.

MacLeod, N. S., Walker, G. W., and McKee, E. H., 1975, Geothermal significance of eastward increase in age of upper Cenozoic rhyolitic domes in southeastern Oregon: Second United Nations Symposium on Development and Use of Geothermal Resources, San Francisco, 1975, Proc., p. 465-474.

Mahon, W. A. J., 1970, Chemistry in the exploration and exploitation of hydrothermal systems, in U.N. Symposium on Development and Utilization of Geothermal Resources, Pisa, 1970: Geothermics, Special Issue 2, p. 1310-1322.

Mariner, R. H., Presser, T. S., Rapp, J. B., and Willey, L. M., 1975, The minor and trace elements, gas and isotope compositions of the principal hot springs of Nevada and Oregon: U.S. Geological Survey Open-File Report, $27 \mathrm{p}$.

Mariner, R. H., Rapp, J. B., Willey, L. M., and Presser, T. S., 1974, The chemical composition and estimated minimum thermal reservoir temperatures of selected hot springs in Oregon: U.S. Geological Survey Open-File Report, $27 \mathrm{p}$.

Merriam, J. C., 1901, A contribution to the geology of the John Day Basin (Oregon): California University, Department of Geology Bulletin, v. 2, no. 9, p. 269-314.

1910, Tertiary mammal beds of Virgin Valley and Thousand Creek in northwestern Nevada, pt. 1, Geologic history: California University, Department of Geology Bulletin, v. 6, no. 2, p. 21-53.

Muffler, L. J. P., and Guffanti, Marianne, 1979, Introduction, in Muffler, L. J. P., ed., Assessment of geothermal resources of the United States-1978: U.S. Geological Survey Circular 790, p. 1-7.

Nathenson, Manuel, and Muffler, L. J. P., 1975, Geothermal re- 
sources in hydrothermal convection systems and conductiondominated areas, in White, D. F., and Williams, D. L., eds., Assessment of geothermal resources of the United States-1975: U.S. Geological Survey Circular 726, p. 104-121.

Nathenson, Manuel, Urban, T. C., and Diment, W. H., 1979, Approximate solution for the temperature distribution caused by. flow up a fault and its application to temperatures measured in a drillhole at Raft River Geothermal Area, Cassia County, Idaho: Geothermal Resources Council Transactions, v. 3, p. 447-480.

Nehring, N. L., and Mariner, R. H., 1979, Sulfate-water isotopic equilibrium temperatures for thermal springs and wells of the Great Basin: Geothermal Resources Council, Transactions, v. 3, p. 485-488.

Nehring, N. L., Mariner, R. H., White, L. D., Huebner, M. A., Roberts, E. D., Haron, Karen, Bowen, P. A., and Tanner, Lane, 1979, Sulfate geothermometry of thermal waters in the western United States: U.S. Geological Survey Open-File Report 79 $1135,11 \mathrm{p}$.

Newcomb, R. C., 1958, Yonna formation of the Klamath River Basin, Oregon: Northwest Science, v. 32, no. 2, p. 41-48.

Pearson, F. J., and Truesdell, A. H., 1978, Tritium in the waters of Yellowstone National Park: Short papers of the 4th International Conference, Geochronology, Cosmochronology, Isotope Geology, 1978: U.S. Geological Survey Open-File Report 78-701, p. $327-329$.

Peterson, N. V., 1959, Lake County's new continuous geyser: The Ore Bin, v. 21 , no. 9 , p. $83-88$.

Phillips, K. N., and Van Denburgh, A. S., 1971, Hydrology and geochemistry of Abert, Summer, and Goose Lakes, and other closed-basin lakes in south-central Oregon: U.S. Geological Survey Professional Paper 502-B, 86 p.

Plouff, Donald, and Conradi, Arthur, Jr., 1975, Gravity and magnetic profiles and maps, Crump Geyser Area, Oregon: U.S. Geological Survey Open-File Report 75-346, 2 p., 3 sheets.

Renick, B. C., 1930, The petrology and geology of a portion of Malheur County, Oregon: Journal of Geology, v. 38, p. 387-496.

Richins, W. D., 1974, Earthquake swarm near Denio, Nevada, February to April, 1973: M.S. Thesis, University of Nevada, Reno.

Russell, R. J., 1928, Basin Range structure and stratigraphy of the Warner Range, northeastern California: California University Publications in Geological Sciences, v. 17, no. 11, p. 387-496.

Sammel, E. A., 1980, Hydrogeologic appraisal of the Klamath Falls geothermal area, Oregon: U.S. Geological Survey Professional Paper 1044-G, 45 p.

Sass, J. H., Kennelly, J. P., Jr. Wendt, W. E., Moses, T. H., and Ziagos, J. P., 1979, In-situ determination of heat flow in unconsolidated sediments: U.S. Geological Survey Open-File Report 79-593, $73 \mathrm{p}$.

Schaff, S. C., 1976, The 1968 Adel, Oregon, earthquake swarm: M. A. Thesis, University of Nevada, Reno, $63 \mathrm{p}$.

Sorey, M. L., 1978, Numerical modeling of liquid geothermal systems: U.S. Geological Survey Professional Paper 1044-D, 25 p.

Sorey, M. L., Lewis, R. E., and Olmsted, F. H., 1978, The hydrothermal system of Long Valley Caldera, California: U.S. Geological Survey Professional Paper 1044-A, 60 p.
Theis, C. V., 1963, Estimating the transmissibility of a water-table aquifer from the specific capacity of a well, in Bentall, Ray, compiler, Methods of determining permeability, transmissibility, and drawdown: U.S. Geological Survey Water-Supply Paper 1536-I, p. 332-336.

T'rauger, F. D., 1950, Factual ground-water data in Lake County, Oregon: U.S. Geological Survey Open-File Report in cooperation with Office of Oregon State Engineer, 287 p.

Truesdell, A. H., and Fournier, R. O., 1976, Calculations of deep temperatures in geothermal systems from the chemistry of boiling spring waters of mixed origin: Second United Nations Symposium on the Development and Use of Geothermal Resources, San Francisco, 1975, Proc., p. 837-844.

Truesdell, A. H., Nathenson, Manuel, and Rye, R. O., 1977, The effects of subsurface boiling and dilution on the isotopic compositions of Yellowstone thermal waters: Journal of Geophysical Research, v. 82 , no. 26, p. 3694-3704.

U.S. Geological Survey, 1976, Water resources data for Oregon, Water year 1975: U.S. Geological Survey Water-Data Report OR-75-1.

Van Winkle, W., 1914, Quality of the surface waters of Oregon: U.S. Geological Survey Water-Supply Paper 363, 137 p.

Walker, G. W., and Repenning, C. A., 1965, Reconnaissance geologic map of the Adel Quadrangle, Lake, Harney, and Malheur Counties, Oregon: U.S. Geological Survey Miscellaneous Geologic Investigations map I-446, scale 1:250,000.

Walker, G. W., and Swanson, D. A., 1968, Summary report on the geology and mineral resources of the Poker Jim Ridge and Fort Warner areas of the Hart Mountain National Antelope Refuge, Lake County, Oregon: U.S. Geological Survey Bulletin 1260-M, $22 \mathrm{p}$.

Wallace, R. E., 1946, A. Miocene mammalian fauna from Beatty Buttes, Oregon: Carnegie Institution of Washington Publication 551, p. 113-134.

Weide, D. L., 1974, Postglacial geomorphology and environments of the Warner Valley-Hart Mountain Area, Oregon: Ph. D. dissertation, University of California, Los Angeles, Department of Geography, $160 \mathrm{p}$.

Welch, A. H., Sorey, M. L., and Olmsted, F. H., 1981, Hydrothermal system in southern Grass Valley, Pershing County, Nevada: U.S. Geological Survey Open-File Report (in preparation).

Wells, F. G., and Peck, D. L., 1961, Geologic map of Oregon west of the 121st meridian: U.S. Geological Survey Miscellaneous Geologic Investigations map I-325, scale 1:500,000.

Whistler, J. T., and Lewis, J. H., 1916, Warner Valley and White River projects: U.S. Reclamation Service, 123 p.

White, D. E., 1968, Hydrology, activity, and heat flow of the Steamboat Springs thermal system, Washoe County, Nevada: U.S. Geological Survey Professional Paper 458-C, 109 p.

-_ 1970, Geochemistry applied to the discovery, evaluation, and exploitation of geothermal energy resources, in U.N. Symposium on the Development and Utilization of Geothermal Resources, Pisa, 1970: Geothermics, Special Issue 2, p. 58-80.

White, D. E., Muffler, L. J. P., and Truesdell, A. H., 1971, Vapordominated hydrothermal systems compared with hot-water systems: Economic Geology, v. 66, no. 1, p. 75-97. 

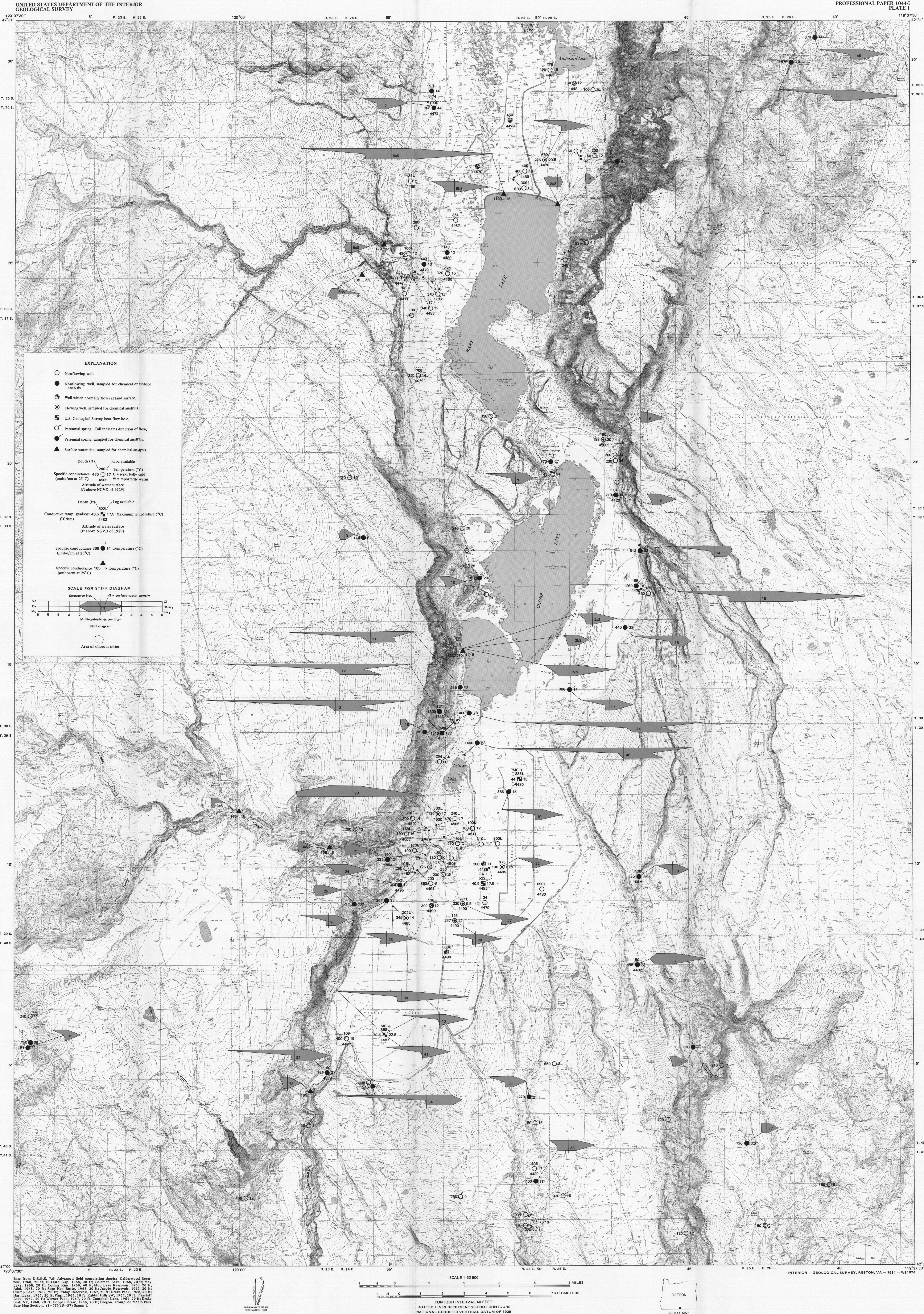